NBER WORKING PAPER SERIES

\title{
ARE BANKS PASSIVE LIQUIDITY BACKSTOPS? DEPOSIT RATES AND FLOWS DURING THE 2007-2009 CRISIS
}

\author{
Viral V. Acharya \\ Nada Mora \\ Working Paper 17838 \\ http://www.nber.org/papers/w17838 \\ NATIONAL BUREAU OF ECONOMIC RESEARCH \\ 1050 Massachusetts Avenue \\ Cambridge, MA 02138 \\ February 2012
}

The views expressed herein are those of the authors and do not necessarily reflect the position of the Federal Reserve Bank of Kansas City or the Federal Reserve System. Jacob Schak, Paul Rotilie, Thad Sieracki, Jon Christensson, and Kristen Regehr provided valuable research assistance. We are grateful to Ruth Judson for her help with the Bank Rate Monitor data. We thank Sumit Agarwal, Heitor Almeida, David Backus, Morten Bech, Lamont Black, Francisco Covas, Bob DeYoung, Bill Keeton, Michal Kowalik, Ouarda Merrouche, Chuck Morris, Wayne Passmore, Jack Reidhill, Anthony Saunders, Ken Spong, Phil Strahan, and participants at the Financial Management Association's 2011 Meeting and the Federal Reserve's "Day Ahead" 2012 Conference on Financial Markets and Institutions for helpful comments. All errors are our own. The views expressed herein are those of the authors and do not necessarily reflect the views of the National Bureau of Economic Research.

NBER working papers are circulated for discussion and comment purposes. They have not been peerreviewed or been subject to the review by the NBER Board of Directors that accompanies official NBER publications.

(C) 2012 by Viral V. Acharya and Nada Mora. All rights reserved. Short sections of text, not to exceed two paragraphs, may be quoted without explicit permission provided that full credit, including $\odot$ notice, is given to the source. 
Are Banks Passive Liquidity Backstops? Deposit Rates and Flows during the 2007-2009 Crisis Viral V. Acharya and Nada Mora NBER Working Paper No. 17838

February 2012

JEL No. E4,G01,G11,G21,G28

\begin{abstract}
$\underline{\text { ABSTRACT }}$
Can banks maintain their advantage as liquidity providers when they are heavily exposed to a financial crisis? The standard argument - that banks can - hinges on deposit inflows that are seeking a safe haven and provide banks with a natural hedge to fund drawn credit lines and other commitments. We shed new light on this issue by studying the behavior of bank deposit rates and inflows during the 2007-09 crisis. Our results indicate that the role of the banking system as a stabilizing liquidity insurer is not one of the passive recipient, but of an active seeker, of deposits. We find that banks facing a funding squeeze sought to attract deposits by offering higher rates. Banks offering higher rates were also those most exposed to liquidity demand shocks (as measured by their unused commitments, wholesale funding dependence, and limited liquid assets), as well as with fundamentally weak balance-sheets (as measured by their non-performing loans or by subsequent failure). Such rate increases have a competitive effect in that they lead other banks to offer higher rates as well. Overall, the results present a nuanced view of deposit rates and flows to banks in a crisis, one that reflects banks not just as safety havens but also as stressed entities scrambling for deposits.
\end{abstract}

Viral V. Acharya

Stern School of Business

New York University

44 West 4th Street, Suite 9-84

New York, NY 10012

and CEPR

and also NBER

vacharya@stern.nyu.edu

Nada Mora

Federal Reserve Bank of Kansas City

nada.mora@kc.frb.org 
"Citigroup representatives fanned out across San Francisco's financial district on Oct. 17, handing out fliers promoting six-month certificates of deposit with 4 percent interest rates" - Bloomberg, "Citi Squeezed in Debt Market as JPMorgan, Wells Lure Deposits" October 20, 2008.

"The fact that Washington Mutual is now owned by Chase is very positive, because they were a huge outlier on rates, "Kenneth D. Lewis, then Chairman and CEO of Bank of America, as cited in American Banker, "Deposit-Gathering Pitches Evolving Amid Upheaval", October 9, 2008.

\section{INTRODUCTION}

In financial crises of the recent past, investors often withdrew from securities markets and placed their funds into safer assets, such as U.S. Treasuries and bank deposits. During such episodes, a wide range of businesses shut out of securities markets sought to fund their operations by drawing down credit lines established with banks during normal times. Awash with funds from depositors seeking a safe haven, banks had no difficulty meeting these increased credit demands (e.g., Gatev and Strahan, 2006). Thus, banks seem to have helped avoid financial disruptions and business liquidations that would have occurred in the absence of a liquidity backstop.

In 2007-09, however, banks were themselves at the center of the financial crisis. While significant risks were present in some other financial institutions, this crisis was special in that commercial banks were much more exposed to losses than in recent past crises. Aggregate risk also sharply increased, disrupting banks' ability to diversify shocks across businesses and depositors. These two features of the crisis (and their interaction) cast doubt on the notion that banks can be taken for granted as a natural source of liquidity during financial crises. Were banks still viewed as a safe haven, and if not, how compromised was their ability to meet the demand for liquidity? And, what actions did banks take to ensure that inflows into deposit funds persisted as their funding sources were drying up?

To answer these questions, we investigate the behavior of bank deposit rates and flows during the recent financial crisis. As banks become weak or liquidity-constrained, they may seek to attract deposits by offering higher rates. ${ }^{1}$ More broadly, competition for deposits can be intense during a crisis. $^{2}$ Supporting these channels, Chart 1a shows the average deposit rates offered by failed banks and nearly failed banks (decline in stock price of $90 \%$ or more), as measured by the difference from the rates

\footnotetext{
${ }^{1}$ For example, Washington Mutual pitched above-market rates prior to its acquisition by JP Morgan Chase in 2008 as did Countrywide in 2007. See the American Banker, October 9, 2008, "Deposit-Gathering Pitches Evolving Amid Upheaval" and December 5, 2007, "Why Rate Cuts Aren't Helping on the Deposit Side".

${ }^{2}$ Indeed, there were several news reports of extensive deposit promotions despite significant cuts in the Federal funds rate during 2008 (e.g., Citibank introduced a 6-month CD offering 4\% in October 2008 compared with an average rate of $2.9 \%$ that it paid on its deposits in the third quarter). See Bloomberg, October 20, 2008, "Citi Squeezed in Debt Market as JPMorgan, Wells Lure Deposits".
} 
of non-fail banks (that is, banks that did not fail), over a one year period prior to failure, for failures occurring during the 1997-2009 period. For ease of comparison, the $x$-axis is the time to failure. ${ }^{3}$ As is evident, the weak institutions offered substantially higher $C D$ rates in the run-up to failure. For example, the differential between their 12-month $C D$ rate and that of non-fail banks crept up from 10 basis points one year prior to failure to close to 60 basis points in the last two weeks before failure (and even their checking rates edged up). Chart $1 \mathrm{~b}$ narrows the set to four prominent examples of banks and thrifts that failed (IndyMac, Washington Mutual) or nearly failed (Wachovia, Citi) in the crisis. Zooming in on these four large financial institutions, their average 12-month CD (60-month CD) differential reached 100 basis points (130 basis points).

Were institutions that later failed able to attract correspondingly greater deposit inflows? The descriptive evidence from the quarterly regulatory reports indicates that these institutions in fact lost deposits as they approached failure. Chart 2 shows that while they were able to initially maintain inflows of insured deposits, even insured deposits registered a negative growth rate in the last two quarters prior to failure (e.g., average insured deposit growth was roughly - $1 \%$ in the quarter of the institution's final regulatory filing, and similarly, uninsured deposit growth reached -2\%). A similar pattern characterized core deposits of weak institutions as these also fell five quarters prior to failure (core deposits exclude large time and foreign deposits and are commonly considered stable sources of funding).

This deposit funding pressure was not limited to banks that failed but was widespread and particularly acute in the first phase of the crisis from the ABCP "freeze" starting August 9, 2007 (as documented in Acharya, Schnabl and Suarez, 2009), until just before the Lehman failure on September 15,2008 . Although core deposits increased in the banking system by close to $\$ 800$ billion from end 2007 to early 2009 (Table 1 and He, Khang and Krishnamurthy,2010), core deposits increased by just \$90 billion up until 2008:Q2. In other words, the sharp increase in core deposits only occurred in 2008:Q3, growing by $\$ 272$ billion in just one quarter - and occurred across both large and small banks and extended to large time deposits as well (Table 1$)^{4}$

\footnotetext{
${ }^{3}$ By failures, we hereafter mean both actual and nearly failed banks (specifically, failure for the latter cases is recorded starting the first date when the 18-month return over the period 1997-2009 was worse than -90\% using daily stock return data and following Acharya, Pedersen, Philippon, and Richardson, 2010). For example, the nearfailure date for Wachovia was September 29, 2008 (coinciding with the date its acquisition was announced), and for Citi was November 20, 2008 (the U.S. government provided a package of guarantees, liquidity financing and capital on November 23).

${ }^{4}$ While banks remained heavily exposed to losses even after 2008:Q3, the jump in aggregate uncertainty following the Lehman failure and a sudden shift in the perceived riskiness of money market funds and enacted measures of
} 
The deposit funding squeeze - coupled with the wholesale funding shortage in the ABCP market - led banks to seek deposits by offering higher deposit interest rates. We document that banks offering higher rates were those most exposed to liquidity demand shocks (as measured by their unused commitments, wholesale funding dependence, and limited liquid assets), as well as with fundamentally weak balance-sheets (e.g., as measured by their non-performing loans or by subsequent failure). At the same time, large banks - enjoying implicit guarantees because of their "too-big-to-fail" status benefited from greater deposit inflows despite offering lower deposit rates, all else equal.

Importantly, we also find support for an industry equilibrium view of deposit rate policies. That is, a bank's deposit rates are not set in isolation of the behavior of other banks. Banks offer higher rates when others raise their offered rates, in particular when the bank is located in a geographic market where a large fraction of deposits belong to banks that are about to fail. This suggests a negative externality or a competitive interest-rate "contagion" from weak banks desperately scrambling for deposit funding on to safer banks. However, and consistent with an industry equilibrium view, we find that the competitive pressure on deposit rates of a bank is relieved when the bank's deposit market is concentrated or when deposits are "sticky" (seniors make up a large fraction of its population).

We conclude that it is not necessarily the case that all increases in deposit funds are the outcome of banks passively accepting funds as a safe haven. The role of the banking system as a stabilizing liquidity insurer is an active one. We end by reconciling our findings to those of Gatev and Strahan (2006) and showing that even in the period before the 2007-09 crisis when banks were relatively untouched by market turbulence, there is evidence that banks exposed to liquidity demand shocks offered higher rates in order to secure deposit inflows in times of market stress.

Our description throughout is framed around an active response by liquidity-short banks to attract funds by raising deposit rates. This view and the results are not incompatible with depositors also disciplining riskier banks by withdrawing funds and by demanding higher rates (as shown in the diagram in Chart 3, panel A and further discussed in Section 6.1 on related literature). The reason our discussion centers on banks as stressed entities is because this paper is closely related to earlier studies depicting banks as passive entities accepting flight-to-safety funds specifically in times of financial crises. Our paper directly addresses why banks exposed to liquidity demand shocks, such as banks with greater credit lines extended, may not be able to provide liquidity in a bank-centered crisis, especially one in

official support (including raising deposit insurance limits and recapitalizations) finally pushed funds into the banking system. 
which aggregate risk rises. In contrast, the depositor discipline literature is primarily interested in crosssectional bank-risk differences and does not distinguish between crises and non-crises episodes.

The rest of the paper is organized as follows: Section 2 begins with a brief review of the theory that banks can provide liquidity when financial markets and other financial institutions cannot-and why the theory might break down in a crisis. Section 3 investigates how bank fundamentals shaped deposit rates. The section begins by developing testable hypotheses for individual bank behavior when banks need funds to support increased loan demand but face deposit funding pressure. It then presents aggregate evidence showing that banks experienced increased loan demand but that deposit inflows were weak and not commensurate with lending needs, especially in the first year of the crisis. This narrative, therefore, provides support for the underlying environment assumed in our principal hypothesis, namely, that deposit funding was tight and banks had an incentive to actively manage deposit rates. The main part of section 3 provides empirical support using bank-level data. Section 4 explores how a bank's deposit rate policies depend not only on its fundamentals, but also on the deposit rates of other banks competing in similar deposit markets. Section 5 reconciles our findings with those of Gatev and Strahan (2006). Section 6 relates our findings to the existing literature. Section 7 concludes.

\section{BANKS AS LIQUIDITY PROVIDERS: THE TRADITIONAL VIEW AND ITS RECONSIDERATION}

\subsection{The rationale for banks as liquidity providers}

Banks are considered to have an important advantage over other financial institutions in providing various forms of liquidity commitments such as corporate lines of credit and demandable deposits. This advantage relates to how they resolve the liquidity management problem that arises when commitments are converted into funded loans and immediacy is demanded on deposits. As described by Kashyap, Rajan and Stein (2002), banks combine deposit-taking with loan commitments. A synergy exists between these two activities to the extent that both services require banks to hold balances of liquid assets to provide liquidity on demand to depositors as well as to credit line borrowers. In particular, banks have a natural advantage in providing liquidity if deposit withdrawals and commitment draw-downs are not correlated.

Indeed, studies have shown that during past episodes of market stress, deposit withdrawals and commitment draw-downs were negatively related (Saidenberg and Strahan, 1999; Gatev and Strahan, 2006; Gatev, Schuermann, and Strahan, 2009). For example, when the commercial paper market encountered stress, the funds that investors pulled out of this market flowed primarily into the banking 
system. As a result, deposits flowed into banks just as borrowers resorted to drawing down their bank credit lines. These papers argue that funds flow into bank deposits in times of stress because banks are viewed as safe havens due to government guarantees on deposits. ${ }^{5}$ The view that government guarantees are responsible for the deposit inflows during crises is supported by evidence that such deposit inflows did not occur prior to the FDIC's inception in 1934. Pennacchi (2006) showed that during times of tight market liquidity from 1920 to 1933, no increases in bank deposits were observed and liquidity shocks were accompanied by declines in bank loans and investments.

\subsection{Why there may be limits to banks providing liquidity in a crisis}

We argue, however, that banks may not be able to provide liquidity in every crisis. A main reason for this is that investors may question the safety of bank deposits as well, especially when banks are directly exposed to the financial crisis (as illustrated by a depositor run at IndyMac in July 2008). Most deposits are over the deposit insurance limit (over 62\% in 2007:Q2) and are not explicitly guaranteed in the event of a bank failure. This lack of guarantee can become especially important in a bank-centered crisis, when uncertainty about the condition of an individual bank may prompt depositors to run from the bank even if it turns out to be ex post fundamentally solvent. ${ }^{6}$

A second reason is that depositors may worry that the government will not provide enough resources to make them whole in the event of a bank failure (e.g., there was evidence of risk-pricing of insured deposits during the savings and loans crisis in the 1980s when the guarantor of savings and loans, the FSLIC, was approaching insolvency (Cook and Spellman, 1994)). In the recent crisis, uncertainty over the safety of insured deposits may have increased as the FDIC's reserves started to dip. By the end of 2008, the FDIC's ratio of reserves to total insured deposits had fallen to $0.4 \%$, and the Treasury did not increase its backup line of credit to the FDIC until March 2009 (see the discussion in Acharya, Santos and Yorulmazer, 2010).

A third reason considered in Acharya, Almeida and Campello (2010) is that aggregate risk may rise during a crisis. When this happens, the ability of banks to diversify or smooth shocks across

\footnotetext{
${ }^{5}$ One point of departure from Kashyap, Rajan and Stein (2002) that Gatev and Strahan (2006) take is on what drives deposit flows in times of reduced market liquidity. The thesis in Kashyap, Rajan and Stein is that the coexistence of deposits and lending is due to real benefits and is not the result of historical or contemporary regulatory distortions. That is, they do not think it is an artificial synergy resulting from deposit insurance. Gatev and Strahan reason, instead, that banks experience deposit inflows precisely because they are perceived to be safe havens. They conjecture that this is largely due to government support, both explicit through deposit insurance and implicit through expected bailouts. The two views are not necessarily orthogonal, however.

${ }^{6}$ For example, Iyer and Puri (2008) show that depositors "ran" from a fundamentally sound bank when a nearby bank failed and that deposit insurance was only partly successful at limiting outflows of insured deposits.
} 
corporations and depositors falls. In anticipation, banks may raise costs for provision of liquidity insurance, e.g., increase spreads on corporate lines of credit. And, in response to reduced bank liquidity (outside of their model), depositors may leave banks, especially those that are heavily exposed to the rise in aggregate risk and the underlying economic shock.

Other factors besides concern over bank safety and ability to provide liquidity may also contribute to weak deposit inflows for banks in a crisis. One such factor in the recent crisis was that household wealth took a hit, and households are typically the main source of deposit funds. U.S. households' net worth fell from $\$ 65.8$ trillion at the end of 2007:Q2 to $\$ 48.8$ trillion by 2009:Q1 (from falling house values and stock market declines, affecting both real estate assets and financial assets such as pension fund assets, mutual fund shares, and directly held corporate equity). ${ }^{7}$ Moreover, households faced with increased liquidity constraints may have been more likely to withdraw deposits to cover consumption needs. For example, Chakrabarti et al (2011) find that more households reported withdrawing funds from deposit accounts than having added funds; the main reasons being a need to pay for living expenses and to reduce debt.

A second important factor was that money market mutual fund accounts (MMMF) were competing deposit collectors (Pennacchi, 2006). Investors saw MMMFs as safe up until the Lehman bankruptcy and the ensuing losses and redemption demands on the Reserve Primary Fund and other funds in September 2008. Even though a large share of prime MMMFs had invested in $A B C P$, these funds did not experience losses in 2007 because of credit and liquidity guarantees to ABCP conduits from their sponsor banks (Acharya, Schnabl and Suarez, 2009; McCabe, 2010). This is also confirmed by large inflows of funds into MMMFs (exceeding inflows into deposit accounts) in 2007 and early 2008 (Federal Reserve Bulletin, 2010).

Finally, banks may also face difficulty in providing liquidity during a bank-centered crisis if wholesale funds become more difficult to raise, especially from the private sector. ${ }^{8}$ The difficulty of raising wholesale funds in a bank-centered crisis has become more relevant over time because wholesale funds have become a greater source of funds for the banking system (increasing from roughly $25 \%$ of assets in the early 1990 s to $40 \%$ in 2007 , where wholesale funds are defined as liabilities excluding core deposits).

\footnotetext{
${ }^{7}$ These figures are from the Federal Reserve's Flow of Funds Z.1 Release, Table B.100; see also Shapiro (2010).

${ }^{8}$ Evidence of banks having difficulty getting wholesale funds from the private sector in the 2007-09 financial crisis is documented by Acharya, Schnabl and Suarez (2009), Brunnermeier (2009), Kacperczyk and Schnabl (2010), and Adrian et al (2010). Afonso, Kovner and Schoar (2010) show that while the federal funds market did not entirely dry up, it was significantly stressed in the aftermath of the Lehman failure.
} 


\section{DEPOSIT RATES AND BANK FUNDAMENTALS}

This section first develops testable hypotheses for how a bank facing funding pressure is expected to actively seek deposits. In much of this discussion, banks will be assumed to be short of deposits relative to lending and other asset funding needs, theoretical motivation for which was provided in Section 2.2 and whose veracity we establish for the 2007-09 crisis in the next subsection, 3.2. We then test whether liquidity-short and fundamentally weak banks promised higher rates.

\subsection{Hypotheses}

First, banks most susceptible to funding pressure are those banks that are documented to have later failed. Therefore, in a bank-level regression capturing the relationship shown in Charts 1 and 2, we expect that banks lose deposits prior to failure (especially deposits that are not insured), that they react by raising deposit rates, and that this relationship gets stronger as the bank gets closer to failing. Specifically, the deposit rate offered by bank $i$ at time $t$ is modeled as follows:

Deposit Rate $_{i, t}=\sum_{l=0}^{L} \beta_{l}$ Fail $_{i, t+l}+$

$$
\text { bank fixed effect }_{i}+\text { time fixed effect }_{t}+\text { other controls }_{i, t}+e_{i, t},
$$

where Fail is a dummy equal to one in the period that the bank fails and 0 otherwise (the time period is quarterly when using Call Report data). Up to $L$ leads of the fail dummy are included. Other controls capture time-varying changes in a bank's local geographic market conditions such as deposit market concentration and district time trends. Standard errors are clustered at the bank level. More detail on the regressions is provided in Section 3.3 and the Appendix. We test Hypothesis 1: $\beta_{l}>0$. And $\beta_{0}>\cdots>\beta_{L}$.

Second, if bank deposit funding was tight during the crisis, we expect that banks differed in their need for additional funding and that depositors were also discriminating between banks. While most banks did not fail, there was nonetheless considerable variation in a bank's vulnerability to the risk of illiquidity or of insolvency. Therefore, more liquid banks and banks more likely to be solvent could afford to offer lower rates during the crisis (see the illustration in Panel A of Chart 3). Our proxies for liquidity include a low exposure to liquidity demand risk, a buffer of liquid assets, and a low reliance on wholesale funding. Proxies for solvency (or perceived solvency) include low nonperforming loans, robust capital adequacy, and an indicator of "too-big-to-fail" bank size. The variable crisis represents a dummy variable indicating the period of the 2007-2009 financial crisis. We describe these measures and how they are empirically represented at greater length in Section 3.3. We estimate the model and test, respectively, 


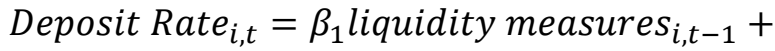

$$
\begin{aligned}
& \beta_{2} \text { liquidity measures }_{i, t-1} \times \text { crisis }_{t}+ \\
& \gamma_{1} \text { solvency measures }_{i, t-1}+ \\
& \gamma_{2} \text { solvency measures }_{i, t-1} \times \text { crisis }_{t}+ \\
& \text { bank fixed effect }_{i}+\text { time fixed effect }_{t}+\text { other controls }_{i, t}+e_{i, t}
\end{aligned}
$$

Hypothesis 2: $\beta_{2}<0, \gamma_{2}<0$.

Third, in practice, deposit rates and deposit quantities are jointly determined. Weak banks can moderate a deposit drain by offering higher rates. At the same time, exogenous inflows of deposits afford banks the opportunity to reduce their rates. ${ }^{9}$ Specifically, we estimate and test, respectively Deposit Rate $_{i, t}=\beta_{1} \Delta$ Deposit $_{i, t}+$ fundamentals $_{i, t-1}+$ bank fixed effect $_{i}+$ time fixed effect $t_{t}+$ other controls $_{i, t}+e_{i, t}$ $\Delta$ Deposit $_{i, t} \quad=\beta_{2}$ Deposit Rate $_{i, t}+$ fundamentals $_{i, t-1}+$ bank fixed effect $_{i}+$ time fixed effect $_{t}+$ other controls $_{i, t}+e_{i, t}$

Hypothesis 3: $\beta_{1}<0, \beta_{2}>0$.

In the absence of instruments, the observed relationship between deposit rates and quantities represents the set of equilibria resulting from the intersection of the two curves as shown in Chart 3 . In order to trace out the downward sloping curve where greater deposit inflows depress rates, we use deposits of nearby failed banks as an instrument for a bank's deposit growth (this identifies the bank supply curve as illustrated in Panel B of Chart 3). That is, the more that deposits in a bank's geographic market were in deposit accounts at failed banks, the more likely a nearby surviving bank is to receive some of these funds. This variable is constructed using information on failed banks together with branch data from the Summary of Deposits (see Appendix). ${ }^{10}$

In order to trace out the upward sloping demand for deposit curve, potential candidates for instruments of the deposit rate are the cost of funds from alternative sources. These sources are the wholesale market including the interbank market (as reflected by the LIBOR spread over Treasury, the TED spread) and the discount window. Note that time fixed effects are excluded in this instrumented regression because the instrument is time-varying only.

\footnotetext{
${ }^{9}$ The existing literature on depositor discipline looks at each of deposit rates and flows separately (see the discussion in Section 6.1), with the exception of Maechler and McDill (2006) whose primary interest was in estimating the positive response of deposit quantities to the deposit rate.

${ }^{10}$ Anecdotal evidence supports the use of this instrument. For example, North Carolina based BB\&T Corp. managed to attract $\$ 1.2$ billion of deposits from Wachovia, also based in North Carolina, during the third quarter of 2008 and expected more inflows at the time of the report (Bloomberg, October 20, 2008). Wachovia was acquired by Wells Fargo at the end of that quarter.
} 


\subsection{Aggregate Evidence from the 2007-09 Financial Crisis}

This section brings together evidence documenting that banks were indeed exposed to the financial crisis via credit losses and uncertainty surrounding these losses, which we assumed for the hypotheses in section 3.1. At the same time, the banking system faced an increased demand for liquidity via credit lines drawn by corporate borrowers and ABCP conduits. However, the banking system did not gain proportionate deposits to match its funding needs, especially prior to the Lehman failure.

\subsubsection{The Exposure of the Banking System to the Financial Crisis}

First, we note that risks were more concentrated in the banking system than in financial crises of the recent past. The banking system's profitability fell as the aggregate return on assets dropped from $1 \%$ at an annual rate at the start of 2007 to nearly $-1 \%$ by the end of 2008 . In contrast, return on assets had hovered around 1\% during the earlier episodes of financial stress, like the 1998 LTCM crisis (see Mora, 2010, for evidence on the banking system's performance).

Second, commercial banks were especially affected in this crisis because of their exposure to real estate loans and mortgage-related securities, whose values sharply declined. As noted by Brunnermeier (2009) and Diamond and Rajan (2009), among others, a significant portion of new financial instruments found their way on to commercial and investment bank balance sheets. As a result, commercial banks' holdings of real estate loans and mortgage-backed securities accounted for about $40 \%$ of the total amount of such loans and securities outstanding in 2007 (Mora, 2010). Not only were banks directly holding mortgage-related securities but they had also offered liquidity and credit support to issuers of debt backed by mortgage securities. For example, banks like Bank of America and Citibank, were sponsors of many off-balance sheet vehicles issuing ABCP. In July 2007, outstanding $A B C P$ equaled $\$ 1.2$ trillion, accounting for the largest part (55\%) of the $\$ 2.2$ trillion commercial paper market, up from only $20 \%$ of the market in 1997 . The first sign of a systemic liquidity freeze was the sharp tumble in outstanding ABCP by $17 \%$ from July to August 2007 (roughly $\$ 200$ billion). This drop was essentially a run by investors in $A B C P$ that refused to reinvest when the $A B C P$ matured and $A B C P$ issuance came to a halt (Covitz et al, 2009). Even ABCP conduits that suffered material credit deterioration were brought on to sponsors' balance sheets beginning in August 2007. As a result, the recourse and credit guarantees provided by sponsors ended up covering $97 \%$ of maturing $A B C P$ (Acharya, Schnabl and Suarez, 2009). 
Third, all banks, not just banks with a concentrated exposure to mortgage-related securities, suffered in the crisis due to the panic that developed from a lack of information and loss of confidence (Gorton, 2008). ${ }^{11}$

Finally, in addition to banks' direct exposure via credit losses and support to ABCP conduits, banks experienced the standard drawdown of commitments from nonfinancial borrowers shut out of the commercial paper and other securities markets (Ivashina and Scharfstein, 2010, Montoriol-Garriga and Sekeris, 2009, and Gao and Yun, 2009, provide empirical support based on firm-level data). This increase in demand for liquidity took place in two waves: In the first wave, the commercial paper spread first reached over 100 basis points in August 2007, and a second wave of market stress took hold in September 2008, following the Lehman bankruptcy and the failures of other financial institutions, as commercial paper spreads shot up above 200 basis points and outstanding unsecured commercial paper dropped $13 \%$ from a month earlier.

\subsubsection{Deposit Inflows and Funding Pressure}

To examine deposit flows, we employ data from the Federal Reserve $\mathrm{H} 8$ release of balance sheet data for weekly commercial bank reporters. The deposit data, although aggregated, are sufficiently rich to support a number of stylized facts summarized in Charts 4-6.

First and as evident in Chart 4, net deposit inflows were not especially robust in the first phase of the financial crisis: from the ABCP freeze in the summer of 2007 to just before the Lehman failure on September $15,2008 .{ }^{12}$ Thus, it would be over-simplifying to lump together the 2007-09 crisis into one period and compare deposits before and after the crisis. Second, it would also be over-simplifying to conclude that core deposits were stable throughout the crisis even if non-core deposits (such as large time deposits) were not. Third, there was considerable heterogeneity across large and small banks. We take up these points in greater detail in what follows.

Table 1 shows an extract of cumulative growth statistics for insured, core and large-time deposits, respectively, based on the quarterly Call Report balance sheet data over the period 2007:Q3-

\footnotetext{
${ }^{11}$ Indeed, Rajan (2005) was prescient about the transmission of the 2007-2009 crisis. He argued that the reason banks were able to honor their credit lines when the commercial paper market dried up in 1998 was because banks were not perceived as credit risks themselves so that funds flowed into banks. But he went on to say that if "banks also face credit losses and there is uncertainty about where those losses are located, only the very few unimpeachable banks will receive the supply of liquidity fleeing other markets. If these banks also lose confidence in their liquidity-short brethren, the inter-bank market could freeze up, and one could well have a full blown financial crisis."

${ }^{12}$ This is in contrast to deposit inflows into banks during the crisis of 1998 (see Table 7 and the evidence in section 5.1). Similar evidence of weak deposit growth in the first year from August 2007 and the contrast with 1998 is documented in Ashcraft, Bech and Frame (2010), who show that investor funds in 2007 shifted to purchasing Treasury securities or government-backed agency securities.
} 
2009:Q1 (see Appendix Table A2 for full detail). As first noted in the Introduction, core and insured deposit growth rates were, in fact, muted in the first year of the crisis. For example, insured deposits registered a cumulative growth of only 1\% (1.7\%) at small (large) banks over the four quarters, 2007:Q3 -2008:Q2. Within the subset of small banks, core deposits fell in this period, where cumulative core deposit growth equaled $-0.5 \%$. The weak behavior of core deposit growth is striking in light of the substantial easing of monetary policy during the 2007-09 crisis. From September 2007 to April 2008, the federal funds target was reduced by 3.25 percentage points, and the 3-month Treasury bill rate fell nearly three points. Such a reduction in market interest rates (the opportunity cost of deposits) usually leads to faster growth in core deposits.

In contrast, only in the aftermath of the Lehman failure and the jump in aggregate uncertainty (as proxied by the implied volatility VIX index in Chart 4), did deposit funds sharply increase. For example, deposits shot up by $\$ 188.6$ billion dollars in the week of September 17, 2008 relative to the previous week, while the VIX reached 36 from 24 the previous week. This deposit surge after the Lehman failure was visible across both types of deposits and at both large and small banks, though it was marked at the large banks (Charts 5-6). These deposit inflows reflected the acute flight to safety out of money market funds immediately after the Lehman failure. While banks remained heavily exposed to losses on real estate loans and mortgage-related securities, other institutions, especially money market funds, were suddenly perceived to be even riskier. For example, the Reserve Primary Fund, a prime money market mutual fund with close to $\$ 800$ million of exposure to Lehman commercial paper, managed to "break the buck" on September 16, 2008 when its net asset value fell below $\$ 1$. This event led to redemption demands across the money market mutual fund industry-in an amount close to $\$ 200$ billion - as well as to a reallocation of funds to safer Treasury-only funds (Adrian et al, 2010; Kacperczyck and Schnabl, 2010; Federal Reserve Bulletin, 2009). ${ }^{13}$ At the same time, households withdrew assets from the stock market and mutual fund shares, which also took a hit around the same time.

Deposit growth was then supported by the adoption of emergency measures by the government. The Emergency Economic Stabilization Act (TARP) that passed in Congress on October 3, 2008 provided greater explicit government support of the financial system, including an increase in the

\footnotetext{
${ }^{13}$ While only the Reserve Primary Fund halted redemptions on September 16, 2008, other funds were close to halting redemptions, which was averted by the U.S. Treasury announcement on September 19 of an explicit guarantee on all money market investments made prior to the Lehman failure. For example, a number of troubled funds (such as Columbia, Dreyfus, General, ING and Morgan Stanley) filed petitions with the SEC, which in turn issued no-action letters, indicating that the sponsor provided financial support to its fund (see Kacperczyk and Schnabl, 2011).
} 
deposit insurance limit from $\$ 100,000$ to $\$ 250,000$ per depositor and bank recapitalization measures. This change was followed on October 14 with the FDIC's announcement of its temporary liquidity guarantee program. The FDIC stood willing to guarantee newly issued senior unsecured debt of banks and thrifts and to fully cover noninterest bearing deposit transaction accounts, largely held by businesses. Together with other implicit guarantees of the financial system, these measures assured depositors that the banking system would hold up. As a result, deposits poured into banks.

While the focus of this paper is not on lending (see, for example, Ivashina and Scharfstein, 2010; Cornett, McNutt, Strahan and Tehranian, 2011; Gozzi and Goetz, 2010; Mora, 2010), a number of stylized facts stand out in support of deposit funding pressure relative to lending needs. First, bank loans increased in the first year of the crisis reflecting loan commitment takedowns and mortgage loans that were warehoused because they could no longer be securitized (large banks also appreciably increased their holdings of MBS and ABS securities and trading assets as shown in Table A2 and He, Khang and Krishnamurthy, 2010). Second, this lending growth outpaced core deposit funding growth (Chart 6 and Table A2). Banks, especially small banks, drew down liquid asset buffers to support lending and the buildup of assets (Chart 6 and Table A2). Loan growth would have had to slow even more if banks had not also turned to other sources of funds to make up for the shortfall in deposit growth, which included borrowing from the Federal Home Loan Bank (FHLB) System and the Federal Reserve System. ${ }^{14}$ In summary, the increased demands on bank liquidity starting August 2007 and the lack of proportionate gain in deposits contributed to funding pressure on banks and created a motive for them to offer higher deposit interest rates.

\subsection{Bank-Level Evidence from the 2007-09 Financial Crisis}

We now turn to empirical tests of the hypotheses sketched out in Section 3.1 concerning the factors that are expected to influence a bank's decision to actively manage its deposit rates. As discussed in Section 3.2, deposit funding pressure appears to have been more intense in the first part of the crisis. Therefore, the variable crisis in the testable hypotheses is empirically represented by two

\footnotetext{
${ }^{14}$ Federal Home Loan Banks are government-sponsored entities able to issue debt at cheaper rates than banks (at least in the first year of the crisis) and re-intermediate these funds by lending them to commercial banks and thrifts (Ashcraft et al, 2010). Indicative of the extent to which the U.S.-chartered commercial banking system was reliant on federal sources of funds, Federal Reserve loans rose $\$ 559$ billion from 2007:Q4 to 2008:Q4, compared with a total net increase in bank liabilities of $\$ 1,421$ billion. The FHLB stepped in earlier, with their loans increasing \$261 billion from 2007:Q3 to 2008:Q3 (Federal Reserve's Flow of Funds Table F.110 for U.S. chartered commercial banks). Bord and Santos (2011) show that liquidity-short banks (as proxied by reliance on FHLBs and the Fed discount window) imposed a cost on their borrowers in the form of higher fees on new lines of credit.
} 
dummy variables, crisis1 and crisis2. Crisis1 refers to the period from 2007:Q3 to 2008:Q2, while crisis2 refers to the period from 2008:Q3 to 2009:Q2. That is, the regressions allow bank behavior to differ in the early and late stages of the recent crisis, as represented by the interaction terms between bank fundamentals or industry effects and crisis1 or crisis2.

Several sets of regressions are estimated using observations on the deposit rates of individual banks from 1990 through 2009. These regressions are followed by a look at quantities, as reflected by deposit growth and its endogenous determination with deposit rates. Next, the interdependence of bank rates is examined. We end by revisiting the results in Gatev and Strahan (2006) on banks' advantage in the provision of liquidity insurance when market conditions are stressed.

\subsubsection{Data and variable description}

The Appendix provides a detailed description of regression variables, and summary statistics follow in Table A1. Most bank-level variables are from the quarterly Reports of Condition and Income that banks file with regulators (Call Reports). Banks belonging to a common holding company are aggregated to the top holder and treated as a single banking organization (following Kashyap, Rajan and Stein, 2002; Gatev and Strahan, 2006). Therefore, any reference to a "bank" in the remainder of this discussion should be taken to mean a banking organization. The panel is unbalanced and merger effects are controlled for by excluding observations when the quarterly growth rate of a bank's total assets exceeds a certain threshold-in this case, 10\% (e.g., Gatev and Strahan, 2006). The sample excludes the smallest banks with assets less than $\$ 100$ million. Growth rates as well as implicit deposit rates calculated from the Call Reports are winsorized at the $1^{\text {st }}$ and $99^{\text {th }}$ percentiles to mitigate the effect of outliers. The regressions include fixed effects for both banks and time (quarterly time dummies), although robustness checks are also carried out on a pooled sample without bank fixed effects. Standard errors are clustered at the bank level.

The primary deposit rates used in the analysis are the rates on large-time deposits and the rates on core deposits. These are implicit rates based on quarterly Call Report data, defined as interest expenses on deposits divided by the quarterly average of the respective interest-bearing deposits.

As briefly outlined in Section 3.1, deposit rates are expected to be sensitive to a bank's liquidity and solvency risk especially when funding conditions are stressed. The liquidity measures employed in the analysis are proxies for liquidity demand risk, liquid assets, and wholesale funding. The solvency measures are nonperforming loans, capital, and a large bank indicator for institutions perceived to be less vulnerable to insolvency risk. We describe these measures at greater length below. 
First, exposure to liquidity demand is measured by a bank's unused commitments ratio, which is defined as the ratio of unused loan commitments to the sum of loans and unused commitments. Unused loan commitments are the parts of credit lines that have not been drawn down, and include, for example, support to ABCP program conduits that the bank does not consolidate on its balance sheet (as described in the notes to schedule RC-L on the Call Reports). The rationale for measuring a bank's liquidity demand exposure by the unused commitment ratio is that the more commitments a bank has outstanding, the more exposed it will be to a drawdown of commitments when market conditions tighten. But the key finding of previous studies is that more exposed banks are not, in fact, more fragile but instead serve as liquidity backstops. While these banks converted a lot of the off-balance sheet commitments to on-balance sheet loans, they experienced a more than offsetting inflow of funds into deposit accounts in times of market stress.

Second, banks holding a larger buffer of liquid assets or with a low dependence on wholesale funding are expected to be less vulnerable to runs and potential failure. Liquid assets are assets such as cash, federal funds sold and securities that can be easily converted to cash to pay off drawn deposits and credit lines. Because of the sudden illiquidity of mortgage-backed securities and other structured securities in the 2007-09 financial crisis, and following Cornett et al (2011), the liquid asset measure excludes MBS and ABS. Wholesale funds (also known as managed liabilities in the Federal Reserve Bulletins) are liabilities excluding core deposits.

Third, solvency and capital adequacy measures are captured by the bank's capital-to-asset ratio (which can be measured in various ways, including a leverage-type measure or a Basel risk-based ratio) and the bank's nonperforming loan ratio. Well-capitalized banks and banks with a low share of nonperforming loans are less likely to fail because capital can serve as a buffer when unexpected losses occur. While these different measures of solvency are correlated, it is not evident, a priori, which measure empirically constrains banks the most. For example, banks may pay close attention to their regulatory risk-based capital ratios and disregard overall leverage to an extent, since regulatory interventions are often contingent on the regulatory risk-based ratios. Investors may, however, recognize that risk-based ratios are to a large extent "managed" by banks, and thus pay close attention also to overall leverage ratio. In addition, for the subset of publicly traded banks, we collect measures of the market value of capital to asset ratio, and equity returns and volatility as a robustness check.

Finally, perceived solvency risk is driven by implicit guarantees of certain banks. For example, large banks may be big enough to be considered by investors as "too-big-to-fail" (TBTF). Large banks 
are captured in the regressions by an indicator for the 25 largest banks as measured by asset size. ${ }^{15}$ One caveat on deposit rates is that U.S. bank regulations exist to restrict the rates that less than wellcapitalized banks can offer (Federal Deposit Insurance Act section 29, and FDIC rules and regulations section 325.103 for capital category definitions). These deposit rate caps are, therefore, expected to dampen the sensitivity of a bank's deposit rates to its riskiness. This effect, once a bank is under prompt corrective action, should however go against finding statistically and economically significant effects. ${ }^{16}$ It is, nonetheless, possible that a bank anticipating that it will soon be classified as less than wellcapitalized may have an incentive to be "active" earlier by raising its rates to attract deposits.

\subsubsection{Deposit Rates and Bank Fundamentals}

This section focuses on the results of the first two hypotheses laid out in Section 3.1. Table 2 shows the results for subsequent bank failure and Table 3 expands the set of factors that proxy for a bank's vulnerability to liquidity and solvency risks. Deposit rate behavior surrounding the time of failure is in Panel A of Table 2 and deposit flows are in Panel B. The first three columns of Panel A are for the rates on large time deposits and the last three columns are for the rates on core deposits. Each dependent variable is associated with three models that differ in how the explanatory variable, failure, is defined: First, failure is limited to regulatory-assisted failures ("formal fail"). Second, failure is inclusive of "formal fails" and "near-fails" (the latter are as defined in the Introduction and for Chart 1 - the first period in which a bank's equity return was worse than $-90 \%$ over the previous 18 months using daily CRSP data). Finally, the third model is limited to near-fails in order to determine the behavior of rates and flows after "failure". Because "formal fails" drop out of the sample after failure, this model is evaluated on near-fails only. In total, there are 517 unique bank "formal" failures represented in the Call Report sample covering the period 1991-2009, and 91 near-fails, of which 16 overlap as both nearfails and subsequent formal fails (note that bank failures, in particular the near-fails, are concentrated in the 2007-2009 crisis).

\footnotetext{
${ }^{15}$ This cutoff follows the $\mathrm{H} 8$ criteria. Results are very similar if the cutoff is based on total deposits instead of total assets. Results are also similar for other cutoffs, such as the largest 10 banks.

${ }^{16}$ We find that the results of the next section are not sensitive to excluding banks meeting the prompt corrective action criteria. It is worth pointing out, however, that the rule applies to a small group of financial institutions: For example, only 248 out of more than 8200 banks were less than well-capitalized as of 2009:Q1 (see http://www.fdic.gov/news/news/press/2009/pr09082.html). In particular, none of IndyMac, WaMu or Wachovia were less than well-capitalized with the possible exception of IndyMac based on its final quarterly statement. Also, the rule governing deposit rate restrictions was ambiguous allowing banks leeway in their interpretation of the local market. As a result, the FDIC amended section 29 of the act in May 2009, effective January 2010.
} 
The results in the top panel of Table 2 are supportive of the first hypothesis: Premiums on deposit rates were positive in the period leading up to a bank's failure. And these premiums typically increased as the bank was about to fail. For example, as shown in column (2), the premium on largetime deposits steadily rose from an insignificant 0.5 basis points (bp) four quarters before failure to 5.1 bp one quarter before failure (where failure is inclusive of formal and near-fails). Note that these coefficients can be interpreted as premiums above average rates as the panel regressions include quarterly time dummies, in addition to controlling for District-time trends, geographic deposit market concentration, and bank fixed effects. What is interesting is that higher deposit rates were not limited to large time deposits, but also characterized core deposit rates. For example, the premium reached 8.7 bp on core deposits in the period of failure (column (5)). Moreover, higher rates persisted after the quarter of near-failure. For example, banks like Citibank that experienced large drops in market value at the end of 2008 continued to pay out higher rates in the ensuing quarters (column (6)). ${ }^{17}$

In Panel B of Table 2, overall deposit quantities are in the first three columns and insured deposits are in the last three columns. Depositors withdrew total deposits leading up to a bank's failure. For example, as shown in column (2), quarterly deposit growth decreased from about -0.5 percentage point to -3.4 percentage points in the last quarter for inclusive fails (and more so for formal fails as shown in column (1)). A key difference is in the behavior of insured deposits: Despite an overall deposit drain prior to failure, these banks were able to attract insured deposit inflows. This attests to the role of deposit guarantees in weakening depositor discipline. However, this inflow was overturned in the last quarter before failure (columns (4) and (5)), and interestingly, persistent outflows from insured deposit accounts were seen after failure in the case of near-fails (column (6)). Overall, therefore, the results presented in Table 2 are in line with the hypothesis that banks about to fail experienced increasingly large deposit outflows and reacted by raising deposit rates in an effort to stem the loss.

The second hypothesis outlined in Section 3.1 is that deposit funding pressure during the crisis should show up also across different banks. While most banks did not fail, there was considerable variation in a bank's vulnerability to the risk of illiquidity or of insolvency. To test this hypothesis, the specifications in Table 3 include two sets of bank characteristics, liquidity measures and solvency measures, as described at the beginning of this section. The sample is quarterly from 1996 through

\footnotetext{
${ }^{17}$ Note that these results characterize average (implicit) rates on a bank's large-time or core deposit accounts, and therefore represent a lower bound on deposit promotions. The premiums are larger if one focuses on current offered rates. This information is not reported on the Call Reports, but is available from a participatory-based weekly survey on a selection of banks (Chart 1 ). In the latter case, premiums rose significantly in the week of failure to, for example, 30 bp on new 12-month CD rates (after also controlling for weekly time dummies, bank fixed effects, and the other market controls).
} 
2009 (this sample period also applies for the regressions in the subsequent tables, unless otherwise noted). Unused commitments are available from 1990 but the Basel risk-based capital ratio is only defined from 1996. In addition, the deposit market concentration control is from the FDIC's Summary of Deposits, available from 1994. Likewise, liquid assets are defined to exclude MBS and ABS securities, and the latter are only reported from 1994. The first two columns of Table 3 report the results for large time deposits followed by core deposits in columns (3) and (4).

The results indicate that banks that raised deposit rates were those vulnerable to liquidity risk, especially in the first year of the crisis. The key coefficient of interest, for example, is the interaction term of unused commitments with the dummy variable indicating the first year of the crisis, unused commitment ratio $x$ crisis1. For example, banks with a greater amount of unused commitments outstanding offered significantly higher deposit rates in that period: columns (1) and (2) show that a 0.1 increase in the unused commitment ratio raises the large time deposit rate by 1.4-1.8 bp. Banks exposed to liquidity demand even raised rates on core deposits in this phase of the crisis in a specification without bank fixed effects in column (4). In the second year of the crisis, funding pressures eased and these banks offered significantly lower rates. Similarly, banks relying on wholesale funding, also sought to attract deposits by raising rates, particularly in the first year of the crisis (e.g., column (3) shows that a 0.1 increase in the wholesale funding ratio is associated with a $1.3 \mathrm{bp}$ increase in the core deposit rate). Finally, banks holding more liquid assets were able to offer lower rates on core deposits.

Bank measures closely related to solvency also helped to lower rates. Banks with higher nonperforming loans typically pay significantly higher deposit rates and this sensitivity went up further during the crisis, especially in the latter part of the crisis as nonperforming loans accumulated, as reflected by the coefficient on the double interaction term, NPL x crisis2.

Measures of a bank's capital adequacy enter as expected in normal times. Specifically, the regressions include two measures of capital adequacy, the book capital-to-asset ratio and a Basel total risk-based capital ratio. However and especially in the first year of the crisis, well capitalized banks by the capital to asset ratio raised rates (or offered a lower discount from before). ${ }^{18}$ For example, a 0.1 increase in the capital-to-asset ratio led to an increase in the large time deposit rate by $4.6 \mathrm{bp}$ (column (1)). In contrast, well capitalized banks by the Basel risk-based measure lowered rates during this period. The direction of these effects is not sensitive to including these measures jointly or separately in the regressions.

\footnotetext{
${ }^{18}$ Results are also similar if the total book capital to asset ratio is replaced with higher quality capital such as tangible capital or tangible common capital ratios.
} 
One interpretation is that banks are sensitive to regulatory intervention and adjust their deposit rates upwards when regulatory risk-based capital positions deteriorate. At the same time, the evidence that banks with higher book capital to asset ratios offered higher rates in the first year of the crisis may reflect the greater ability and better position these healthier banks were in to increase lending in the crisis (for example, in results later discussed, there is evidence that banks with a high capital ratio increased lending more in the crisis, but only banks with higher risk-based capital ratios were able to attract more deposits overall). ${ }^{19}$

Finally, banks enjoying implicit support such as the TBTF institutions generally pay lower rates, and were also associated with lower deposit rates during the crisis, particularly during the first year. For example, large banks lowered rates by 5-17 basis points in the first year of the crisis and the effect is statistically significant for core deposits (columns (3) and (4)). ${ }^{20}$ Alternatively, bank size can be measured by the log of total assets; albeit this is a less direct measure of implicit guarantees than the TBTF indicator. In similar specifications and including log assets, the interaction terms on size and the crisis are likewise negative and statistically significant.

The upshot of the results in Table 3 is that banks actively respond to their deteriorating positions - whether liquidity demand risk or solvency risk - by offering higher deposit rates. The effect of bank riskiness on deposit rates was particularly amplified during the crisis because of the direct negative impact the crisis had on the banking system as outlined in Section 3.2.

\subsubsection{Deposit Inflows and the Joint Determination of Deposit Rates and Flows}

We next turn to evaluating the responsiveness of deposit flows to a bank's risks of illiquidity and insolvency. Results of deposit growth regressions are shown in Table 4 for several deposit types, including total deposits and a measure of "stable" deposits (core deposits). The motivating question is whether deposit inflows respond to bank riskiness and whether the association changed in the crisis. The data on aggregate deposits suggested that the banking system as a whole was not particularly able to attract deposits in the first phase of the crisis. Such a shortfall in overall deposit inflows would be of special concern if deposit inflows at banks with high exposure to liquidity demand did not increase as

\footnotetext{
${ }^{19}$ Alternatively, one can also examine the market value of equity to asset ratio (and market equity returns) for the subset of banks with publicly traded equity data from CRSP (see Appendix Table A7). As expected, banks with higher market equity returns (and lower volatility of daily returns) decreased deposit rates in the crisis. However, banks with higher market capital ratios raised large time deposit rates in the first phase (but the effect is not statistically significant), possibly because these banks were increasing lending during the crisis.

${ }^{20}$ We continue to find a TBTF effect even if we eliminate banks with assets less than $\$ 1$ billion. Banks above $\$ 1$ billion in assets have roughly similar core and insured deposit profiles as the largest banks.
} 
much relative to other banks as in past events of turmoil (despite their offering higher rates as shown in the previous section).

The regression results confirm that such a shift in relative deposit growth occurred in the first phase of the recent crisis. For example, the interaction term of unused commitments with the first year of the crisis, unused commitment ratio $x$ crisis1, enters negatively for both total and core deposit growth in columns (1) and (2) (implying that a 0.1 increase in the exposure to unused commitments is associated with close to a 0.1 percentage point decline in deposit growth). Although not statistically significant, it was nonetheless the case that banks with unused commitments did not have a systematic advantage at gaining deposits, unlike previous episodes of stress (as explored further in Section 5.1). Consistent with these findings, banks seeking brokered deposits and choosing to participate in the FDIC's transaction account guarantee program at the end of 2008 were those that had a high unused commitment ratio (columns (3) and (4)). This program was part of the FDIC's temporary liquidity guarantee program announced on October 14, 2008. The FDIC stood willing to guarantee newly issued senior unsecured debt of banks and thrifts and to fully cover noninterest bearing deposit transaction accounts, largely held by businesses. Those banks choosing to participate paid an extra premium for the additional insurance (the results are robust to controlling for the share of transaction deposits).

Other results are mostly in line with priors, despite the fact that a regression of deposit quantities on fundamentals may produce ambiguous effects: Weak fundamentals cause depositors to take their deposits elsewhere but banks respond by actively raising rates (see Chart 3 and the discussion in the introduction and Section 3.1). This endogeneity issue is next addressed in Table 5. Nonetheless and accepting that the estimated coefficients in Table 4 may be obscuring quantity effects, more liquid banks gained deposits as did better capitalized and large banks. For example, large banks experienced 1 percentage point greater deposit growth (column (1)). This differential effect is considerable, considering that average quarterly deposit growth over the sample was 1.1 percent (Appendix Table A1). Collectively, these findings imply that banks were not indiscriminately seen as safe havens during this crisis.

Next, we examine the endogeneity of deposit rates and flows in a test of the third hypothesis from Section 3.1. In particular, we address the concern that rates on deposits are pushed down by deposit inflows at the same time that deposits are gained by offering higher rates in Table 5. Panel A traces out the downward sloping curve with the deposit rate as a function of deposit growth, the "bank supply" curve. As discussed in Section 3.1, in order to tease out this effect, deposits of nearby failed banks are used as an instrument for deposit growth. The results of the first stage indicate that, as 
expected, the failed deposit share positively influences deposit growth, particularly insured deposits, which are arguably more sensitive to deposit inflows from failed banks seeking a safe haven. The latter significant effect implies that a 0.1 increase in the failed deposit market share leads to a 1 percentage point increase in insured deposit growth (column (2)). The second stage regression is shown in column (3). In line with the hypothesis, rates go down as insured deposits pour into banks: so that a 1 percentage point increase in deposit growth pushes rates down by 1.25 basis points. This negative relationship was weaker during the crisis (as captured by the double interaction terms, deposit growth $x$ crisis1 and deposit growth $x$ crisis 2 shown in column (4)). Finally, the coefficients on the other terms capturing bank's liquidity and solvency are robust and similar to Table 3.

In order to trace out the upward sloping demand for deposit growth as a function of the deposit rate (the "depositor demand" curve), we use the TED spread to instrument for the deposit rate in Panel B of Table 5. The results of the first stage are consistent with the prior: For example, a 100 basis point increase in the TED spread pushes the deposit rate up by 35 basis points (column (2)). The second stage results in column (3) show that the deposit rate has a positive and statistically significant effect on rates. The coefficient estimate is equal to 0.004 , significant at the $1 \%$ level, implying that a one standard deviation in the deposit rate leads to a 0.16 percentage point increase in quarterly deposit growth. Interestingly, the sensitivity of deposit growth appears to have been greater to the deposit rate in the crisis with positive and significant coefficients on the interaction terms, large-time rate $x$ crisis 1 and large-time rate $x$ crisis2, as shown in column (4).

Finally, it is worth noting that accounting for the reaction of the deposit rate, uncovers a stronger relationship between deposit quantities and fundamentals that was partly masked in the results in Table 4. For example, the second stage results imply a greater effect on deposit outflows from unused commitments in the first year of the crisis, which is now significant at the $10 \%$ level (column (3)). Similarly, the coefficient on the interaction term of wholesale funding with crisis 1 is -0.003 to -0.009 in columns ( 3 ) and (4) compared with -0.002 in column (1) of Table 4 (that is, up to a 0.09 percentage point contraction in deposit growth for a 0.1 increase in the wholesale funding ratio). Likewise, deposit inflows into large banks are estimated to have been even greater in the first year of the crisis; 1.1 to 1.4 percentage points compared with 1 percentage point in Table 4, which was contaminated by the effect that large banks also lowered rates. To summarize, we have shown that deposit rates and quantities are jointly determined, and banks can mitigate a deposit drain by raising their rates. ${ }^{21}$

\footnotetext{
${ }^{21}$ We have also conducted additional tests documenting bank lending and liquidity management in the crisis. The results are very similar to those obtained in recent studies including Ivashina and Scharfstein (2010), Cornett et al
} 


\section{THE INTERDEPENDENCE OF RATES: INDUSTRY AND GEOGRAPHIC MARKET EFFECTS}

Having devoted considerable attention to the relationship between a bank's deposit rates and its own fundamentals, in this section we consider how rates are shaped by the behavior of other banks in the system as well as by the geographic deposit market structure where the bank is located.

\subsection{Hypothesis Development: An Industry Equilibrium View}

Not only is the deposit rate offered by a bank expected to depend on its own fundamentals, but it is also expected to depend on the deposit rate policies of other banks in the system. That is, when other banks offer higher rates, that action can push up the rate for bank $i$, controlling for its fundamentals and other market conditions. ${ }^{22}$ Specifically, if $r_{i t}$ is the deposit rate of bank $i$ and $\bar{r}_{-i, t}$ is the average deposit rate of other banks, then we estimate and test, respectively $r_{i t}=\beta_{1} \bar{r}_{-i, t}+\beta_{2} \bar{r}_{-i, t} \times$ crisis + fundamentals $_{i, t-1}+$ other controls $s_{i, t}+e_{i t}$ Hypothesis 4: $\beta_{1}>0$, and $\beta_{2}>0$ if industry effects were heightened in the crisis.

Digging deeper at this key hypothesis, one reason that other banks may raise their rates is because they are likely to fail (as shown in Table 2). Therefore, it is natural to expect that if a bank is located in a geographic market with a high share of deposits in banks that are about to fail, then even a healthy bank will face pressure to increase rates in the time period preceding failure. That is, a bank in Pasadena, California would have felt pressure to raise its deposit rates in early 2008 because Pasadenabased IndyMac was bidding up rates at the time. As IndyMac got closer to bankruptcy in July 2008, and in the immediate aftermath, the pressure on other banks to maintain deposit rate promotions would have eased. Therefore, an alternative representation of hypothesis 4 is the following:

$r_{i t}=$

$\beta_{0}$ failshare $_{t}+\beta_{1}$ failshare $_{t+1}+\ldots \beta_{4}$ failshare $_{t+4}+$ fundamental $_{i, t}+$ other $_{\text {controls }}, t+e_{i t}$

(2011) and Gozzi and Goetz (2010), and are therefore not shown in the interest of space. For example, banks reliant on more stable deposit funding, such as insured deposits, (or those with greater deposit inflows) were able to expand lending growth in the crisis. Well capitalized and liquid banks were also better able to support lending. In addition, banks with existing unused commitments increased loan growth in the first year of the crisis. This result may reflect involuntary lending as commitments were converted to loans. At the same time, these banks with greater existing exposure to unused commitments had more leeway in reducing overall credit (the sum of unused commitments and loans), as they cut back on the extension of new loan commitments. There is also some evidence that riskier banks shifted toward less risky borrowers (as evidenced by decreases in average loan rates suggestive of a flight-to-quality selection effect).

${ }^{22}$ Anecdotal evidence from the crisis hints at such industry effects. For example, a number of regional banks with strong balance-sheets initiated competitive deposit rate campaigns in order to "attract customers from other institutions who may not be as sure about their bank" (spokeswoman for TD Banknorth Inc., a unit of TorontoDominion Bank as cited in American Banker, October 9, 2008). 
Alternative Hypothesis 4: $\beta_{0}<0, \beta_{1} \ldots \beta_{4}>0$.

Moreover, competitive pressure from the industry is expected to be greater in competitive deposit markets. Specifically, if $H H I$ is the Herfindahl index for a bank's geographic market (from the Summary of Deposits and is branch deposit-weighted), then we estimate and test, respectively $r_{i t}=\beta_{1} H_{H I}+\beta_{2} H H I_{i t} \times$ crisis + fundamentals $_{i, t-1}+$ other controls $_{i, t}+e_{i t}$ Hypothesis 5a: $\beta_{1}<0$, and $\beta_{2}<0$ if competitive effects were heightened in the crisis.

It is also possible to extend this hypothesis one step further: Banks in more competitive markets are expected to raise rates when the rates of other banks go up:

$$
\begin{aligned}
& r_{i t}= \beta_{1} H_{H I}+\beta_{2} H_{i t} \times \text { crisis }+\beta_{3} \bar{r}_{-i, t}+\beta_{4} \bar{r}_{-i, t} \times \text { crisis }+ \\
& \beta_{5} H H I_{i t} \times \bar{r}_{-i, t}+\beta_{6} H H I_{i t} \times \bar{r}_{-i, t} \times \text { crisis }+ \text { fundamentals }_{i, t-1}+\text { other controls } \\
& i, t
\end{aligned}
$$

Hypothesis 5b: $\beta_{5}<0$, and $\beta_{6}<0$ if competitive effects were heightened in the crisis.

Finally, just as less competitive deposit markets are expected to dampen industry effects, so too are markets with an ample supply of deposit funds. One exogenous driver of deposit supply takes the form of a large fraction of seniors (65 and over) making up the local market's population. This hypothesis builds on Becker (2007) who showed that seniors hold a large share of their wealth in the form of bank deposits and this driver of deposit supply is independent of local demand conditions (we also control for variables capturing local economic conditions in the regressions). He also showed that deposits instrumented with seniors in the metropolitan area had real effects on the investment of bankdependent borrowers. The fraction of seniors is taken from the 2000 Census data and is matched to geographic areas for a bank's branches in the Summary of Deposits. Empirically, this hypothesis can be represented by a model similar to that for hypothesis 5 :

Hypothesis 6: Coefficients signed as in Hypothesis 5 when substituting the fraction of seniors for $\mathrm{HHI}$ (and controlling for HHI).

\subsection{Evidence of Interest Rate Contagion}

The results of the two specifications for hypothesis 4 are shown in the first two columns of Table 6. Panel A corresponds to the rates on large-time deposits and Panel B corresponds to the rates on core deposits. Note that while the IV regression in Table 5 employs the contemporaneous failed deposit share as an instrument for a bank's deposit inflows in the period that other nearby banks failed, the specifications shown in Table 6 also capture the behavior of rates leading up to events of failure in the local market. Also note that the regressions in Table 6 control for all the bank liquidity and solvency 
measures, whose presentation is now suppressed in the interest of space. Finally, the effect of the deposit concentration measure is shown in these tables (this measure was included throughout the previous regressions, but was not shown as those tables had a different focus). We also control for local economic conditions in the bank's geographic market as shown (change in house prices, employment and the number of establishments). ${ }^{23}$

The evidence supports the hypothesis of inter-dependence in bank deposit rates. For example, column (1) of Table 6 shows that the coefficients on the 3-4 period lead terms ahead of local market failure are positive and statistically significant (e.g., for a 0.1 increase in the failed share of the local deposit market, banks increased large time (core) deposit rates by 3.4 (1) basis points one year prior to failure). At the same time, in the quarter that a nearby bank(s) fails (and in the immediately preceding quarter), premiums on large time deposit significantly fall. Similarly, column (2) shows the direct effect that other bank rates have on a given bank's rates. Interestingly, this sensitivity was significantly heightened during the first year of the crisis, as reflected by the term $\bar{r}_{-i, t} x$ crisis 1 . For example, banks increased their large time deposit rate by 5.6 basis points for a 100 basis point increase in the rate of other banks (column (2) of Panel A).

The next two columns test whether banks in more competitive deposit markets offer higher rates. The proxy for a market's concentration is the $\mathrm{HHI}$ index (similar results are obtained if the top market share is alternatively used). The results show that the rates on large-time deposits are generally significantly affected by the bank's local market structure (e.g., the negative coefficient on the HHI term in column (3) of Panel A implies that a 0.1 decrease in market concentration is associated with $0.71 \mathrm{bp}$ higher rates, and the interaction term with the first year of the crisis was further negative, although not statistically significant). In the case of core deposit rates in Panel B, the market structure does not have a significant effect on rates in normal times. However, there is evidence that even core deposit rates were pushed up in more competitive funding markets during this crisis (the coefficients on the double interaction terms, $\mathrm{HHI}_{i, t}$ x crisis1 and $\mathrm{HHI}_{i, t}$ x crisis2, in column (3) of Panel B are negative and statistically significant). Finally and extending the argument one step further, there is evidence that banks in

\footnotetext{
${ }^{23}$ Note that the results are also robust to controlling for the interaction terms of these variables with the crisis periods. These variables are included as controls only because there are competing effects on how local economic conditions should affect deposit rates. On the one hand, a decline in house prices proxies for an adverse effect on household wealth, inducing deposit outflows and pushing up deposit rates. But house prices are correlated with demand, such as employment and other local demand conditions. In this case, a decline in house prices reflects a decline in good opportunities for investment in the local area and therefore for bank lending and the need for funds. This effect would serve to push down deposit rates.
} 
competitive deposit markets offer higher rates when other banks raise rates (the coefficient of interest for this hypothesis is the triple interaction term, $H H I_{i, t} x \bar{r}_{-i, t} x$ crisis 1 in column (4)).

The final hypothesis predicts that markets with an exogenously driven abundant supply of deposits should have similar effects on deposit rates as a less competitive deposit market structure would. We take advantage of the fraction of the population that is made up of seniors, and continue to control for the $\mathrm{HHI}$ index and local economic conditions in these regressions (the results are robust to also controlling for the interaction terms of $\mathrm{HHI}$ and local economic conditions with the crisis in, for example, column (5)). The results are supportive of the hypothesis: More seniors in the bank's geographic market helped to insulate its deposit rates and especially in the first year of the crisis (e.g., a 0.1 increase in the senior share reduced the large time deposit rate by $3.1 \mathrm{bp}$ as shown by the coefficient on Senior ${ }_{i, t} x$ crisis1 in column (5) of Panel A). The results also imply that a dominant senior population mitigated the industry pressure coming from other banks promoting higher rates (Senior $_{i, t} x \bar{r}_{-i, t} x$ crisis 1 in column (6)).

One last model is presented in Appendix Table A3, which exploits branch-level data, albeit for a smaller and participation-based selection of banks (see section 5.2.1 for a description of the Bank Rate Monitor data). Up to now, the HHI index, the share of seniors, the failed deposit share, and local economic conditions have been aggregated to the bank topholder level using branch deposit-weighted information from the Summary of Deposits. For this analysis, the geographic market information collected by the Bank Rate Monitor survey (city, state) was hand matched to the relevant geographic market (MSA or rural-county) in the Summary of Deposits data. The regressions presented control for the bank's characteristics and fixed effects at the topholder level but branch-level geographic deposit market variation is introduced. The results indicate that the direct effects of geographic characteristics enter as expected, although many of the interactions with the stress period are generally not statistically significant. For example, a branch located in a more competitive market reports higher rates but this effect is not amplified in the crisis (column (3)). However, there is evidence to support the view that these branches in more competitive markets responded in the crisis to a rate increase by other banks $\left(H H I_{i, t} \times \bar{r}_{-i, t} x\right.$ stress in column (4)).

Broadly speaking, these effects are consistent with theoretical models formalizing an interestrate contagion that spreads from financially constrained banks to those that compete in funding markets with these banks. In Acharya (2009), poor performance of some banks reduces aggregate wealth that in general equilibrium raises borrowing costs for other banks. Diamond and Rajan (2005) show that there can be an aggregate liquidity shortage in which banks seeking liquidity, e.g., by 
liquidating assets, deplete liquidity for other banks raising their cost of borrowing. Acharya and Skeie (2011) consider the possibility that funding-constrained banks hoard liquidity and raise the cost of transferring liquidity to even healthy banks in the inter-bank markets. Our result that banks compete in deposit markets and liquidity-seeking banks raise the cost of deposits for other banks is similar in spirit to these alternative contagion channels, which could also be interesting to study but are beyond the immediate scope of our paper.

Similar findings characterize other industries where distressed firms follow aggressive pricing strategies, leading to deviations from cooperative behavior and price cuts by other firms. For example, Borenstein and Rose (1995) find that airlines reduce prices in the 90-180 days before bankruptcy, and that their competitors also cut prices in this period (although the latter raise prices in the subsequent months, similar to the competing effects we find that local bank failures have on a healthy bank's rates). Busse (2002) also shows that airlines in worse financial condition are more likely to start price wars, while financially healthy airlines in overlapping routes are more likely to follow by reducing fares.

One final question that we take up in this section is whether banks competing in similar deposit pools to weak banks were more likely to fail in the crisis. The results in Table A4 indicate that interest rate contagion in the local deposit market contributed to a greater risk of bank failure, controlling for bank characteristics, pre-crisis deposit rate, local economic conditions, and deposit market structure. A more detailed analysis falls outside the immediate scope of this paper, but the results also show that both liquidity and solvency measures (measured pre-crisis because banks later took defensive actions) affected the likelihood of failure in the expected direction. For example, banks with more unused commitments outstanding before the crisis were more likely to fail (and liquidity measures are more important predictors of failure when failure covers stock return near-fails in addition to regulatory fails as shown in columns (2) and (3)).

\section{REVISITING GATEV AND STRAHAN (2006) AND OTHER ROBUSTNESS}

The results of our paper indicate that the role of the banking system as a stabilizing liquidity insurer is an active one. Banks most vulnerable to greater liquidity demand may not be able to attract sufficient deposit inflows to fund commitments and other asset funding needs even by offering higher rates, as the findings of Section 3.3 illustrate.

\subsection{Revisiting Gatev and Strahan (2006)}

One open question is how can these results be reconciled with previous studies' support for banks' advantage in liquidity provision in crises? That is, if banks have a natural advantage in providing 
liquidity in crises as posited by this literature, then banks with the greatest exposure to liquidity demand are expected to experience the highest growth in deposits and loans in a crisis. The regression results discussed in this section confirm that such a relationship existed in previous episodes of market stress but broke down in the 2007-09 financial crisis.

Table 7 presents some descriptive statistics of average weekly deposit and loan growth comparing the 1998 LTCM crisis with the 2007-09 crisis. The liquidity squeeze that followed the Russian sovereign debt default and the failure of the LTCM hedge fund in the fall of 1998 also meant that many companies could no longer renew maturing commercial paper. For example, commercial paper spreads reached over 100 bps and outstanding commercial paper issued by nonfinancial companies fell roughly $7 \%$, by $\$ 16$ billion (Saidenberg and Strahan, 1999). These companies turned to the commercial banking system as a backstop, and weekly C\&I loan growth doubled (from a weekly average of $0.027 \%$ in the five years preceding the crisis to $0.048 \%$ in the fall of 1998). At the same time, deposits flowed into U.S. banks from foreign banks and overseas offices largely because that crisis had its origins outside the U.S. as discussed by Saidenberg and Strahan (1999) (e.g., core deposit growth shot up from a weekly average of $0.042 \%$ to $0.173 \%$ in the fall of 1998 as shown in Table 7). ${ }^{24}$ In contrast and as already described at great length in Section 3.2, deposit growth was muted in the first year of this crisis as C\&I loans went up.

In order to ensure that differences in model specification are not driving the results, the specifications in Table 8 follow very closely those reported in Gatev and Strahan (2006). The key coefficient of interest is the interaction term of unused commitments with the commercial paper spread, which proxies for financial market dislocations. The coefficients on unused commitments $x$ stress are positive and statistically significant in both the deposit growth (column (1)) and loan growth equations (column (4)) for a sample period over 1991-2000 as in Gatev and Strahan. These results confirm that before the recent crisis, banks most at risk of liquidity demand realizations experienced the greatest increase in deposit growth and loan growth when financial markets became stressed.

The model is extended by allowing for a different effect stemming from a bank's unused commitments on its deposits and loans in this crisis compared with previous episodes of high commercial paper spreads and the sample period is, therefore, extended to 2009. The change in the influence of financial stress on banks' ability to provide liquidity in the recent crisis is captured by the triple interaction unused commitments $x$ stress $x$ crisis. The results in columns (3) and (6) show that the

\footnotetext{
${ }^{24}$ This translated to an increase of about $\$ 35$ billion between end-August and October 1998, further increasing by over $\$ 100$ billion by year end. Similar evidence of a strong deposit inflow into the domestic banking system occurred after the $9 / 11$ attacks as market liquidity dried up and commercial paper spreads rose. For example, total deposits shot up by over $\$ 200$ billion in the week immediately following September 11, 2001.
} 
coefficients on unused commitments $x$ stress $x$ crisis are mostly negative and statistically significant. ${ }^{25}$ These results generally support the view that banks with high exposure to liquidity demand had less of an advantage (a disadvantage in some cases) over other banks in attracting deposits and making loans in the recent crisis than in past crises. For example, before the recent crisis, an increase in the CP spread by 100 basis points raised deposit growth 0.22 percentage point more at a bank with a high unused commitment ratio than at a bank with a low unused commitment ratio (where high unused commitments are taken at the $75^{\text {th }}$ percentile (0.17) and a low unused commitments are taken at the $25^{\text {th }}$ percentile (0.07)). In contrast, when market liquidity was highly stressed in the first phase of this crisis, deposit growth contracted 0.17 percentage point more at a bank with a high unused commitment ratio than at a bank with a low ratio.

Together, the deposit and lending results suggest that the very banks that had offered insurance to businesses and households before the crisis in the form of commitments were not as well positioned to deliver the promised liquidity. Lending growth was anemic in this crisis compared with earlier episodes of high commercial paper spreads.

Finally, the deposit rate specifications in the last two columns of Table 8 show that even in the period before the 2007-09 crisis when banks were relatively untouched by market turbulence, there is evidence that banks exposed to liquidity demand shocks offered higher rates (at least on large time deposits) in order to secure adequate deposit inflows in times of market stress. This helps reconcile the findings of Gatev and Strahan that liquid assets increased universally at all banks when commercial paper spreads rose (regardless of loan commitment exposure) but that deposit inflows were pronounced at banks with high levels of loan commitments outstanding. Our results clarify that - even before this crisis - banks exposed most to liquidity demand shocks were actively managing deposit rates to attract deposit inflows rather than being purely passive recipients of deposits due to flight to safety.

\subsection{Robustness}

\subsubsection{Alternative data source for bank deposit rates}

We also arrive at compatible results when using an alternative data source, which is based on a proprietary survey of current rates (mostly on CDs) of banks and thrifts conducted at the weekly frequency by Bank Rate Monitor (Bank Rate Monitor ${ }^{\circledR}$, N. Palm Beach, FL 33408, all rights reserved). This survey has a number of advantages and disadvantages: Its main advantage is that the reported rates are

\footnotetext{
${ }^{25}$ Columns (3) and (6) also include double interaction terms as a robustness check. The coefficients of interest are those on the triple interaction terms. (See Bertrand, Schoar and Thesmar, 2007, for a similar triple interaction model).
} 
current (not average balance) rates. However, the survey is on a selection of banks and is largely participation based. As a result, the sample covers only about 214 bank holding companies of more than 4000 in the Call Reports, and these have a larger average asset size and are concentrated in metropolitan areas (and the included banks may choose to stop reporting rates during the sample). ${ }^{26}$

The results using the Bank Rate Monitor data are shown in Appendix Table A5; where the panel is a bank-week panel over the period 1997-2009 and the liquidity and solvency measures are as before (lag values are nonetheless quarterly because bank characteristics are from the Call Reports). The results indicate that, particularly for those banks with a high insolvency risk, the covariates are statistically significant and have the hypothesized economic effect in times of market stress (these covariates are unused commitments, liquid assets, nonperforming loans, and size). For example, large banks paid up to 25 basis points lower CD rates in this crisis and a 0.01 increase in the fraction of nonperforming loans pushed up rates by close to 20 basis points (see columns (1), (2), (5) and (6)).

\subsubsection{Deposit rates during the Fall of 2008}

The Bank Rate Monitor weekly data can also be used to evaluate how deposit rates responded to bank insolvency and illiquidity risk in three narrowly defined regimes around the Lehman failure: the weeks immediately preceding the Lehman event, the weeks after Lehman but before TARP, and the weeks just after TARP (and recapitalization) was approved. The sample period in Appendix Table A6 corresponds to a five-month window surrounding the Lehman event. There is some evidence that sensitivity to insolvency risk (as proxied by nonperforming loans) increased in the post-Lehman preTARP period (columns (1) and (3)). However, this finding may reflect compositional changes during that interval because the survey is participation-based. The results are, therefore, more consistent with a strong effect of insolvency risk on rates throughout the stressed period as shown in Table A5. But what is interesting, is that illiquidity risk was most acute in the period before Lehman and eased after Lehman and then more after TARP (as proxied by unused commitment in columns (4) to (8); qualitatively similar results hold for liquid assets and wholesale funding). This finding is compatible with the large flight of deposit funds into the banking system following Lehman as previously shown.

\footnotetext{
${ }^{26}$ The data are also subject to a number of irregularities as noted by Driscoll and Judson (2009); these include duplicates for the same branch and missing observations input as zeros. The data are, therefore, cleaned as best as possible to correct for these discrepancies. A second caveat is that the rate data represent the lower end of rates offered by deposit type.
} 


\subsubsection{Alternative bank risk measures}

Next, we assess how banks responded to additional risks of illiquidity and insolvency that were revealed by the 2007-2009 financial crisis. We also evaluate whether and how the maturity structure of time deposits was affected by the crisis, and whether a change in the maturity structure can explain our findings. And finally, we address the concern that the use of liquidity and solvency measures during the crisis (even with a lag) may be confounded by regulatory changes and bank-specific actions.

The first two columns of Table A7 include two measures closed related to the proximate causes of the financial crisis. First, we include the share of real estate lending in a bank's loan portfolio. Second, in the period before the crisis, banks increasingly relied on liquid loan sale and securitization markets to offload real estate loans. As a result, banks more involved in this activity would be expected to face funding pressure once these markets froze. Therefore, we also include a measure capturing the extent of residential mortgages sold (available from 2006). These two real estate dependence variables have the hypothesized positive effect on deposit rates during the crisis (e.g., a one standard deviation in a bank's real estate lending increased its core deposit rate by $1.5 \mathrm{bp}$ in the second year of the crisis, column (2)). The last four columns of Table A7 include market equity returns and volatility for the subset of publicly traded banks (results previously discussed in section 3.3.2).

\subsubsection{Effects on maturity structure of deposits}

We also show that banks with a deposit maturity structure tilted toward short-term deposits have a greater rollover risk, and offered significantly higher rates in the first year of the crisis to ensure continued funding. For example, column (1) of Table A8 shows that a one standard deviation increase in the share of large-time deposits maturing or repricing in less than one year raised the large-time deposit rate by over $5 \mathrm{bp}$. Moreover, the results in column (3), where the dependent variable is the share of short-term time deposits, indicate that the maturity structure shortened for banks more susceptible to liquidity demand risk. For example, banks with more unused commitments appear to have increased their share of short-term deposits. Therefore, it seems unlikely that riskier banks lengthened their maturity structure during the crisis (so that the higher deposit rates they paid would reflect that maturity shift rather than being an outcome of banks actively seeking deposits for a given maturity profile).

\subsubsection{Endogeneity of bank risk measures}

Finally, to address the potential endogeneity of the liquidity and solvency variables, we include their pre-crisis values in the specifications shown in Table A9. That is, lagged values are used up to 
2007:Q2 and from then on, the values of these variables as of 2007:Q2 are used. Pre-crisis (2007:Q2) characteristics are least likely to be contaminated by regulatory and bank actions taken after the beginning of the crisis in order to change risk profiles. The results are robust to this change and are, in fact, strengthened in the case of liquidity variables. For example, a 0.1 increase in a bank's pre-crisis wholesale funding ratio led to a 0.10 to 0.16 percentage point contraction in deposit growth during the crisis (column (3)) compared with an insignificant or even positive effect on deposit growth in the baseline results in Table 4.

\section{RELATED LITERATURE}

The findings in this paper help to understand the nature and importance of deposit funding shocks for banks in the recent crisis. There is a well-developed strand of the market discipline literature that shows that various types of bank claimholders are able to identify risky banks in a timely manner and penalize them by withdrawing funds and raising the costs of additional funds. In turn, a financial firm finds that it cannot borrow additional funds or that the additional funds come at very costly terms, it will be forced to adjust its corporate structure and risk-profile.

Flannery (1998) provides a good review of the capacity of such market mechanisms to supervise and remedy excessive risk taking by financial firms. But to cite just a few most relevant empirical papers on market discipline, Hannan and Hanweck (1988) find evidence that rates on partially insured CDs reflect bank riskiness; Flannery and Sorescu (1996) and Ashcraft (2008) find evidence of discipline in subordinated debt markets; Park and Peristiani (1998), Goldberg and Hudgins (2002), and Maechler and McDill (2006) find that riskier financial institutions pay higher interest rates and attract smaller amounts of uninsured deposits. There is also evidence of risk-pricing for insured deposits during the savings and loans crisis in the 1980s when the credibility of the savings and loan deposit insurance fund was in doubt (Cook and Spellman, 1994). Interestingly, even when deposit insurance is credible, there is evidence of discipline by insured depositors. For example, using proprietary account-level data for a bank that failed in 2002, Davenport and McDill (2006) show that most of the deposits that were withdrawn were, in fact, from fully insured deposit accounts.

There is also historical evidence of depositor discipline from the U.S. before the introduction of deposit insurance and other regulatory standards. For example, Calomiris and Wilson (2004) shows that depositors were able to differentiate between banks, as deposit withdrawals in the 1920s and 1930s were related to a bank's risk of default. Saunders and Wilson (1996) also find that failing-bank deposit outflows one year prior to failure still exceeded those at a matched control sample of non-failing banks, even during the bank run contagion of the early 1930s. This finding, together with our findings on 
deposit outflows in the run-up to a bank's failure, indicate that deposit withdrawals can be one interesting predictor of bank failures and distressed acquisitions.

A group of papers also finds evidence of depositor discipline when looking at other countries in modern times. For example, Schumacher (2000) looks at the effect of the Mexican devaluation in 1994 on Argentina, which started as a currency run in Argentina. At the time, Argentina had no deposit insurance or other explicit safety nets. She finds evidence of an informational component of deposit withdrawals from ex ante "bad" banks to ex ante "good" banks. The latter group was made up of banks expected to survive the currency run such as large domestic and foreign banks. Martinez Peria and Schmukler (2001) study several Latin American countries and also find evidence in support of depositor discipline on both the interest rate dimension and the outflow dimension - including for insured deposits and this was because of uncertainty over deposit protection. In contrast, Demirguc-Kunt and Huizinga (2004) focus on whether deposit insurance weakens market discipline in a sample of 30 countries and find evidence in favor of this view (also supporting Pennacchi, 2006).

Recently, deposit funding shocks for banks are shown to be of wider relevance by Liu (2011) that analyzed the effect of financial crises over the past 20 years globally on banks operating with branches in crisis-affected and non-crisis countries. She finds that banks with deposit exposure cut back lending significantly in branches outside the crisis country (funding shock); and the magnitude of this effect is twice as large as that stemming from non-depository asset exposure only (capital shock).

Finally, several recent papers on inter-bank markets also conform to the overall spirit of our evidence. Acharya and Skeie (2011) argue theoretically that banks facing funding constraints would raise the cost of lending in inter-bank markets even to healthy banks. Acharya and Merrouche (2008) and Ashcraft, McAndrews and Skeie (2010) show empirically for the UK and the US inter-bank markets, respectively, that banks facing funding liquidity problems during 2007-08 hoarded reserves and released them to other banks only at extra premium. The net effect of this was to effectively raise the cost of borrowing for other banks in the system. And, Afonso, Kovner, and Schoar (2010) find evidence of pricing and rationing in the federal funds market that is also parallel to our evidence from the retail deposit funding market. For example, using daily transaction-level data on the federal funds segment of the wholesale funding market, they find that banks with high nonperforming loans were more likely to be rationed and pay higher spreads.

\section{CONCLUSIONS}

The motivating question of this paper was whether banks can maintain their advantage as liquidity providers when they are at the center of a financial crisis. This argument hinges on deposit inflows, 
seeking a safe haven, providing banks with a natural hedge to fund drawn credit lines and other commitments. Some observers have conjectured that deposit inflows should have been an assured stable source of funding even during the 2007-09 financial crisis.

We examined whether this conjecture was valid. The main message is that bank deposit funds cannot be assumed to be robust to all types of market liquidity stress. In the crisis of 2007-09, depositors shunned banks generally when there was greater uncertainty about the health of banks, greater aggregate uncertainty, and uncertainty over whether the government would support the financial system. Only in the aftermath of the Lehman bankruptcy, increased distress in other asset markets (including MMMFs), and ensuing official liquidity and capital interventions, did deposit inflows become vigorous.

These findings - together with the weak lending growth during the crisis, especially at banks most vulnerable to liquidity drawdowns - suggest that banks were not as able to provide liquidity as would be implied by theory and evidence from other crises. The main reason behind this limitation to banks' role as liquidity backstop was that in the initial phase of the crisis, some banks' funding and solvency were significantly impaired, and eventually resulted in a full-blown banking crisis. The crisis led to blanket government guarantees and only following that did deposits fly to banks as safe havens.

Finally, though we focused on banks in the U.S., due in part to it being the epicenter of the crisis and in part given the better availability of banking data, evidence from Europe and the UK appears to conform to our findings. Given that many large European banks were also exposed to the ABCP freeze starting August of 2007 (Acharya, Schnabl, and Suarez, 2009), the funding risks of these banks were similar to their U.S. counterparts (in most cases worse, as these banks had limited access to the U.S. deposit market and government funding such as FHLB advances). For instance, there was a depositor flight from the European periphery to stronger German banks (perceived to have a stronger government backing them). ${ }^{27}$ Similarly, while many British depositors increased their funds in Irish banks, drawn by higher rates after the Irish government full guarantee was announced in 2008 (roughly 200 euro billion of total 370 euro billion deposits were held by non-residents), several large Irish banks including Bank of Ireland and Allied Irish Banks eventually experienced a deposit flight in November 2010.

\section{References}

Acharya, Viral, 2009, "A Theory of Systemic Risk and Design of Prudential Bank Regulation”, Journal of Financial Stability, 5(3), 224-255.

\footnotetext{
${ }^{27}$ See for example, the New York Times, May 26, 2010, "Doubts Grow on Central Bank's Ability to End Crisis", and the Economist, November 27, 2010, "Plugging the Hole"and December 3, 2011, "The Dash for Cash".
} 
Acharya, Viral, Heitor Almeida and Murillo Campello, 2010, “Aggregate Risk and the Choice Between Cash and Lines of Credit", Working Paper, New York University Stern School of Business.

Acharya, Viral and Ouarda Merrouche, 2008, "Precautionary Hoarding of Liquidity and Inter-Bank Markets: Evidence from the Sub-prime Crisis", Working Paper, New York University Stern School of Business.

Acharya, Viral, Lasse Pedersen, Thomas Philippon and Mathew Richardson, 2010, "Measuring Systemic Risk", Working paper, New York University Stern School of Business.

Acharya, Viral, Joao Santos and Tanju Yorulmazer, 2010, "Systemic Risk and Deposit Insurance Premiums" Economic Policy Review, Federal Reserve Bank of New York, 16(1), 89-99.

Acharya, Viral, Philipp Schnabl, and Gustavo Suarez, 2009, "Securitization without Risk Transfer,"Journal of Financial Economics, forthcoming.

Acharya, Viral and David Skeie, 2011, "A Model of Liquidity Hoarding and Term Premia in Inter-Bank Markets", Journal of Monetary Economics, Carnegie Rochester Series in Public Policy (April 2011), forthcoming.

Adrian, Tobias, Karin Kimbrough and Dina Marchioni, 2010, “The Federal Reserve's Commercial Paper Funding Facility," Federal Reserve Bank of New York Staff Reports no. 423.

Afonso, Gara, Anna Kovner and Antoinette Schoar, 2010, "Stressed, Not Frozen: The Federal Funds Market in the Financial Crisis," Federal Reserve Bank of New York Staff Reports no. 437. Forthcoming Journal of Finance.

Ashcraft, Adam, 2008, “Does the Market Discipline Banks? New Evidence from the Regulatory Capital Mix," Journal of Financial Intermediation, 17(4), 543-561.

Ashcraft, Adam, Morten Bech, and Scott Frame, 2010, "The Federal Home Loan Bank System: the Lender of Nextto-Last Resort?"Journal of Money, Credit and Banking, 42(4), 551-583.

Ashcraft Adam, James McAndrews and David Skeie, 2010, "Precautionary Reserves and the Interbank Market," Journal of Money, Credit and Banking, forthcoming.

Becker, Bo, 2007, “Geographical Segmentation of US Capital Markets” Journal of Financial Economics, 85(1), 151178.

Bord, Vitaly, and Joao Santos, 2011, “Banks' Liquidity and Cost of Liquidity for Corporations," Working Paper, Federal Reserve Bank of New York.

Bertrand, Marianne, Antoinette Schoar and David Thesmar, 2007, "Banking Deregulation and Industry Structure: Evidence from the French Banking Reforms of 1985," The Journal of Finance, 62(2), 597-628.

Borenstein, Severin and Nancy Rose, 1995, "Bankruptcy and Pricing Behavior in U.S. Airline Markets," American Economic Review, 85(2), 397-402.

Brunnermeier, Markus, 2009, “Deciphering the Liquidity and Credit Crunch 2007-2008," Journal of Economic Perspectives, 23(1), 77-100.

Busse, Meghan, 2002, "Firm Financial Condition and Airline Price Wars," The RAND Journal of Economics, 33(2), 298-318. 
Calomiris, Charles, and Berry Wilson, 2004, “Bank Capital and Portfolio Management: The 1930s 'Capital Crunch' and the Scramble to Shed Risk," Journal of Business, 77(3), 421-455.

Chakrabarti , Rajashri, Donghoon Lee, Wilbert van der Klaauw and Basit Zafar, 2011, "Household debt and saving during the 2007 recession" Federal Reserve Bank of New York Staff Reports no. 482.

Cornett, Marcia, Jamie McNutt, Philip Strahan, and Hassan Tehranian, 2011, "Liquidity Risk Management and Credit Supply in the Financial Crisis," Journal of Financial Economics, 101(2), 297-312.

Cook, Douglas, and Lewis Spellman, 1994, "Repudiation Risk and Restitution Costs: Toward Understanding Premiums on Insured Deposits," Journal of Money, Credit and Banking, 26(3), 439-459.

Covitz, Daniel, Nellie Liang, and Gustavo Suarez, 2009, "The Evolution of a Financial Crisis: Panic in the AssetBacked Commercial Paper Market," Finance and Economics Discussion Series, Federal Reserve Board of Governors 2009-36.

Davenport, Andrew and Kathleen McDill, 2006, "The Depositor Behind the Discipline: A Micro-Level Case Study of Hamilton Bank," Journal of Financial Services Research, 30(1), 93-109.

Demirguc-Kunt Asli, and Harry Huizinga, 2004, “Market Discipline and Deposit Insurance," Journal of Monetary Economics, 51(2), 375-399.

Diamond, Douglas, and Raghuram Rajan, 2005, “Liquidity Shortages and Banking Crises," Journal of Finance, 60(2), 615-647.

Diamond, Douglas, and Raghuram Rajan, 2009, "The Credit Crisis: Conjectures about Causes and Remedies," American Economic Review: Papers \& Proceedings, 99(2), 606-610.

Driscoll, John and Ruth Judson, 2009, "Sticky Deposit Rates: Data and Implications for Models of Price Adjustment" Working Paper, Federal Reserve Board.

Federal Reserve Bulletin. 2009 and 2010 issues. Profits and Balance Sheet Developments at U.S. Commercial Banks.

Flannery, Mark, and Sorin Sorescu, 1996, "Evidence of Bank Market Discipline in Subordinated Debenture Yields: 1983-1991," Journal of Finance, 51(4), 1347-1377.

Flannery, Mark, 1998, “Using Market Information in Prudential Bank Supervision: A Review of the U.S. Empirical Evidence," Journal of Money, Credit and Banking, 30(3), 273-305.

Gao, Pengjie, and Hayong Yun, 2009, "Commercial Paper, Lines of Credit, and the Real Effects of the Financial Crisis of 2008: Firm-level Evidence from the Manufacturing Industry," Working Paper, Notre Dame University.

Gatev, Evan, and Philip Strahan, 2006, “Banks' Advantage in Hedging Liquidity Risk: Theory and Evidence from the Commercial Paper Market," Journal of Finance, 61(2), 867-892.

Gatev, Evan, Til Schuermann and Philip Strahan, 2009, “Managing Bank Liquidity Risk: How Deposit-Loan Synergies Vary with Market Conditions," Review of Financial Studies, 22(3), 995-1020.

Goldberg, Lawrence, and Sylvia Hudgins, 2002, "Depositor Discipline and Changing Strategies for Regulating Thrift Institutions," Journal of Financial Economics, 63(2), 263-274. 
Gorton, Gary, 2008, "The Panic of 2007," in Maintaining Stability in a Changing Financial System, a symposium sponsored by the Federal Reserve Bank of Kansas City, August 21-23.

Gozzi, Juan Carlos and Martin Goetz, 2010, "Liquidity Shocks, Local Banks, and Economic Activity: Evidence from the 2007-2009 Crisis", Working Paper, Brown University.

Hannan, Timothy, and Gerald Hanweck, 1988, "Bank Insolvency Risk and the Market for Large Certificates of Deposit," Journal of Money, Credit and Banking, 20(2), 203-211.

He, Zhiguo, In Gu Khang, and Arvind Krishnamurthy. 2010. "Balance Sheet Adjustments during the 2008 Crisis," Working Paper, University of Chicago.

Ivashina, Victoria, and David Scharfstein, 2010, "Bank Lending during the Financial Crisis of 2008," Journal of Financial Economics, 97(3), 319-338.

Iyer, Rajkamal and Manju Puri, 2008, "Understanding Bank Runs: The Importance of Depositor-Bank Relationships and Networks," NBER Working Paper 14280.

Kacperczyk, Marcin, and Philipp Schnabl, 2010, "When Safe Proved Risky: Commercial Paper during the Financial Crisis of 2007-2009," Journal of Economic Perspectives, 24(1), 29-50.

Kacperczyk, Marcin and Philipp Schnabl, 2011, "Implicit Guarantees and Risk Taking: Evidence from Money Market Funds," Working paper, New York University Stern School of Business.

Kashyap, Anil, Raghuram Rajan and Jeremy Stein, 2002, "Banks as Liquidity Providers: An Explanation for the Coexistence of Lending and Deposit-Taking," Journal of Finance, 57(1), 33-73.

Liu, Yian, 2011, "International Liquidity Sharing: Evidence from Financial Crises", Working Paper, University of Chicago.

Maechler, Andrea, and Kathleen McDill, 2006, "Dynamic depositor discipline in US banks," Journal of Banking and Finance, 30(7), 1871-1898.

Martinez Peria, Maria Soledad, and Sergio Schmukler, 2001, "Do Depositors Punish Banks for Bad Behavior? Market Discipline, Deposit Insurance, and Banking Crises," Journal of Finance, 56(3), 1029-1051.

McCabe, Patrick, 2010, "The Cross Section of Money Market Fund Risks and Financial Crises" Finance and Economics Discussion Series, Federal Reserve Board of Governors, 2010-51.

Montoriol-Garriga, Judit, and Evan Sekeris, 2009, “A Question of Liquidity: The Great Banking Run of 2008?” Federal Reserve Bank of Boston Working Paper No QAU09-4.

Mora, Nada, 2010, “Can Banks Provide Liquidity in a Financial Crisis?” Economic Review, Federal Reserve Bank of Kansas City, Third Quarter.

Park, Sangkyun, and Stavros Peristiani, 1998, "Market Discipline by Thrift Depositors," Journal of Money, Credit and Banking, 30(3), 347-364.

Pennacchi, George. 2006. "Deposit Insurance, Bank Regulation, and Financial System Risks," Journal of Monetary Economics, 53(1), 1-30.

Rajan, Raghuram, 2005, “Has Financial Development Made the World Riskier?" in The Greenspan Era: Lessons for the Future, a symposium sponsored by the Federal Reserve Bank of Kansas City, August 25-27. 
Saidenberg, Marc, and Philip Strahan, 1999, “Are Banks Still Important for Financing Large Businesses?” Federal Reserve Bank of New York Current Issues in Economics and Finance, 5(12), 1-6.

Saunders, Anthony, and Berry Wilson, 1996, "Contagious Bank Runs: Evidence from the 1929-1933 Period," Journal of Financial Intermediation, 5(4), 409-423.

Schumacher, Liliana, 2000, "Bank Runs and Currency Runs in a System without a Safety Net: Argentina and the 'Tequila' Shock," Journal of Monetary Economics, 46(1), 257-277.

Shapiro, Matthew, 2010, "The Effects of the Financial Crisis on the Well-Being of Older Americans: Evidence from the Cognitive Economics Study," Working Paper, University of Michigan. 


\section{Chart 1. Relative Deposit Rates of Failed Banks}

These two charts plot the deposit rates of failed banks (and nearly failed banks) adjusted for the rates of banks that did not fail over the period 1997-2009. The underlying data are current rates from a weekly survey from Bank Rate Monitor (BRM), available from 1997. The top panel is for all failed banks with available BRM data, and the lower panel focuses on four prominent financial institutions that failed (IndyMac, Washington Mutual) or nearly failed Wachovia, Citi) in the crisis. Specifically, relative rates in Chart 1a are the average of the difference between rates for 43 failed banks (FDIC regulatory-assisted failures and CRSP near-fails) and rates of non-fail banks. Note that following Acharya, Pedersen, Philippon and Richardson (2010), these near-fails correspond to the first date when the 18-month return was worse than -90\% using daily CRSP equity data (e.g., the result was September 29, 2008 for Wachovia, which was also the date that its acquisition was announced). The $\mathrm{x}$-axis is the time to failure in weeks. The failure date is the last available weekly (Friday) survey date prior to failure.

\section{Chart 1a}

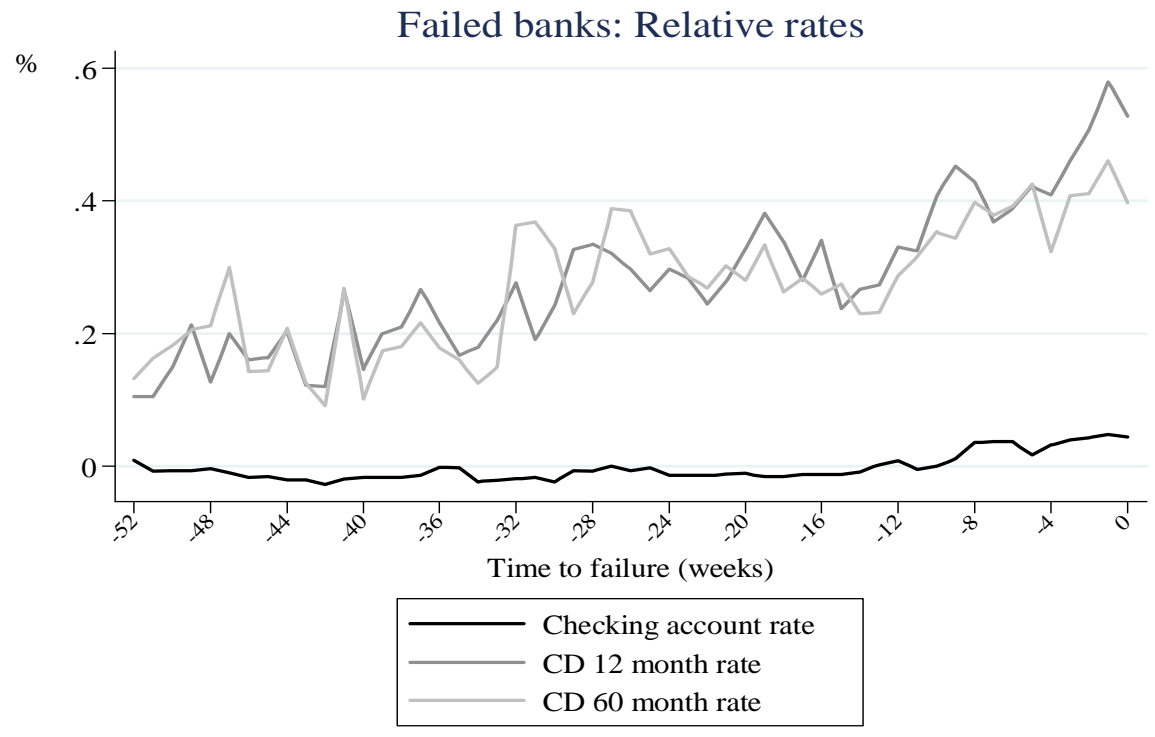

Chart 1b

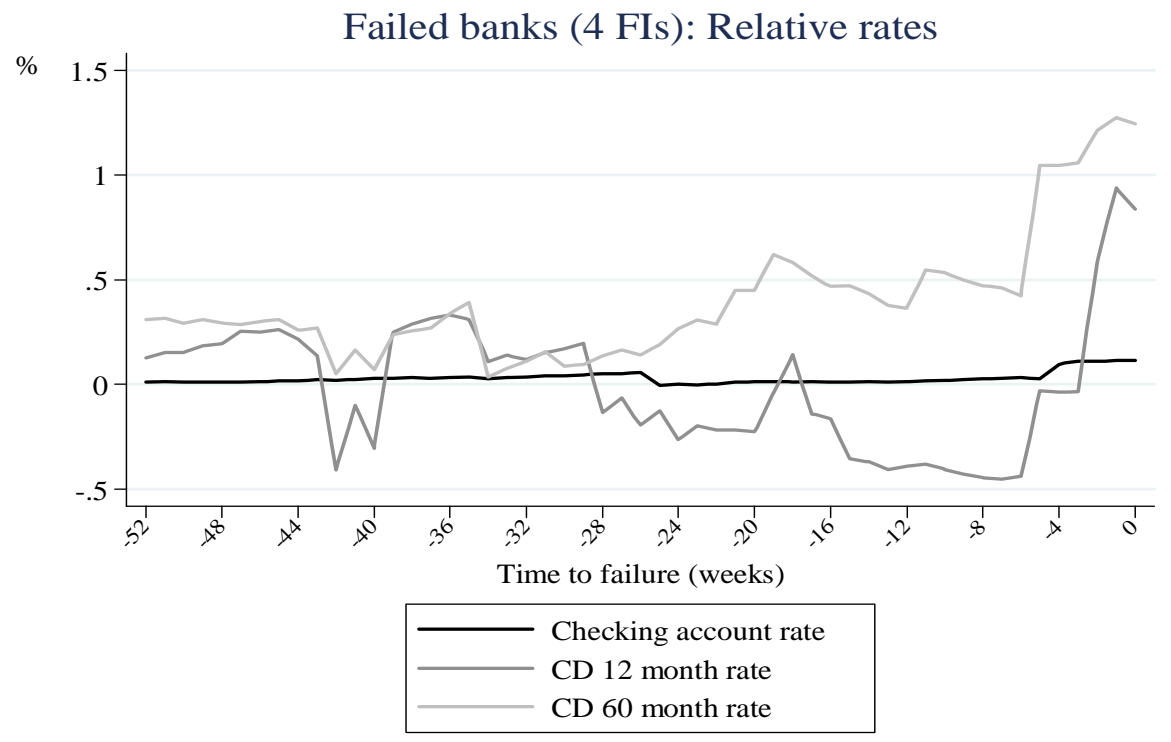




\section{Chart 2. Insured and Uninsured Deposits of Failed Banks}

These two charts plot insured and uninsured deposits at failed banks (and nearly failed banks) over the period 1990-2009. The underlying deposit data are from the quarterly Call Reports, which include over 500 bank failures. The $\mathrm{x}$-axis is the time to failure in quarters, where failure covers both regulatory-assisted failures and near-fails, as measured by large negative returns on the market value of equity (specifically, the first date when the 18-month return was worse than $-90 \%$ using daily CRSP data following Acharya, Pedersen, Philippon, and Richardson, 2010). Chart 2a plots average insured and uninsured deposit growth at failed banks, and similarly Chart $2 \mathrm{~b}$ plots the ratio of insured and uninsured deposits to beginning of period assets; plots account for mergers and the change in insured deposit reporting thresholds in 2009:Q3. Also shown in Chart $2 \mathrm{~b}$ are the average deposit ratios for banks that did not fail, which are plotted over the period 2007:Q1 to 2009:Q1, where 2009:Q1 also corresponds to the quarter with the most failures over the sample period.

\section{Chart 2a}

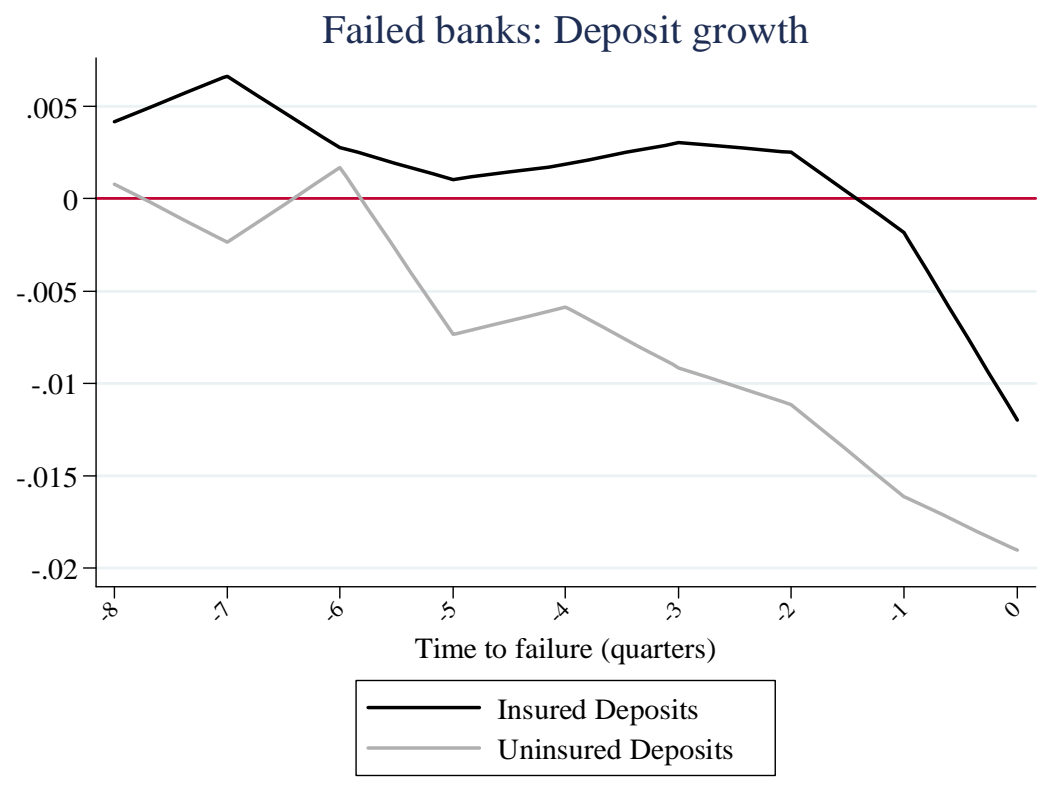

Chart 2b

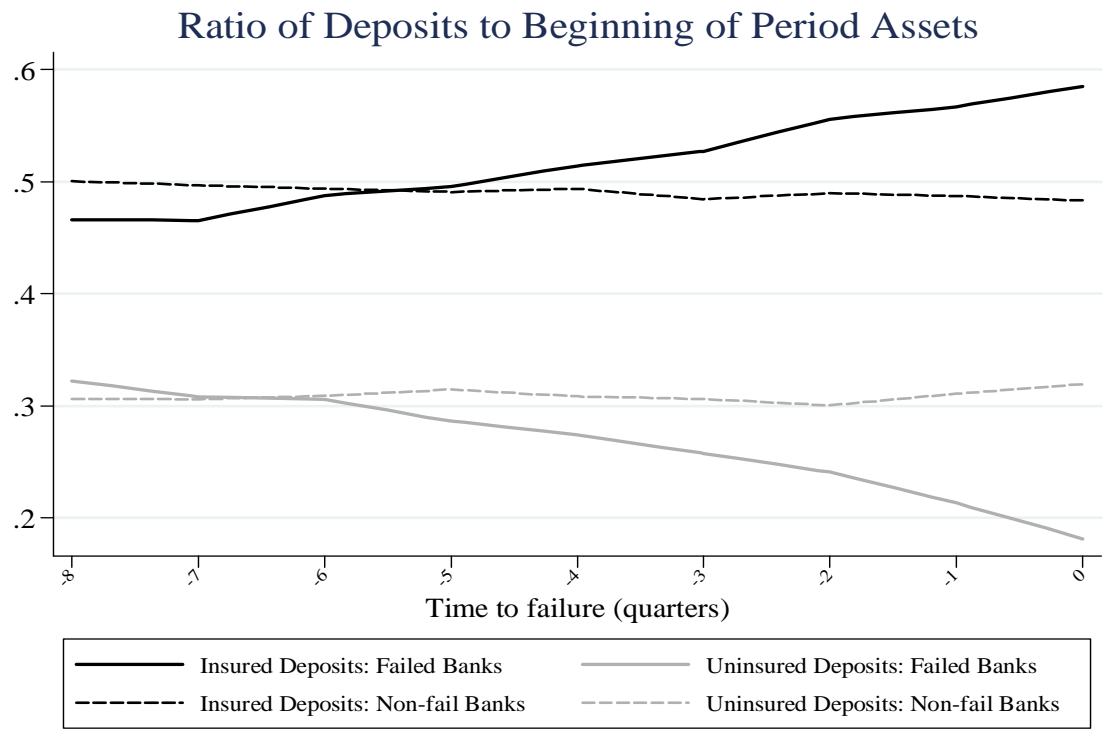




\section{Chart 3. Equilibrium Deposit Rates and Quantities Panel A. Illustrating the Effect of an Increase in a Bank's Riskiness}

This chart plots the joint determination of deposit rates and quantities as the outcome of depositors' "demand" (the upward sloping curve) and bank "supply" (the downward sloping curve).

An increase in a bank's riskiness is expected to shift both curves as illustrated. First, depositors are thought to discipline banks for risk-taking behavior by withdrawing funds from deposit accounts, as well as by demanding higher deposit rates. Second, banks exposed to liquidity demand shocks and at a greater risk of insolvency actively seek deposits by raising rates.

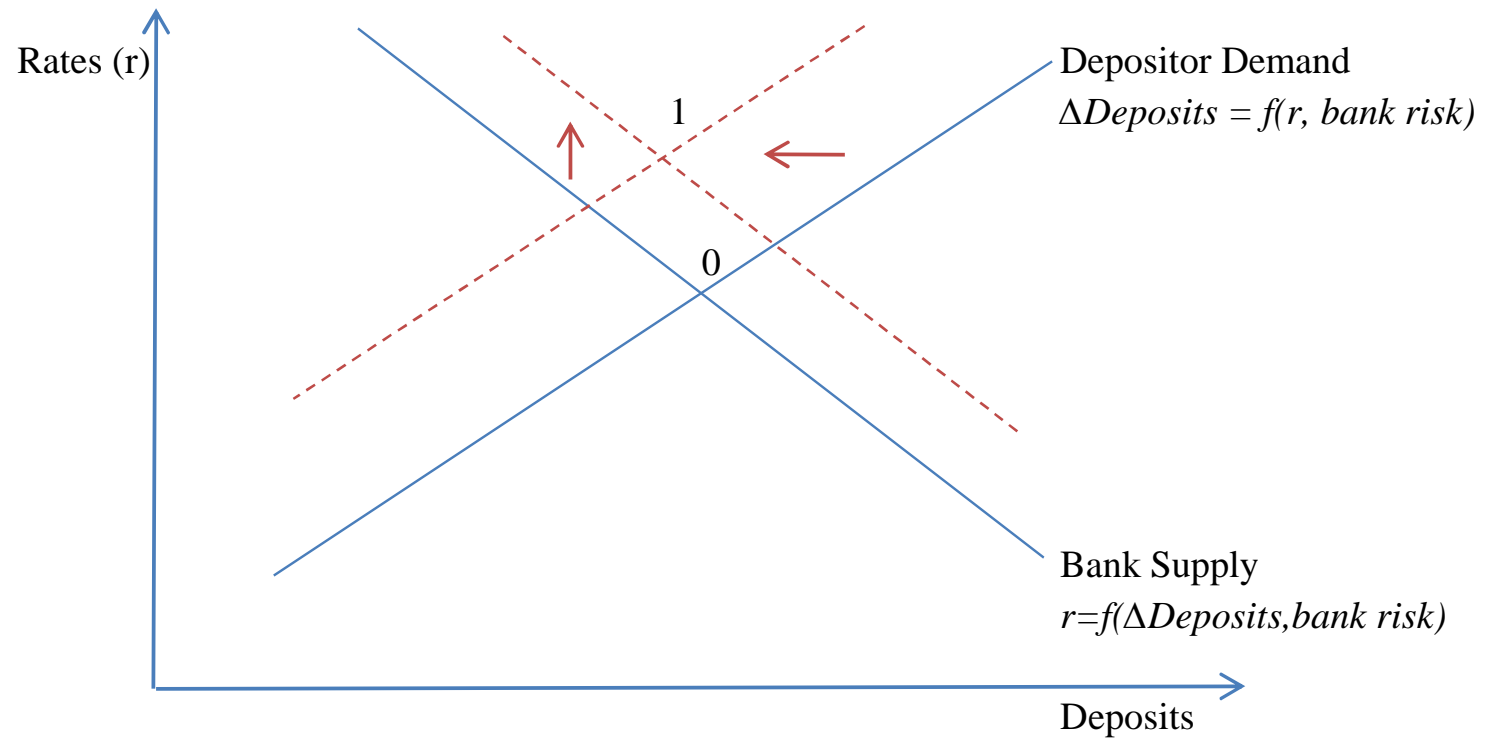

\section{Panel B. Illustrating the Identification Strategy}

This chart illustrates our method for identifying the bank supply curve. We use the share of deposits in a bank's local geographic market belonging to failed banks as an instrument for a bank's contemporaneous deposit inflows. This variable is constructed using information on dates of bank failures together with branch-level deposit data from the Summary of Deposits. Exogenous shifts in depositor demand stemming from local market bank failures thus identify the bank supply curve. A similar strategy is employed to identify the depositor demand curve: We use exogenous shifts in the cost of funds from alternative sources (e.g., the LIBOR spread).

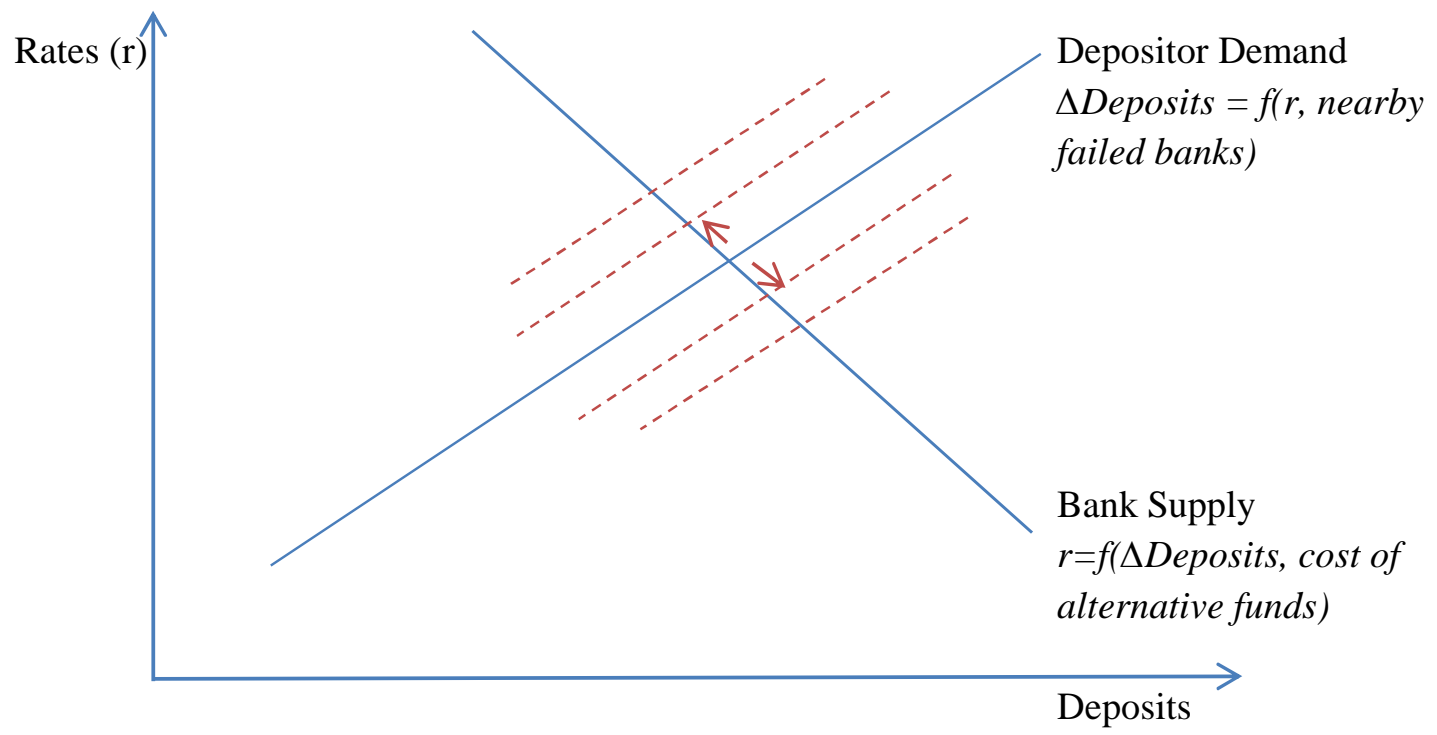




\section{Chart 4. VIX and Net Flows into Deposits at Commercial Banks}

This chart plots the VIX index (left-axis) and net flows into deposit accounts at commercial banks (right-axis) over the period 2005-2009. The underlying data are the Chicago Board Options Exchange for VIX (month-end), and the Federal Reserve H8 release for deposits at domestically chartered commercial banks. The latter deposit flows data are aggregated from weekly to monthly frequency. These deposit flows are also corrected for the artificial impact of JP Morgan Chase's acquisition of the large thrift, WaMu, reflected in the H8 release of October 1, 2008.

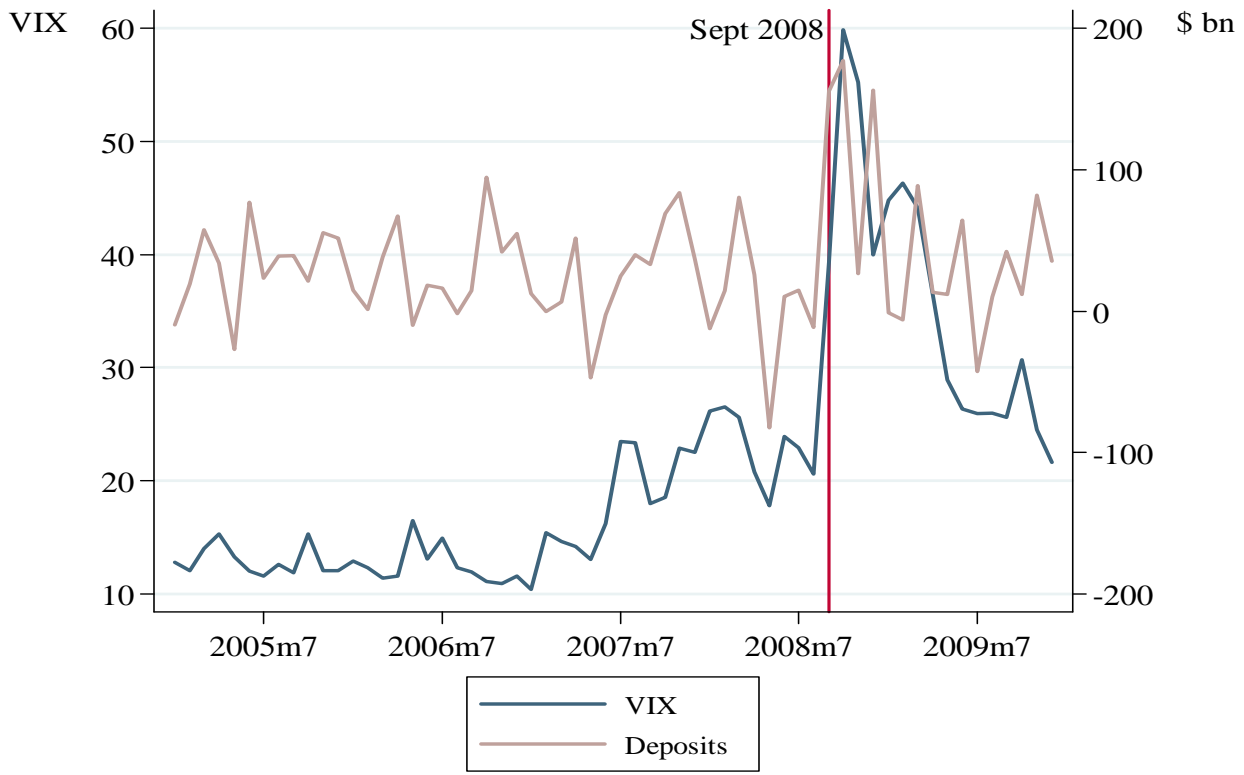

\section{Chart 5. Net Flows into Deposits at Commercial Banks:}

Large and Small Banks, Core and Large-Time Deposits

This chart plots net flows into deposit accounts at commercial banks over the period 2005-2009, disaggregated by large and small banks, and by core and large-time deposits. The underlying data are the Federal Reserve $\mathrm{H} 8$ release for deposits at domestically chartered commercial banks. The latter deposit flows data are aggregated from weekly to monthly frequency. Large banks in the H8 release are the largest 25. For example, inclusion as of mid-2009 was $\$ 65$ billion asset size. Combined, large banks held $66 \%$ of domestically chartered assets and $60 \%$ of deposits. The deposit flows at the large banks are also corrected for the artificial impact of JP Morgan Chase's acquisition of the large thrift, WaMu, reflected in the H8 release of October 1, 2008.

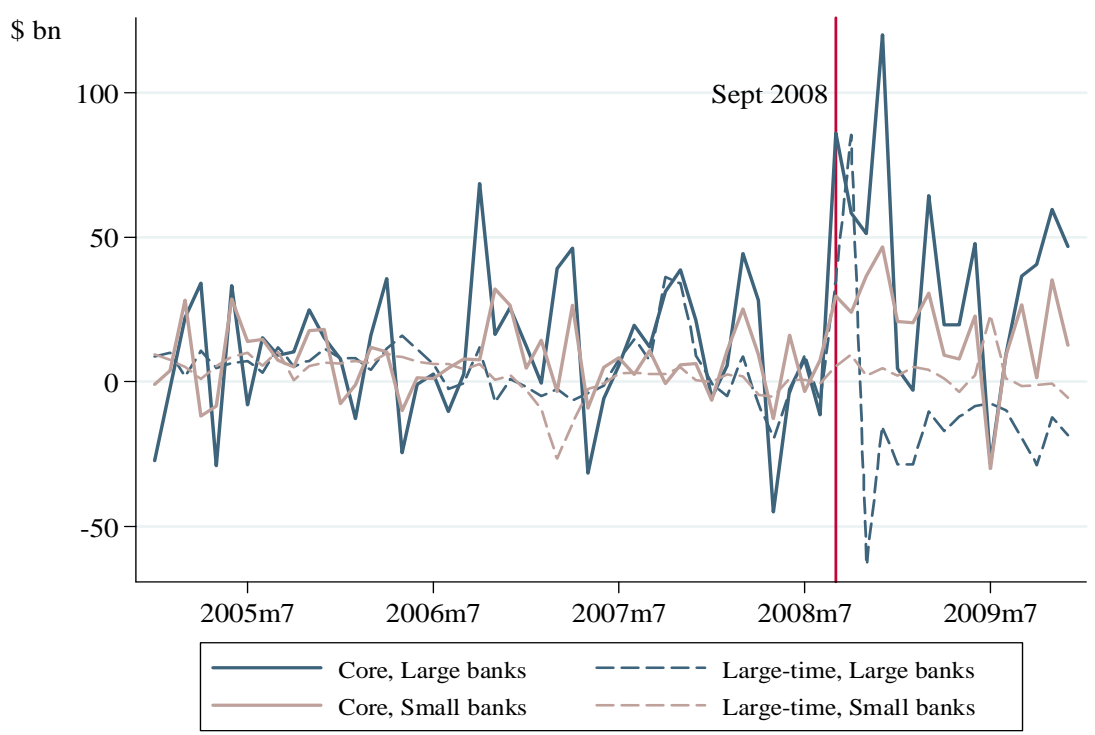




\section{Chart 6. Cumulative Growth of Balance Sheet Components}

These two charts plot the cumulative growth of key balance sheet assets and liabilities at the weekly frequency from July 2007 through the end of 2009 (growth figures are relative to the first week of July 2007).The four key series are total deposits, non-deposit borrowing, loans and leases, and liquid assets (the sum of cash assets, securities, and interbank loans extended). Panel A is for large domestically chartered banks and Panel B is for small domestically chartered banks. The underlying data are the Federal Reserve H8 release for deposits at domestically chartered commercial banks. Large banks in the H8 release are the largest 25. For example, inclusion as of mid-2009 was $\$ 65$ billion asset size. Combined, large banks held $66 \%$ of domestically chartered assets and $60 \%$ of deposits. The balance sheet series at the large banks are also corrected for the artificial impact of JP Morgan's acquisition of the large thrift, WaMu, reflected in the H8 release of October 1, 2008.

\section{Panel A}

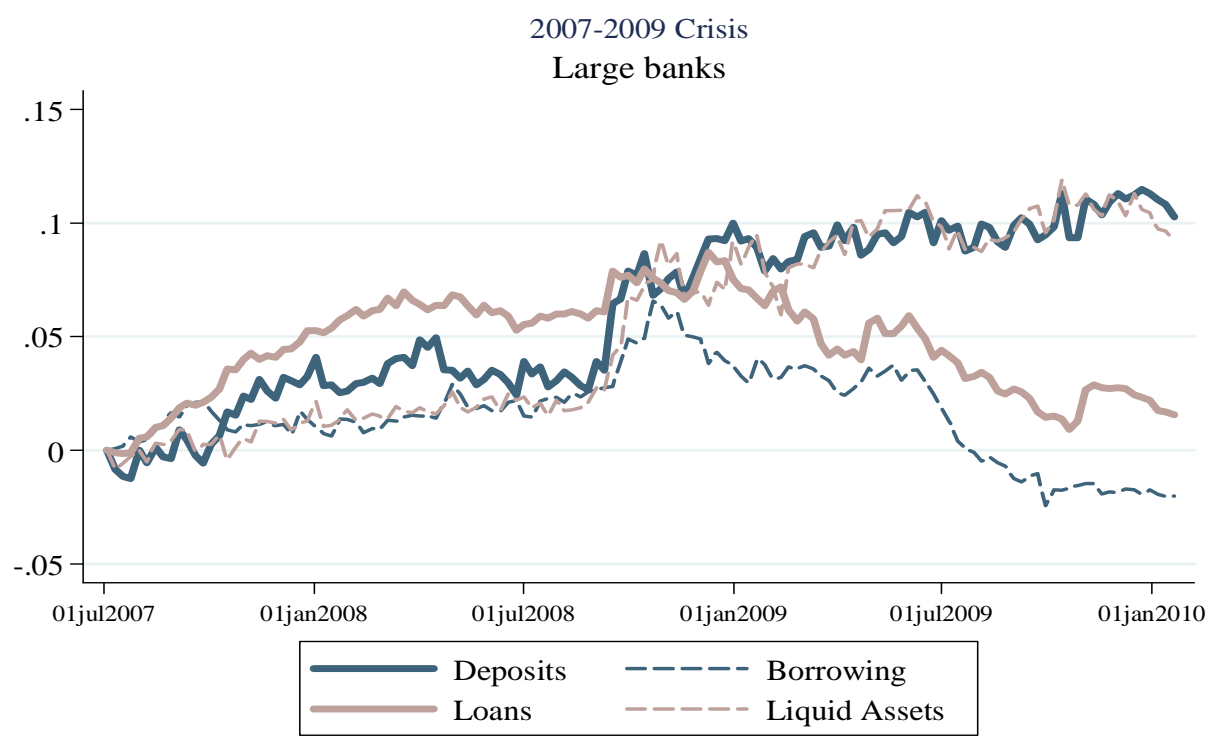

Source: Federal Reserve H8 release

Panel B

2007-2009 Crisis

Small banks

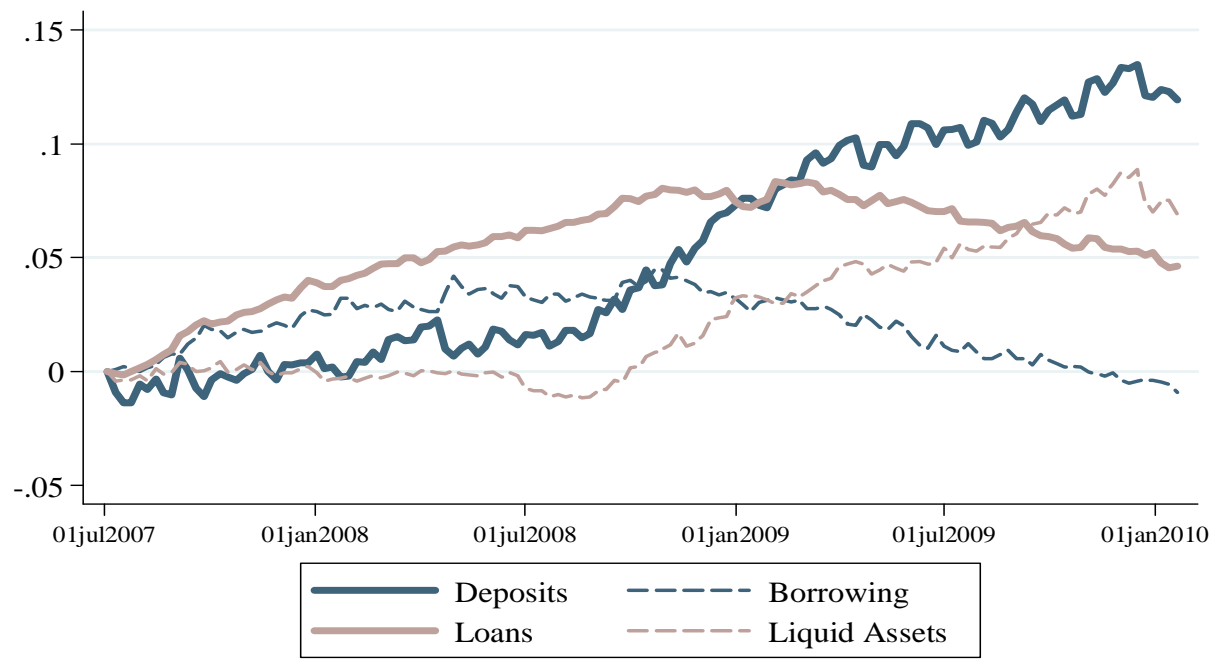

Source: Federal Reserve H8 release 
Table 1. Cumulative Deposit Growth During the 2007-2009 Financial Crisis (in \%)

2007Q3 2007Q4 2008Q1 2008Q2 $2008 \mathrm{Q} 3 \quad 2008 \mathrm{Q} 4 \quad 2009 \mathrm{Q} 1$

Panel A. Large Banks (Largest 25 banks, H8 criteria)

Insured deposits

$0.1 \quad 0.8$

Core deposits

$0.2 \quad 2.4$

Large time deposits

$0.6 \quad 1.5 \quad 1.8$

$1.7 \quad 1.7$

$1.7 \quad 3.9$

$\begin{array}{lll}3.9 & 4.6 & 5.6\end{array}$

Panel B. Small Banks

Insured deposits

Core deposits

Large time deposits

$\begin{array}{rrrrrrr}0.0 & 0.0 & 0.7 & 1.0 & 2.3 & 3.0 & 2.0 \\ -0.4 & -0.7 & -0.7 & -0.5 & 0.0 & 0.9 & 0.5 \\ 1.7 & 2.4 & 3.4 & 3.8 & 2.7 & -0.2 & -0.1\end{array}$

All Banks, Core

$\underbrace{\$ 767}_{\$ 90 \text { billion }} \underbrace{\text { billion }}_{\$ 272 \text { billion }}$

All Banks, Large-Time

$\underbrace{-\$ 172 \text { billion }}_{\text {\$53 billion }}$

This table shows an extract of cumulative growth statistics for certain deposit accounts based on the quarterly Call Reports over the period from 2007:Q3 to 2009:Q1 (see Appendix Table A2 for full balance sheet detail). Panel A shows the growth in insured deposits, core deposits, and large-time deposits over the period relative to initial 2007:Q2 levels for large banks. Similarly, Panel B shows the deposit growth figures for small banks, and the bottom panel summarizes overall deposit inflows into the banking system in billions of dollars over the period 2007:Q4-2009:Q1. These aggregate flow of funds match the data reported in He, Khang, and Krishnamurthy (2010) for the corresponding period (where core deposits are reported to have increased by roughly $\$ 800$ billion, while large-time deposits decreased by $\$ 200$ billion). 
Table 2. Deposit Interest Rates and Deposit Flows in the Run-up to Bank Failures

Formal Fails are regulatory-assisted failures, where the FDIC is typically appointed the receiver of the failed bank. CRSP Fails are the period associated with market equity returns worse than -90\% over 18-month period (Acharya et al, 2010).

Panel A.

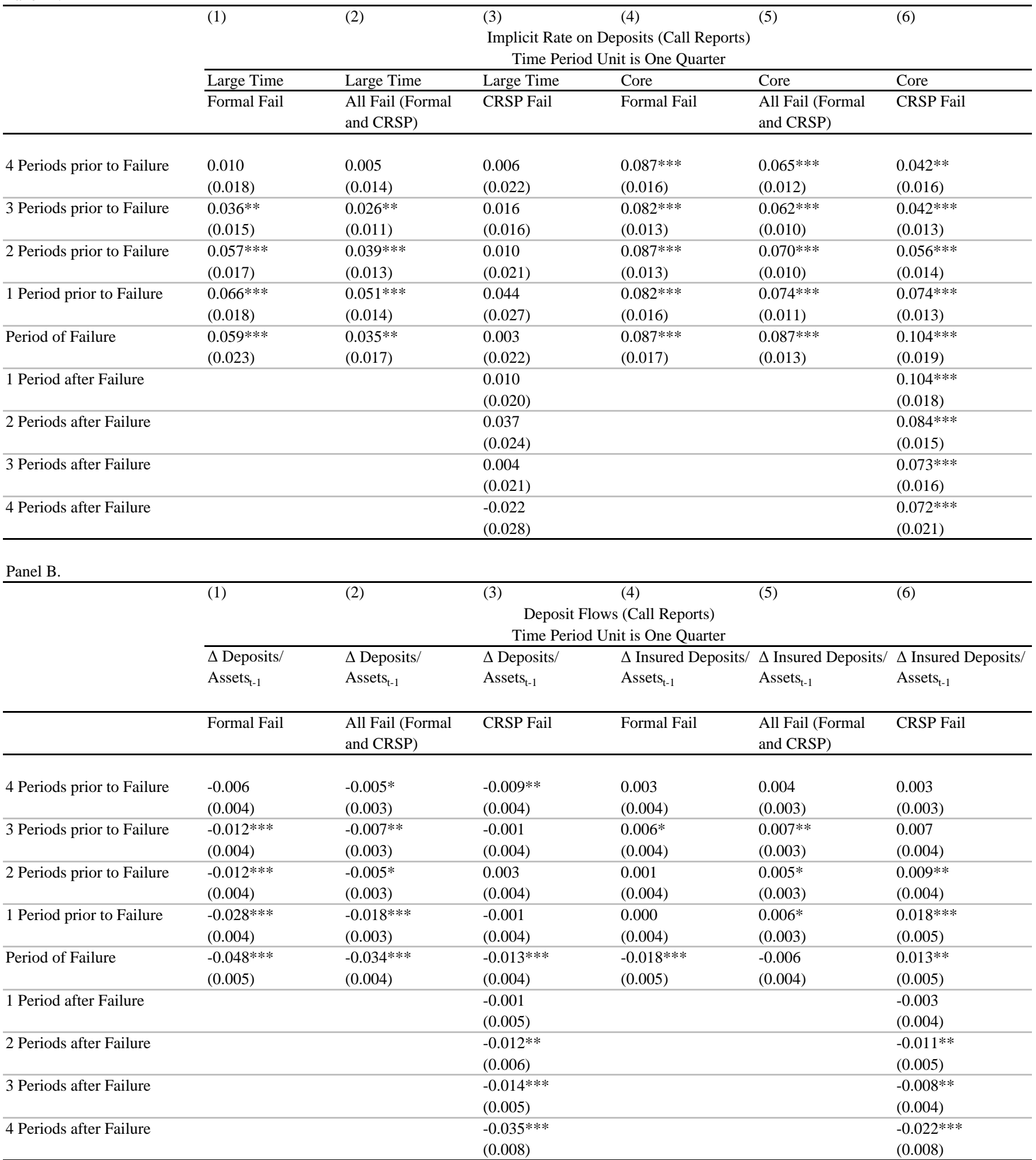

The sample period of the regressions is from 1994 to 2009, using quarterly Call Report data.

All specifications are panel regressions with fixed effects for bank organizations and time dummies (quarterly).

All regressions control for the deposit-weighted geographic market deposit concentration (annual from Summary of Deposits), and for District time trends.

The standard errors used in calculating significance levels are clustered at the bank organization level.

See Appendix for variable definitions and details about bank panel. ***, **, * indicate $1 \%, 5 \%$, and $10 \%$ significance, respectively. 
Table 3. The Relationship between the Deposit Interest Rate and Bank Risk Characteristics in the Crisis (Allowing for Two Phases of the Crisis: 2007Q3-2008Q2 and 2008Q3-2009Q2)

Implicit Rate on Deposits (Call Reports)

\begin{tabular}{|c|c|c|c|c|}
\hline & $\begin{array}{l}\text { (1) } \\
\text { Large Time }\end{array}$ & $\begin{array}{l}\text { (2) } \\
\text { Large Time } \\
\end{array}$ & $\begin{array}{l}3) \\
\text { Core } \\
\end{array}$ & $\begin{array}{l}(4) \\
\text { Core } \\
\end{array}$ \\
\hline \multicolumn{5}{|l|}{ Liquidity measures } \\
\hline Unused commitment ratio $\mathrm{t}_{\mathrm{t}-1}$ & $\begin{array}{l}0.027 \\
(0.025)\end{array}$ & $\begin{array}{l}-0.231^{* * *} \\
(0.029)\end{array}$ & $\begin{array}{l}-0.074 * * * \\
(0.021)\end{array}$ & $\begin{array}{l}-0.461 * * * \\
(0.031)\end{array}$ \\
\hline Unused commitment ratio $\mathrm{t}_{\mathrm{t}-1} \times$ Crisis1 & $\begin{array}{l}0.144 * * * \\
(0.030)\end{array}$ & $\begin{array}{l}0.178 * * * \\
(0.038)\end{array}$ & $\begin{array}{l}-0.011 \\
(0.027)\end{array}$ & $\begin{array}{l}0.186^{* * *} \\
(0.057)\end{array}$ \\
\hline Unused commitment ratio $\mathrm{t}_{\mathrm{t}-1} \times$ Crisis2 & $\begin{array}{l}-0.167^{* * *} \\
(0.035)\end{array}$ & $\begin{array}{l}-0.217^{* * * *} \\
(0.040)\end{array}$ & $\begin{array}{l}-0.175^{* * * *} \\
(0.027)\end{array}$ & $\begin{array}{l}-0.150^{* * * *} \\
(0.044)\end{array}$ \\
\hline Liquidity ratio $_{\mathrm{t}-1}$ & $\begin{array}{l}-0.043^{* * *} \\
(0.016)\end{array}$ & $\begin{array}{l}-0.114^{* * *} \\
(0.018)\end{array}$ & $\begin{array}{l}-0.039 * * * \\
(0.012)\end{array}$ & $\begin{array}{l}-0.183^{* * *} \\
(0.019)\end{array}$ \\
\hline Liquidity ratio $_{\mathrm{t}-1} \times$ Crisis1 & $\begin{array}{l}0.017 \\
(0.021)\end{array}$ & $\begin{array}{l}0.040 \\
(0.025)\end{array}$ & $\begin{array}{l}-0.112 * * * \\
(0.022)\end{array}$ & $\begin{array}{l}-0.146 * * * \\
(0.028)\end{array}$ \\
\hline Liquidity ratio ${ }_{\mathrm{t}-1} \times$ Crisis2 & $\begin{array}{l}-0.042^{*} \\
(0.023)\end{array}$ & $\begin{array}{l}-0.030 \\
(0.027)\end{array}$ & $\begin{array}{l}-0.082^{* * *} \\
(0.016)\end{array}$ & $\begin{array}{l}-0.088 * * * \\
(0.026)\end{array}$ \\
\hline Wholesale funding $g_{t-1}$ & $\begin{array}{l}0.124 * * * \\
(0.018)\end{array}$ & $\begin{array}{l}0.123^{* * *} \\
(0.016)\end{array}$ & $\begin{array}{l}-0.068 * * * \\
(0.017)\end{array}$ & $\begin{array}{l}0.257 * * * \\
(0.020)\end{array}$ \\
\hline Wholesale funding $_{t-1} \times$ Crisis1 & $\begin{array}{l}0.032 * \\
(0.019)\end{array}$ & $\begin{array}{l}0.096 * * * \\
(0.021)\end{array}$ & $\begin{array}{l}0.125^{* * *} \\
(0.020)\end{array}$ & $\begin{array}{l}0.139 * * * \\
(0.028)\end{array}$ \\
\hline Wholesale funding $\mathrm{t}_{-1} \times$ Crisis2 & $\begin{array}{l}-0.060^{* * *} \\
(0.023)\end{array}$ & $\begin{array}{l}0.006 \\
(0.027)\end{array}$ & $\begin{array}{l}0.081^{* * *} \\
(0.020)\end{array}$ & $\begin{array}{l}0.084^{* * * *} \\
(0.028)\end{array}$ \\
\hline \multicolumn{5}{|l|}{ Solvency measures } \\
\hline NPL to Loans ${ }_{\mathrm{t}-1}$ & $\begin{array}{l}0.210^{* * *} \\
(0.061)\end{array}$ & $\begin{array}{l}0.216^{* * * *} \\
(0.082)\end{array}$ & $\begin{array}{l}0.053 \\
(0.043)\end{array}$ & $\begin{array}{l}0.412 * * * \\
(0.092)\end{array}$ \\
\hline NPL to Loans ${ }_{t-1} \times$ Crisis1 & $\begin{array}{l}-0.131 \\
(0.116)\end{array}$ & $\begin{array}{l}0.045 \\
(0.130)\end{array}$ & $\begin{array}{l}0.194 * * * \\
(0.064)\end{array}$ & $\begin{array}{l}0.443^{*} \\
(0.229)\end{array}$ \\
\hline NPL to Loans ${ }_{t-1} \times$ Crisis2 & $\begin{array}{l}0.319 * * * \\
(0.078)\end{array}$ & $\begin{array}{l}0.450 * * * \\
(0.100)\end{array}$ & $\begin{array}{l}0.278 * * * \\
(0.051)\end{array}$ & $\begin{array}{l}0.468 * * * \\
(0.112)\end{array}$ \\
\hline Capital ratio $\mathrm{t}-1_{1}$ & $\begin{array}{l}-0.256^{* *} \\
(0.101)\end{array}$ & $\begin{array}{l}0.009 \\
(0.094)\end{array}$ & $\begin{array}{l}-0.513^{* * *} \\
(0.084)\end{array}$ & $\begin{array}{l}0.093 \\
(0.095)\end{array}$ \\
\hline Capital ratio $_{\mathrm{t}-1} \times$ Crisis1 & $\begin{array}{l}0.461^{* * *} \\
(0.087)\end{array}$ & $\begin{array}{l}0.479 * * * \\
(0.110)\end{array}$ & $\begin{array}{l}0.161 \\
(0.124)\end{array}$ & $\begin{array}{l}0.091 \\
(0.171)\end{array}$ \\
\hline Capital ratio $_{\mathrm{t}-1} \times$ Crisis2 & $\begin{array}{l}0.083 \\
(0.126)\end{array}$ & $\begin{array}{l}-0.038 \\
(0.141)\end{array}$ & $\begin{array}{l}0.013 \\
(0.083)\end{array}$ & $\begin{array}{l}-0.179 \\
(0.138)\end{array}$ \\
\hline Risk-based capital ratio $_{\mathrm{t}-1}$ & $\begin{array}{l}0.029 \\
(0.054)\end{array}$ & $\begin{array}{l}-0.053 \\
(0.050)\end{array}$ & $\begin{array}{l}-0.001 \\
(0.031)\end{array}$ & $\begin{array}{l}-0.025 \\
(0.045)\end{array}$ \\
\hline Risk-based capital ratio $_{\mathrm{t}-1} \times$ Crisis1 & $\begin{array}{l}-0.201^{* * *} \\
(0.054)\end{array}$ & $\begin{array}{l}-0.240^{* * *} \\
(0.080)\end{array}$ & $\begin{array}{l}-0.052 \\
(0.090)\end{array}$ & $\begin{array}{l}-0.015 \\
(0.098)\end{array}$ \\
\hline Risk-based capital ratio $_{\mathrm{t}-1} \times$ Crisis2 & $\begin{array}{l}-0.134 \\
(0.094)\end{array}$ & $\begin{array}{l}-0.114 \\
(0.077)\end{array}$ & $\begin{array}{l}0.047 \\
(0.044)\end{array}$ & $\begin{array}{l}0.051 \\
(0.076)\end{array}$ \\
\hline Large Bank Indicator & $\begin{array}{l}-0.019 \\
(0.032)\end{array}$ & $\begin{array}{l}-0.056 \\
(0.037)\end{array}$ & $\begin{array}{l}0.005 \\
(0.026)\end{array}$ & $\begin{array}{l}-0.099 * * * \\
(0.024)\end{array}$ \\
\hline Large Bank Indicator $\times$ Crisis1 & $\begin{array}{l}-0.046 \\
(0.035)\end{array}$ & $\begin{array}{l}-0.061 \\
(0.043)\end{array}$ & $\begin{array}{l}-0.080^{* * *} \\
(0.018)\end{array}$ & $\begin{array}{l}-0.167 * * * \\
(0.024)\end{array}$ \\
\hline Large Bank Indicator $\times$ Crisis2 & $\begin{array}{l}-0.038 \\
(0.027)\end{array}$ & $\begin{array}{l}-0.039 \\
(0.039)\end{array}$ & $\begin{array}{l}-0.012 \\
(0.018)\end{array}$ & $\begin{array}{l}-0.040^{*} \\
(0.024)\end{array}$ \\
\hline Bank Fixed Effects & Yes & No & Yes & No \\
\hline Observations & 176427 & 176427 & 176459 & 176459 \\
\hline $\mathrm{R}^{2}$ & 0.76 & 0.73 & 0.89 & 0.76 \\
\hline
\end{tabular}

The sample period of the regressions is from 1996 to 2009, using quarterly Call Report data.

All specifications are panel regressions with fixed effects for bank organizations and quarterly time dummies (unless otherwise noted).

The reported $\mathrm{R}^{2}$ is the within $\mathrm{R}^{2}$. All regressions control for District time trends and for the deposit-weighted geographic market deposit concentration (annual from Summary of Deposits). Crisis 1 is a dummy variable equal to 1 from 2007Q3 to 2008Q2, and Crisis 2 is a dummy variable equal to 1 from 2008Q3 to 2009Q2.

The standard errors used in calculating significance levels are clustered at the bank organization level.

See Appendix for variable definitions and details about bank panel. ***,**, * indicate $1 \%, 5 \%$, and $10 \%$ significance, respectively. 
Table 4. The Relationship between Deposit Inflows and Bank Risk Characteristics in the Crisis (Allowing for Two Phases of the Crisis: 2007Q3-2008Q2 and 2008Q3-2009Q2)

\begin{tabular}{|c|c|c|c|c|}
\hline & $\begin{array}{l}(1) \\
\Delta \text { Deposits/ } \\
\text { Assets }_{\mathrm{t}-1}\end{array}$ & $\begin{array}{l}(2) \\
\Delta \text { Core Deposits/ } \\
\text { Assets }_{\mathrm{t}-1}\end{array}$ & $\begin{array}{l}\text { (3) } \\
\Delta \text { Brokered Deposits/ } \\
\text { Assets }_{\mathrm{t}-1}\end{array}$ & $\begin{array}{l}\text { (4) } \\
\text { TAG Deposits } \\
\text { (2008Q4)/ } \\
\text { Assets }_{\mathrm{t}-1}\end{array}$ \\
\hline \multicolumn{5}{|l|}{ Liquidity measures } \\
\hline Unused commitment ratio $\mathrm{t}_{\mathrm{t}-1}$ & $\begin{array}{l}0.040^{* * * *} \\
(0.004)\end{array}$ & $\begin{array}{l}0.028 * * * \\
(0.004)\end{array}$ & $\begin{array}{l}0.009 * * * \\
(0.001)\end{array}$ & $\begin{array}{l}0.189 * * * \\
(0.017)\end{array}$ \\
\hline Unused commitment ratio $\mathrm{t}_{\mathrm{t}-1} \times$ Crisis1 & $\begin{array}{l}-0.009 \\
(0.006)\end{array}$ & $\begin{array}{l}-0.008 \\
(0.006)\end{array}$ & $\begin{array}{l}0.006 * * \\
(0.003)\end{array}$ & \\
\hline Unused commitment ratio $\mathrm{t}_{\mathrm{t}-1} \times$ Crisis2 & $\begin{array}{l}0.022 * * * \\
(0.007)\end{array}$ & $\begin{array}{l}0.012 * * \\
(0.005)\end{array}$ & $\begin{array}{l}0.017 * * * \\
(0.002)\end{array}$ & \\
\hline Liquidity ratio $\mathrm{t}_{\mathrm{t}-1}$ & $\begin{array}{l}-0.088^{* * * *} \\
(0.002)\end{array}$ & $\begin{array}{l}-0.062 * * * \\
(0.002)\end{array}$ & $\begin{array}{l}-0.008^{* * *} \\
(0.001)\end{array}$ & $\begin{array}{l}0.047 * * * \\
(0.010)\end{array}$ \\
\hline Liquidity ratio $\mathrm{t}_{\mathrm{t}-1} \times$ Crisis 1 & $\begin{array}{l}0.013^{* * *} \\
(0.004)\end{array}$ & $\begin{array}{l}0.012^{* * *} \\
(0.003)\end{array}$ & $\begin{array}{l}-0.004^{* * *} \\
(0.001)\end{array}$ & \\
\hline Liquidity ratio $_{\mathrm{t}-1} \times$ Crisis2 & $\begin{array}{l}-0.017^{* * *} \\
(0.004)\end{array}$ & $\begin{array}{l}-0.003 \\
(0.004)\end{array}$ & $\begin{array}{l}-0.007^{* * * *} \\
(0.001)\end{array}$ & \\
\hline Wholesale funding $\mathrm{t}_{\mathrm{t}-1}$ & $\begin{array}{l}0.050 * * * \\
(0.003)\end{array}$ & $\begin{array}{l}0.079 * * * \\
(0.003)\end{array}$ & $\begin{array}{l}0.008 * * * \\
(0.001)\end{array}$ & $\begin{array}{l}-0.010 \\
(0.013)\end{array}$ \\
\hline Wholesale funding $\mathrm{t}_{\mathrm{t}-1} \times$ Crisis1 & $\begin{array}{l}-0.002 \\
(0.004)\end{array}$ & $\begin{array}{l}0.018^{* * * *} \\
(0.003)\end{array}$ & $\begin{array}{l}0.001 \\
(0.002)\end{array}$ & \\
\hline Wholesale funding $_{\mathrm{t}-1} \times$ Crisis2 & $\begin{array}{l}0.008 * * \\
(0.004)\end{array}$ & $\begin{array}{l}0.028 * * * \\
(0.003)\end{array}$ & $\begin{array}{l}0.005^{* * * *} \\
(0.002)\end{array}$ & \\
\hline \multicolumn{5}{|l|}{ Solvency measures } \\
\hline NPL to Loans ${ }_{\mathrm{t}-1}$ & $\begin{array}{l}-0.194^{* * * *} \\
(0.015)\end{array}$ & $\begin{array}{l}-0.139 * * * \\
(0.012)\end{array}$ & $\begin{array}{l}-0.045^{* * * *} \\
(0.004)\end{array}$ & $\begin{array}{l}0.054 \\
(0.041)\end{array}$ \\
\hline NPL to Loans ${ }_{t-1} \times$ Crisis1 & $\begin{array}{l}0.008 \\
(0.016)\end{array}$ & $\begin{array}{l}0.020 \\
(0.015)\end{array}$ & $\begin{array}{l}0.018^{*} \\
(0.010)\end{array}$ & \\
\hline NPL to Loans ${ }_{t-1} \times$ Crisis2 & $\begin{array}{l}0.069 * * * \\
(0.020)\end{array}$ & $\begin{array}{l}0.051 * * * \\
(0.016)\end{array}$ & $\begin{array}{l}0.007 \\
(0.006)\end{array}$ & \\
\hline Capital ratio $_{\mathrm{t}-1}$ & $\begin{array}{l}0.189 * * * \\
(0.018)\end{array}$ & $\begin{array}{l}0.173 * * * \\
(0.014)\end{array}$ & $\begin{array}{l}0.020 * * * \\
(0.005)\end{array}$ & $\begin{array}{l}0.003 \\
(0.054)\end{array}$ \\
\hline Capital ratio $_{\mathrm{t}-1} \times$ Crisis1 & $\begin{array}{l}-0.008 \\
(0.020)\end{array}$ & $\begin{array}{l}0.017 \\
(0.018)\end{array}$ & $\begin{array}{l}0.006 \\
(0.005)\end{array}$ & \\
\hline Capital ratio $_{\mathrm{t}-1} \times$ Crisis2 & $\begin{array}{l}0.012 \\
(0.020)\end{array}$ & $\begin{array}{l}0.015 \\
(0.018)\end{array}$ & $\begin{array}{l}0.028 * * * \\
(0.006)\end{array}$ & \\
\hline Risk-based capital ratio $_{\mathrm{t}-1}$ & $\begin{array}{l}-0.007^{*} \\
(0.004)\end{array}$ & $\begin{array}{l}-0.006 \\
(0.004)\end{array}$ & $\begin{array}{l}0.0000 \\
(0.001)\end{array}$ & $\begin{array}{l}-0.023 \\
(0.029)\end{array}$ \\
\hline Risk-based capital ratio $_{\mathrm{t}-1} \times$ Crisis1 & $\begin{array}{l}0.032^{* *} \\
(0.013)\end{array}$ & $\begin{array}{l}0.012 \\
(0.011)\end{array}$ & $\begin{array}{l}-0.0005 \\
(0.003)\end{array}$ & \\
\hline Risk-based capital ratio $_{\mathrm{t}-1} \times$ Crisis2 & $\begin{array}{l}0.052 * * * \\
(0.015)\end{array}$ & $\begin{array}{l}0.036 * * * \\
(0.013)\end{array}$ & $\begin{array}{l}-0.005^{*} \\
(0.003)\end{array}$ & \\
\hline Large Bank Indicator & $\begin{array}{l}-0.006^{*} \\
(0.003)\end{array}$ & $\begin{array}{l}-0.005 * * \\
(0.003)\end{array}$ & $\begin{array}{l}-0.001 \\
(0.001)\end{array}$ & $\begin{array}{l}0.018^{*} \\
(0.009)\end{array}$ \\
\hline Large Bank Indicator × Crisis1 & $\begin{array}{l}0.010^{* * * *} \\
(0.003)\end{array}$ & $\begin{array}{l}0.003 \\
(0.003)\end{array}$ & $\begin{array}{l}-0.0004 \\
(0.001)\end{array}$ & \\
\hline Large Bank Indicator $\times$ Crisis2 & $\begin{array}{l}-0.005 \\
(0.005)\end{array}$ & $\begin{array}{l}0.008^{* *} \\
(0.003)\end{array}$ & $\begin{array}{l}-0.006^{* * * *} \\
(0.001)\end{array}$ & \\
\hline Bank Fixed Effects & Yes & Yes & Yes & No \\
\hline Observations & 176903 & 176903 & 176903 & 3519 \\
\hline $\mathrm{R}^{2}$ & 0.08 & 0.08 & 0.04 & 0.13 \\
\hline
\end{tabular}

The sample period of the regressions is from 1996 to 2009, using quarterly Call Report data.

Specifications in columns (1) to (3) are panel regressions with fixed effects for bank organizations. The reported $\mathrm{R}^{2}$ is the within $\mathrm{R}^{2}$. The specification in column (4) is cross-sectional for 2008Q4 when the Transaction Account Guarantee (TAG) was introduced. Also controlled for in column (4) is the share of transaction deposits. Regressions control for District time trends and for the deposit-weighted geographic market deposit concentration (annual from Summary of Deposits). Crisis 1 is a dummy variable equal to 1 from 2007Q3 to 2008Q2, and Crisis 2 is a dummy variable equal to 1 from 2008Q3 to 2009Q2. The standard errors used in calculating significance levels are clustered at the bank organization level. See Appendix for variable definitions and details about bank panel. ***, **, * indicate $1 \%, 5 \%$, and $10 \%$ significance, respectively. 
Table 5. The Joint Determination of a Bank's Deposit Rates and Flows: An IV Approach (Allowing for Two Phases of the Crisis: 2007Q3-2008Q2 and 2008Q3-2009Q2)

Panel A. Instrumenting for deposit inflows in the interest rate equation (identifying "Bank Supply")

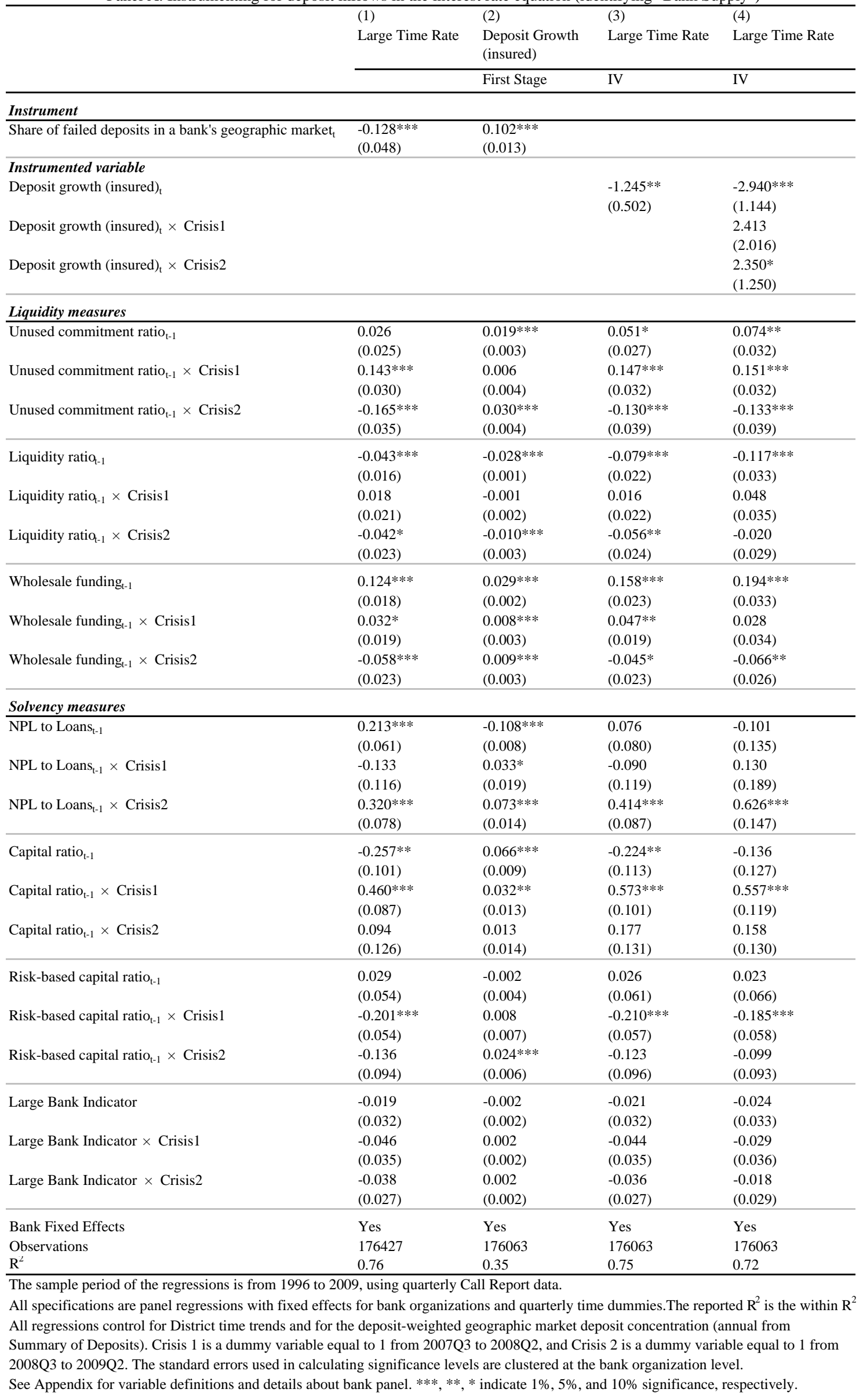


Table 5. The Joint Determination of a Bank's Deposit Rates and Flows: An IV Approach (Allowing for Two Phases of the Crisis: 2007Q3-2008Q2 and 2008Q3-2009Q2)

Panel B. Instrumenting for the deposit rate in the deposit inflows equation (identifying "Depositor Demand")

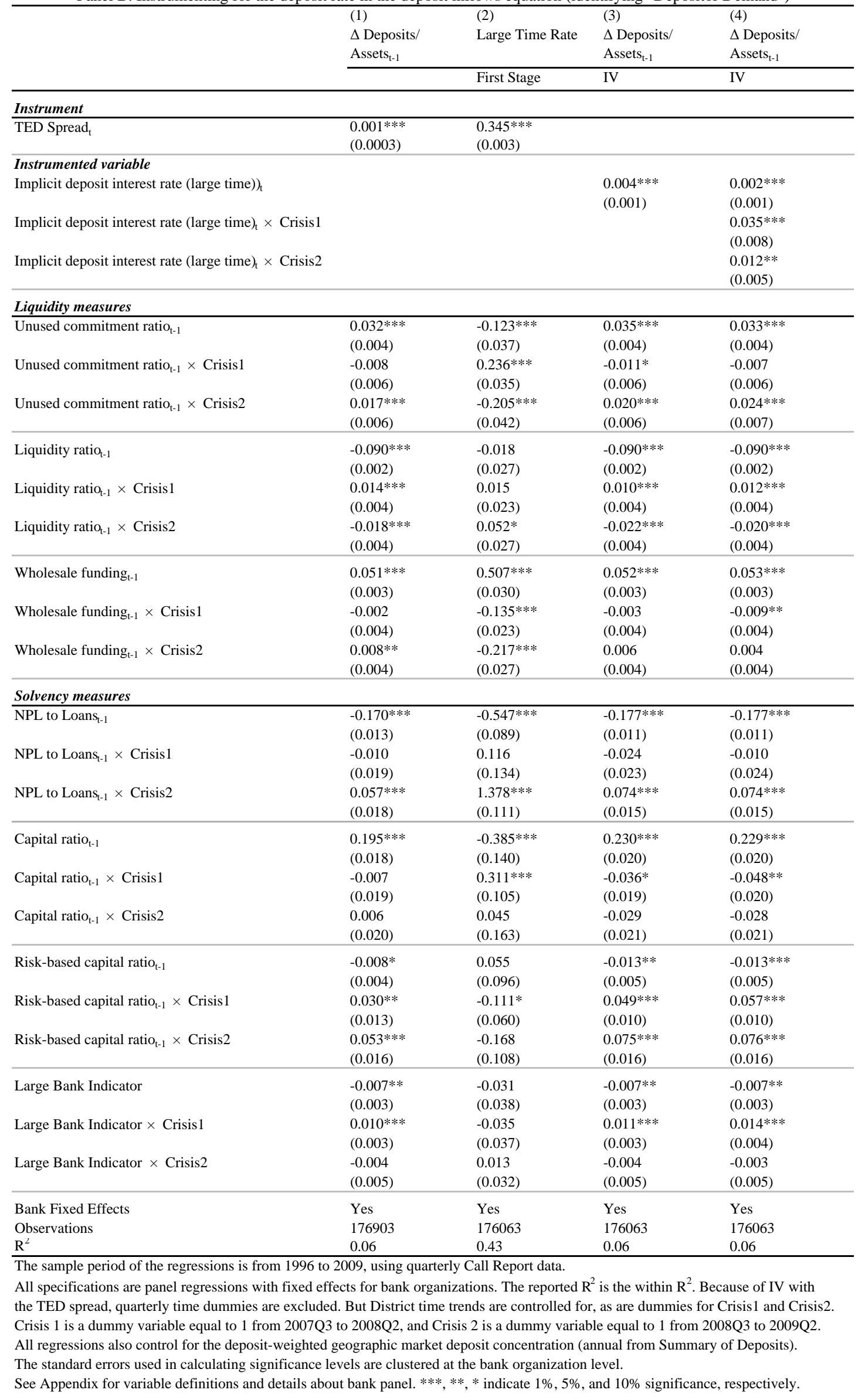


Table 6. Industry Equilibrium: The Interdependence between Banks' Deposit Rates

(Allowing for Two Phases of the Crisis: 2007Q3-2008Q2 and 2008Q3-2009Q2)

Panel A. Large Time Deposit Rate

\begin{tabular}{|c|c|c|c|c|c|c|}
\hline & $(1)$ & $(2)$ & $(3)$ & $(4)$ & $(5)$ & (6) \\
\hline \multirow{2}{*}{$\begin{array}{l}\text { Share of failed deposits in a bank's geographic market (Fail- } \\
\text { share) })_{t}\end{array}$} & $-0.260 * * *$ & & & & & \\
\hline & $(0.067)$ & & & & & \\
\hline \multirow[t]{2}{*}{$(\text { Fail-share })_{\mathrm{t}+1}$} & $-0.298 * * *$ & & & & & \\
\hline & $(0.068)$ & & & & & \\
\hline \multirow[t]{2}{*}{$(\text { Fail-share })_{\mathrm{t}+2}$} & -0.030 & & & & & \\
\hline & $(0.059)$ & & & & & \\
\hline \multirow{2}{*}{$(\text { Fail-share })_{t+3}$} & $0.220 * * *$ & & & & & \\
\hline & $(0.055)$ & & & & & \\
\hline \multirow{2}{*}{$(\text { Fail-share })_{t+4}$} & $0.338 * * *$ & & & & & \\
\hline & $(0.055)$ & & & & & \\
\hline \multirow{2}{*}{ Average large time deposit rate of other banks $\left(\mathrm{r}_{\mathrm{t}}^{\text {other }}\right)$} & & $0.989 * * *$ & & $0.998 * * *$ & & $1.093 * * *$ \\
\hline & & $(0.004)$ & & $(0.007)$ & & $(0.015)$ \\
\hline \multirow{2}{*}{$\mathrm{r}_{\mathrm{t}}^{\text {other }} \times$ Crisis 1} & & $0.056^{* * *}$ & & $0.129 * * *$ & & $0.246 * * *$ \\
\hline & & $(0.015)$ & & $(0.029)$ & & $(0.066)$ \\
\hline \multirow{2}{*}{$\mathrm{r}_{\mathrm{t}}^{\text {other }} \times$ Crisis 2} & & -0.004 & & -0.039 & & 0.042 \\
\hline & & $(0.016)$ & & $(0.030)$ & & $(0.070)$ \\
\hline \multirow[t]{2}{*}{ Deposit concentration in a bank's geographic market $\left(\mathrm{HHI}_{\mathrm{t}}\right)$} & $-0.090 * * *$ & $-0.074 * *$ & $-0.071^{* *}$ & -0.024 & $-0.065 * *$ & $-0.061^{* *}$ \\
\hline & $(0.034)$ & $(0.029)$ & $(0.029)$ & $(0.043)$ & $(0.030)$ & $(0.030)$ \\
\hline \multirow[t]{2}{*}{$\mathrm{HHI}_{\mathrm{t}} \times$ Crisis 1} & & & -0.008 & $0.457 * * *$ & & \\
\hline & & & $(0.018)$ & $(0.148)$ & & \\
\hline \multirow[t]{2}{*}{$\mathrm{HHI}_{\mathrm{t}} \times$ Crisis2 } & & & 0.005 & -0.164 & & \\
\hline & & & $(0.017)$ & $(0.112)$ & & \\
\hline \multirow{2}{*}{$\mathrm{HHI}_{\mathrm{t}} \times \mathrm{r}_{\mathrm{t}}^{\text {other }}$} & & & & -0.047 & & \\
\hline & & & & $(0.030)$ & & \\
\hline \multirow{2}{*}{$\mathrm{HHI}_{\mathrm{t}} \times \mathrm{r}_{\mathrm{t}}^{\text {other }} \times$ Crisis 1} & & & & $-0.407 * * *$ & & \\
\hline & & & & $(0.131)$ & & \\
\hline \multirow{2}{*}{$\mathrm{HHI}_{\mathrm{t}} \times \mathrm{r}_{\mathrm{t}}^{\text {other }} \times$ Crisis 2} & & & & 0.193 & & \\
\hline & & & & $(0.135)$ & & \\
\hline \multirow{2}{*}{$\begin{array}{l}\text { Seniors as share of population in a bank's geographic market } \\
\left(\text { Senior }_{t}\right)\end{array}$} & & & & & -0.324 & $0.663 * * *$ \\
\hline & & & & & $(0.217)$ & $(0.249)$ \\
\hline \multirow[t]{2}{*}{ Senior $_{t} \times$ Crisis 1} & & & & & $-0.307 * * *$ & $1.446^{* * *}$ \\
\hline & & & & & $(0.058)$ & $(0.538)$ \\
\hline \multirow[t]{2}{*}{ Senior $_{\mathrm{t}} \times$ Crisis 2} & & & & & $-0.121^{*}$ & 0.060 \\
\hline & & & & & $(0.063)$ & $(0.415)$ \\
\hline \multirow{2}{*}{ Senior $_{t} \times r_{t}^{\text {other }}$} & & & & & & $-0.774 * * *$ \\
\hline & & & & & & $(0.106)$ \\
\hline \multirow{2}{*}{ Senior $_{t} \times r_{t}^{\text {other }} \times$ Crisis1 } & & & & & & $-1.419 * * *$ \\
\hline & & & & & & $(0.474)$ \\
\hline \multirow{2}{*}{ Senior $_{t} \times r_{t}^{\text {other }} \times$ Crisis2 } & & & & & & -0.323 \\
\hline & & & & & & $(0.505)$ \\
\hline Local conditions controls & & & & & & \\
\hline Percentage change in house prices in a bank's geographic market ${ }_{t}$ & $-0.197 * * *$ & $-0.091^{* *}$ & $-0.201^{* * *}$ & $-0.086 * *$ & $-0.204 * * *$ & $-0.096 * * *$ \\
\hline & $(0.053)$ & $(0.037)$ & $(0.047)$ & $(0.037)$ & $(0.047)$ & $(0.037)$ \\
\hline Percentage change in employment in a bank's geographic market ${ }_{t}$ & 0.029 & $0.106 * * *$ & 0.023 & $0.102^{* * *}$ & 0.021 & $0.094 * * *$ \\
\hline & $(0.023)$ & $(0.020)$ & $(0.021)$ & $(0.020)$ & $(0.021)$ & $(0.020)$ \\
\hline Percentage change in establishments in a bank's geographic & $-0.126 * * *$ & $-0.110 * * *$ & $-0.122 * * *$ & $-0.106^{* * *}$ & $-0.122 * * *$ & $-0.107 * * *$ \\
\hline market $_{\mathrm{t}}$ & $(0.026)$ & $(0.023)$ & $(0.023)$ & $(0.023)$ & $(0.023)$ & $(0.023)$ \\
\hline Bank Fixed Effects & Yes & Yes & Yes & Yes & Yes & Yes \\
\hline Observations & 151006 & 176350 & 176350 & 176350 & 176350 & 176350 \\
\hline $\mathrm{R}^{2}$ & 0.76 & 0.76 & 0.76 & 0.76 & 0.76 & 0.76 \\
\hline
\end{tabular}

The sample period of the regressions is from 1996 to 2009, using quarterly Call Report data.

All specifications are panel regressions with fixed effects for bank organizations. All specifications control for the bank-level liquidity and solvency measures in Table 3 (not shown). The reported $\mathrm{R}^{2}$ is the within $\mathrm{R}^{2}$. Columns (1), (3), and (5) control for quarterly time dummies. Columns (2), (4), and (6) exclude quarterly time dummies. In the latter, District time trends are controlled for, as are Crisis1 and Crisis2 dummies. Crisis 1 is a dummy variable equal to 1 from 2007Q3 to 2008Q2, and Crisis 2 is a dummy variable equal to 1 from 2008 Q3 to 2009 Q2. All regressions also control for the deposit-weighted geographic market deposit concentration (annual from Summary of Deposits). The standard errors used in calculating significance levels are clustered at the bank organization level.

See Appendix for variable definitions and details about bank panel. ***, **, * indicate 1\%, 5\%, and 10\% significance, respectively. 
Table 6. Industry Equilibrium: The Interdependence between Banks' Deposit Rates

(Allowing for Two Phases of the Crisis: 2007Q3-2008Q2 and 2008Q3-2009Q2)

Panel B. Core Deposit Rate

\begin{tabular}{|c|c|c|c|c|c|c|}
\hline & (1) & (2) & (3) & (4) & (5) & (6) \\
\hline \multirow{4}{*}{$\begin{array}{l}\text { Share of failed deposits in a bank's geographic market (Fail- } \\
\text { share) })_{t} \\
\text { (Fail-share) })_{t+1}\end{array}$} & -0.015 & & & & & \\
\hline & $(0.052)$ & & & & & \\
\hline & -0.076 & & & & & \\
\hline & $(0.048)$ & & & & & \\
\hline \multirow[t]{2}{*}{$(\text { Fail-share })_{t+2}$} & 0.001 & & & & & \\
\hline & $(0.044)$ & & & & & \\
\hline \multirow[t]{2}{*}{$(\text { Fail-share })_{t+3}$} & 0.051 & & & & & \\
\hline & $(0.040)$ & & & & & \\
\hline \multirow[t]{2}{*}{$(\text { Fail-share })_{t+4}$} & $0.097 * *$ & & & & & \\
\hline & $(0.045)$ & & & & & \\
\hline \multirow[t]{2}{*}{ Average core deposit rate of other banks $\left(\mathrm{r}_{\mathrm{t}}^{\text {other }}\right)$} & & $0.998 * * *$ & & $0.992 * * *$ & & $1.024 * * *$ \\
\hline & & $(0.003)$ & & $(0.006)$ & & $(0.013)$ \\
\hline \multirow{2}{*}{$\mathrm{r}_{\mathrm{t}}^{\text {other }} \times$ Crisis 1} & & $0.070 * * *$ & & $0.170^{* * * *}$ & & $0.336 * * *$ \\
\hline & & $(0.010)$ & & $(0.020)$ & & $(0.046)$ \\
\hline \multirow{2}{*}{$\mathrm{r}_{\mathrm{t}}^{\text {other }} \times$ Crisis2 } & & -0.015 & & 0.029 & & 0.042 \\
\hline & & $(0.011)$ & & $(0.020)$ & & $(0.046)$ \\
\hline \multirow[t]{2}{*}{ Deposit concentration in a bank's geographic market $\left(\mathrm{HHI}_{\mathrm{t}}\right)$} & 0.027 & 0.029 & 0.036 & 0.004 & 0.037 & 0.036 \\
\hline & $(0.028)$ & $(0.023)$ & $(0.023)$ & $(0.029)$ & $(0.024)$ & $(0.024)$ \\
\hline \multirow[t]{2}{*}{$\mathrm{HHI}_{\mathrm{t}} \times$ Crisis 1} & & & $-0.047^{* * *}$ & $0.393 * * *$ & & \\
\hline & & & $(0.012)$ & $(0.070)$ & & \\
\hline \multirow[t]{2}{*}{$\mathrm{HHI}_{\mathrm{t}} \times$ Crisis2 } & & & $-0.035 * * *$ & $0.103^{* *}$ & & \\
\hline & & & $(0.013)$ & $(0.050)$ & & \\
\hline \multirow{2}{*}{$\mathrm{HHI}_{\mathrm{t}} \times \mathrm{r}_{\mathrm{t}}^{\text {other }}$} & & & & 0.039 & & \\
\hline & & & & $(0.023)$ & & \\
\hline \multirow{2}{*}{$\mathrm{HHI}_{\mathrm{t}} \times \mathrm{r}_{\mathrm{t}}^{\text {other }} \times$ Crisis 1} & & & & $-0.564 * * *$ & & \\
\hline & & & & $(0.089)$ & & \\
\hline \multirow{2}{*}{$\mathrm{HHI}_{\mathrm{t}} \times \mathrm{r}_{\mathrm{t}}^{\text {other }} \times$ Crisis2 } & & & & $-0.246^{* * *}$ & & \\
\hline & & & & $(0.088)$ & & \\
\hline \multirow{2}{*}{$\begin{array}{l}\text { Seniors as share of population in a bank's geographic market } \\
\left(\text { Senior }_{t}\right)\end{array}$} & & & & & $-0.311^{*}$ & -0.123 \\
\hline & & & & & $(0.180)$ & $(0.203)$ \\
\hline \multirow[t]{2}{*}{ Senior $_{t} \times$ Crisis 1} & & & & & $-0.088^{*}$ & $1.515^{* * *}$ \\
\hline & & & & & $(0.046)$ & $(0.251)$ \\
\hline \multirow[t]{2}{*}{ Senior $_{\mathrm{t}} \times$ Crisis 2} & & & & & -0.041 & 0.171 \\
\hline & & & & & $(0.048)$ & $(0.181)$ \\
\hline \multirow{2}{*}{ Senior $_{t} \times r_{t}^{\text {other }}$} & & & & & & $-0.194 * *$ \\
\hline & & & & & & $(0.087)$ \\
\hline \multirow{2}{*}{ Senior $_{t} \times r_{t}^{\text {other }} \times$ Crisis 1} & & & & & & $-1.994 * * *$ \\
\hline & & & & & & $(0.321)$ \\
\hline \multirow[t]{2}{*}{ Senior $_{t} \times r_{t}^{\text {other }} \times$ Crisis2 } & & & & & & -0.417 \\
\hline & & & & & & $(0.325)$ \\
\hline \multicolumn{7}{|l|}{ Local conditions controls } \\
\hline Percentage change in house prices in a bank's geographic market $_{t}$ & $-0.204 * * *$ & $-0.195 * * *$ & $-0.218 * * *$ & $-0.190 * * *$ & $-0.234 * * *$ & $-0.198 * * *$ \\
\hline & $(0.044)$ & $(0.031)$ & $(0.040)$ & $(0.030)$ & $(0.040)$ & $(0.031)$ \\
\hline Percentage change in employment in a bank's geographic market ${ }_{t}$ & -0.018 & $0.081 * * *$ & -0.018 & $0.083 * * *$ & -0.019 & $0.079 * * *$ \\
\hline & $(0.014)$ & $(0.014)$ & $(0.013)$ & $(0.014)$ & $(0.013)$ & $(0.014)$ \\
\hline Percentage change in establishments in a bank's geographic & $-0.028 *$ & -0.014 & $-0.039 * *$ & -0.016 & $-0.038 * *$ & -0.014 \\
\hline market $_{\mathrm{t}}$ & $(0.017)$ & $(0.016)$ & $(0.016)$ & $(0.016)$ & $(0.016)$ & $(0.016)$ \\
\hline Bank Fixed Effects & Yes & Yes & Yes & Yes & Yes & Yes \\
\hline Observations & 151002 & 176382 & 176382 & 176382 & 176382 & 176382 \\
\hline $\mathrm{R}^{2}$ & 0.89 & 0.89 & 0.89 & 0.89 & 0.89 & 0.89 \\
\hline
\end{tabular}

The sample period of the regressions is from 1996 to 2009, using quarterly Call Report data.

All specifications are panel regressions with fixed effects for bank organizations. All specifications control for the bank-level liquidity and solvency measures in Table 3 (not shown). The reported $\mathrm{R}^{2}$ is the within $\mathrm{R}^{2}$. Columns (1), (3), and (5) control for quarterly time dummies. Columns (2), (4), and (6) exclude quarterly time dummies. In the latter, District time trends are controlled for, as are Crisis1 and Crisis2 dummies. Crisis 1 is a dummy variable equal to 1 from 2007Q3 to 2008Q2, and Crisis 2 is a dummy variable equal to 1 from 2008 Q3 to 2009 Q2.

All regressions also control for the deposit-weighted geographic market deposit concentration (annual from Summary of Deposits).

The standard errors used in calculating significance levels are clustered at the bank organization level.

See Appendix for variable definitions and details about bank panel. ***, **, * indicate 1\%, 5\%, and $10 \%$ significance, respectively. 
Table 7. Average Weekly Funding and Asset Growth (All Domestically Chartered Banks, in \%)

\begin{tabular}{|c|c|c|c|c|c|c|}
\hline \multirow[b]{3}{*}{ Liabilities } & \multicolumn{2}{|c|}{1998 LTCM Crisis } & \multicolumn{4}{|c|}{ 2007-2009 Financial Crisis } \\
\hline & $\begin{array}{l}\text { Previous } 5 \text { years } \\
\text { to crisis }\end{array}$ & Fall 1998 & $\begin{array}{l}\text { Previous } 5 \text { years } \\
\text { to crisis }\end{array}$ & $\begin{array}{l}\text { July } 42007 \text { - } \\
\text { Sept } 102008 \\
\text { (pre-Lehman } \\
\text { failure) }\end{array}$ & $\begin{array}{c}\text { Period } \\
\text { immediately } \\
\text { following } \\
\text { Lehman failure } \\
\text { (last } 2 \text { weeks of } \\
\text { September 2008) }\end{array}$ & $\begin{array}{l}\text { Oct } 82008- \\
\text { July } 12009\end{array}$ \\
\hline & & & & & & \\
\hline Deposits & 0.060 & 0.194 & 0.095 & 0.071 & 0.952 & 0.085 \\
\hline of which, Core deposits & 0.042 & 0.173 & 0.077 & 0.051 & 0.564 & 0.115 \\
\hline Other borrowings & 0.033 & 0.149 & 0.026 & 0.038 & 0.448 & -0.063 \\
\hline $\begin{array}{l}\text { of which, Other borrowings } \\
\text { not from banks in U.S. }\end{array}$ & 0.021 & 0.103 & 0.026 & 0.029 & 0.405 & -0.067 \\
\hline Assets & & & & & & \\
\hline Loans & 0.095 & 0.181 & 0.112 & 0.103 & 0.564 & -0.049 \\
\hline of which, C\&I loans & 0.027 & 0.048 & 0.010 & 0.033 & 0.159 & -0.024 \\
\hline Liquid assets & 0.017 & 0.170 & 0.032 & 0.028 & 0.632 & 0.083 \\
\hline
\end{tabular}

The sample is weekly reporters in the Federal Reserve H8 Release for all domestically chartered banks (exclude the branches and agencies of foreign banks). The weekly growth rates are defined as the weekly change in the variable divided by total assets in the previous week, and then averages are taken within the different time periods shown (1993-1998 and 2002-2009). Note that the H8 Release reports total loans as "loans and leases in bank credit"; core deposits are reported as "other deposits" where total deposits are the sum of "other deposits" and "large-time deposits"; and we take liquid assets as the sum of cash assets, securities, and interbank loans extended. 
Table 8. The Relationship between Market Stress and Growth in Deposits and Loans:

Was it Different in the 2007-2009 Crisis? Revisiting Gatev and Strahan (2006)

\begin{tabular}{|c|c|c|c|c|c|c|c|c|}
\hline & (1) & $(2)$ & (3) & (4) & (5) & (6) & (7) & (8) \\
\hline & \multicolumn{3}{|c|}{$\begin{array}{c}\Delta \text { Deposits/Assets }_{\mathrm{t}-1} \\
\end{array}$} & \multicolumn{3}{|c|}{$\begin{array}{c}\Delta \text { Loans/Assets }_{\mathrm{t}-1} \\
\end{array}$} & \multicolumn{2}{|c|}{ Rates } \\
\hline & $\begin{array}{l}\text { Gatev and } \\
\text { Strahan sample } \\
1991-2000\end{array}$ & $1990-2009$ & $1990-2009$ & $\begin{array}{l}\text { Gatev and } \\
\text { Strahan sample } \\
1991-2000\end{array}$ & 1990-2009 & $1990-2009$ & Large Time & Core \\
\hline Unused commitment ratio $_{\mathrm{t}-1}$ & $\begin{array}{l}-0.021^{* * *} \\
(0.007)\end{array}$ & $\begin{array}{l}0.025^{* * *} \\
(0.003)\end{array}$ & $\begin{array}{l}0.025 * * * \\
(0.003)\end{array}$ & $\begin{array}{l}0.087 * * * \\
(0.010)\end{array}$ & $\begin{array}{l}0.110^{* * *} \\
(0.007)\end{array}$ & $\begin{array}{l}0.113^{* * *} \\
(0.007)\end{array}$ & $\begin{array}{l}-0.434^{* * *} \\
(0.040)\end{array}$ & $\begin{array}{l}-0.323 * * * \\
(0.029)\end{array}$ \\
\hline Unused commitment ratio $_{t-1} \times$ Stress & $\begin{array}{l}0.041 * * * \\
(0.011)\end{array}$ & $\begin{array}{l}0.007 \\
(0.005)\end{array}$ & $\begin{array}{l}0.022 * * * \\
(0.008)\end{array}$ & $\begin{array}{l}0.047 * * * \\
(0.012)\end{array}$ & $\begin{array}{l}0.004 \\
(0.005)\end{array}$ & $\begin{array}{l}0.032 * * * \\
(0.009)\end{array}$ & $\begin{array}{l}0.137^{*} \\
(0.070)\end{array}$ & $\begin{array}{l}-0.147 * * * \\
(0.049)\end{array}$ \\
\hline Unused commitment ratio $_{\mathrm{t}-\mathrm{1}} \times$ Stress $\times$ Crisis 1 & & & $\begin{array}{l}-0.039 * * \\
(0.017)\end{array}$ & & & $\begin{array}{l}-0.020 \\
(0.018)\end{array}$ & $\begin{array}{l}0.250 * * \\
(0.110)\end{array}$ & $\begin{array}{l}0.513^{* * *} \\
(0.082)\end{array}$ \\
\hline Unused commitment ratio $_{\mathrm{t}-\mathrm{1}} \times$ Stress $\times$ Crisis2 & & & $\begin{array}{l}0.018 \\
(0.013)\end{array}$ & & & $\begin{array}{l}-0.023 * \\
0.013\end{array}$ & $\begin{array}{l}0.025 \\
(0.085)\end{array}$ & $\begin{array}{l}0.167 * * * \\
(0.059)\end{array}$ \\
\hline Unused commitment ratio $_{\mathrm{t}-1} \times$ Crisis 1 & & & $\begin{array}{l}0.004 \\
(0.014)\end{array}$ & & & $\begin{array}{l}-0.004 \\
(0.013)\end{array}$ & $\begin{array}{l}-0.049 \\
(0.077)\end{array}$ & $\begin{array}{l}-0.260^{* * *} \\
(0.053)\end{array}$ \\
\hline Unused commitment ratio $\mathrm{t}_{\mathrm{t}-1} \times$ Crisis 2 & & & $\begin{array}{l}-0.011 \\
(0.007)\end{array}$ & & & $\begin{array}{l}-0.021^{* * *} \\
(0.006)\end{array}$ & $\begin{array}{l}0.042 \\
(0.042)\end{array}$ & $\begin{array}{l}-0.037 \\
(0.032)\end{array}$ \\
\hline Capital ratio $\mathrm{t}_{\mathrm{t}-1}$ & $\begin{array}{l}0.144^{* * *} \\
(0.025)\end{array}$ & $\begin{array}{l}0.119 * * * \\
(0.013)\end{array}$ & $\begin{array}{l}0.122^{* * *} \\
(0.013)\end{array}$ & $\begin{array}{l}0.064^{* * *} \\
(0.020)\end{array}$ & $\begin{array}{l}0.059 * * * \\
(0.010)\end{array}$ & $\begin{array}{l}0.061 * * * \\
(0.010)\end{array}$ & $\begin{array}{l}-0.365 * * * \\
(0.085)\end{array}$ & $\begin{array}{l}-0.232^{* * * *} \\
(0.072)\end{array}$ \\
\hline Capital ratio $t_{t-1} \times$ Stress & $\begin{array}{l}0.007 \\
(0.020)\end{array}$ & $\begin{array}{l}0.017 \\
(0.010)\end{array}$ & $\begin{array}{l}-0.001 \\
(0.014)\end{array}$ & $\begin{array}{l}-0.002 \\
(0.024)\end{array}$ & $\begin{array}{l}-0.030^{* * *} \\
(0.012)\end{array}$ & $\begin{array}{l}-0.045^{* * *} \\
(0.016)\end{array}$ & $\begin{array}{l}0.194 \\
(0.162)\end{array}$ & $\begin{array}{l}-0.343^{* *} \\
(0.136)\end{array}$ \\
\hline Capital ratio $_{\mathrm{t}-1} \times$ Stress $\times$ Crisis 1 & & & $\begin{array}{l}0.026 \\
(0.034)\end{array}$ & & & $\begin{array}{l}0.074 \\
(0.048)\end{array}$ & $\begin{array}{l}0.271 \\
(0.298)\end{array}$ & $\begin{array}{l}-0.053 \\
(0.191)\end{array}$ \\
\hline Capital ratio $_{\mathrm{t}-1} \times$ Stress $\times$ Crisis 2 & & & $\begin{array}{l}0.002 \\
(0.023)\end{array}$ & & & $\begin{array}{l}-0.012 \\
(0.027)\end{array}$ & $\begin{array}{l}-0.201 \\
(0.181)\end{array}$ & $\begin{array}{l}0.410^{* * * *} \\
(0.142)\end{array}$ \\
\hline Capital ratio $_{\mathrm{t}-1} \times$ Crisis 1 & & & $\begin{array}{l}0.003 \\
(0.024)\end{array}$ & & & $\begin{array}{l}-0.043 \\
(0.034)\end{array}$ & $\begin{array}{l}-0.175 \\
(0.191)\end{array}$ & $\begin{array}{l}0.106 \\
0.114\end{array}$ \\
\hline Capital ratio $_{\mathrm{t}-1} \times$ Crisis2 & & & $\begin{array}{l}0.046^{* * *} \\
(0.013)\end{array}$ & & & $\begin{array}{l}0.058^{* * *} \\
(0.015)\end{array}$ & $\begin{array}{l}-0.146 \\
(0.098)\end{array}$ & $\begin{array}{l}-0.220^{* * *} \\
(0.064)\end{array}$ \\
\hline Large Bank Indicator (Top 25 by asset size) & $\begin{array}{l}-0.002 \\
(0.004)\end{array}$ & $\begin{array}{l}-0.004 * \\
(0.002)\end{array}$ & $\begin{array}{l}-0.002 \\
(0.002)\end{array}$ & $\begin{array}{l}0.006 \\
(0.004)\end{array}$ & $\begin{array}{l}-0.003 \\
(0.003)\end{array}$ & $\begin{array}{l}-0.003 \\
(0.003)\end{array}$ & $\begin{array}{l}0.013 \\
(0.037)\end{array}$ & $\begin{array}{l}0.014 \\
(0.035)\end{array}$ \\
\hline Large Bank Indicator $\times$ Stress & $\begin{array}{l}0.002 \\
(0.006)\end{array}$ & $\begin{array}{l}0.006^{*} \\
(0.003)\end{array}$ & $\begin{array}{l}-0.001 \\
(0.003)\end{array}$ & $\begin{array}{l}-0.013^{* *} \\
(0.007)\end{array}$ & $\begin{array}{l}0.010 * * * \\
(0.003)\end{array}$ & $\begin{array}{l}0.010 * * \\
(0.004)\end{array}$ & $\begin{array}{l}-0.180^{* *} \\
(0.081)\end{array}$ & $\begin{array}{l}-0.028 \\
(0.033)\end{array}$ \\
\hline Large Bank Indicator $\times$ Stress $\times$ Crisis 1 & & & $\begin{array}{l}0.031^{* * *} \\
(0.012)\end{array}$ & & & $\begin{array}{l}0.017^{*} \\
(0.009)\end{array}$ & $\begin{array}{l}0.250 * * * \\
(0.081)\end{array}$ & $\begin{array}{l}-0.002 \\
(0.037)\end{array}$ \\
\hline Large Bank Indicator $\times$ Stress $\times$ Crisis2 & & & $\begin{array}{l}0.008 \\
(0.012)\end{array}$ & & & $\begin{array}{l}-0.020 * * * \\
(0.007)\end{array}$ & $\begin{array}{l}0.136^{*} \\
(0.075)\end{array}$ & $\begin{array}{l}-0.010 \\
(0.039)\end{array}$ \\
\hline Large Bank Indicator $\times$ Crisis1 & & & $\begin{array}{l}-0.013 \\
(0.009)\end{array}$ & & & $\begin{array}{l}-0.009 \\
(0.007)\end{array}$ & $\begin{array}{l}-0.131^{* * *} \\
(0.048)\end{array}$ & $\begin{array}{l}-0.044^{*} \\
(0.026)\end{array}$ \\
\hline Large Bank Indicator $\times$ Crisis2 & & & $\begin{array}{l}-0.009 \\
(0.006)\end{array}$ & & & $\begin{array}{l}0.014 * * * \\
(0.004)\end{array}$ & $\begin{array}{l}-0.054^{*} \\
(0.033)\end{array}$ & $\begin{array}{l}0.004 \\
(0.016)\end{array}$ \\
\hline Bank Fixed Effects & Yes & Yes & Yes & Yes & Yes & Yes & Yes & Yes \\
\hline Observations & 114323 & 252526 & 252526 & 114323 & 252526 & 252526 & 235491 & 235532 \\
\hline $\mathrm{R}^{2}$ & 0.05 & 0.04 & 0.04 & 0.05 & 0.08 & 0.08 & 0.73 & 0.91 \\
\hline
\end{tabular}

The sample period of the regressions is from 1990 to 2009, except for the Gatev and Strahan sample period (1991-2000). The data are from the quarterly Call Reports.

All specifications are panel regressions with fixed effects for bank organizations and quarterly time dummies. The reported $\mathrm{R}^{2}$ is the within $\mathrm{R}^{2}$.

Crisis 1 is a dummy variable equal to 1 from 2007Q3 to 2008Q2, and Crisis 2 is a dummy equal to 1 from 2008Q3 to 2009Q2. Following Gatev and Strahan, the interaction of

the 3 month Treasury bill rate with unused commitment ratio is also controlled for. The standard errors used in calculating significance levels are clustered at the bank organization level.

See Appendix for variable definitions and details about bank panel. ***, **, * indicate $1 \%, 5 \%$, and $10 \%$ significance, respectively. 
Quarterly growth in deposits Quarterly growth in core deposits

Quarterly growth in insured deposits

Quarterly growth in brokered deposits Transaction account guarantee program deposit share (2008Q4)

Quarterly growth in loans Dependent variables (Bank Rate Monitor 1997-2009)

Deposits: RCFD2200.

Core deposits are the sum of transaction deposits, saving deposits, and time deposits less than $\$ 100,000$ : RCON2215 + RCON6810 + RCON0352 + RCON6648.

Insured deposits are accounts of \$100,000 or less (include retirement accounts of \$250,000 or less after 2006Q2). Note that from 2009Q3, reporting thresholds on non-retirement deposits increased from $\$ 100,000$ to $\$ 250,000$.

Insured deposits: RCON2702 (before 2006Q2); RCONF049 + RCONF045 (from 2006Q2).

Brokered Deposits (received from brokers or dealers): RCON2365.

Non-interest bearing transaction accounts of more than $\$ 250,000$ for banks participating in the FDIC transaction account program (RCONG167). The share at the start of the program (2008Q4) is defined as a share of beginning of period assets. Loans: RCFD1400.

A weekly bank (and thrift) panel data set of current checking and CD rates based on a weekly survey of branches of financial institutions carried out by Bank Rate Monitor (data are proprietary). The panel is unbalanced with 1250 bank-branch cross-sectional observations on average over the period 9/19/1997 - 12/25/2009. This set corresponds to 358 banks and 214 banking organizations on average, respectively (these are a small subset of banks filing Call Reports, which are over 6000 organizations on average). The data are aggregated to top holder by taking the average rate within a banking organization (after cleaning the data for duplicates and missing observations). For branch-level analysis, each branch is matched to the relevant geographic area in the Summary of Deposits.

Interest checking rate CD 12 month rate CD 24 month rate CD 60 month rate

Covariates

Bank failure indicator

Unused commitment ratio

Liquidity ratio (liquid assets to assets, excludes MBS/ABS)

Wholesale funding to asset ratio

Nonperforming loans to loans Capital ratio (book capital to assets) Risk-based capital ratio

Indicator for Large Banks Real Estate Loan Share Residential Mortgages Sold Volatility of daily equity returns (quarterly)

Equity Return (quarterly, market-adjusted) Quasi market capital to asset ratio (end quarter) Reported rate on interest checking account. Reported rate on 12 month CD. Reported rate on 24 month CD. Reported rate on 60 month CD.

Indicator equal to 1 in the quarter corresponding to a bank failure, and 0 otherwise. Failure can be regulatory-assisted (denoted 'formal' fail in Table 2 , near-fail based on market equity data (denoted CRSP fail in Table 2), or both. In total based on Call Report sample, there are 517 formal fails and 91 near-fails (of which 16 result in formal fail later). Specifically, regulatory-assisted failure is if RSSD9061 = 4 or 5 . And cross-checked/merged with FDIC's failed bank list as of 4/16/2010. Regulatory failure is at the bank level. Indicator assigned to top holder if failed bank asset share at time of failure was over $10 \%$ of holding company assets. CRSP near-fails are the period first associated with market equity returns worse than - $90 \%$ over an 18-month period(Acharya et al, 2010). The CRSP data are matched to bank identifiers using the CRSP-FRB link:

http://www.newyorkfed.org/research/banking_research/datasets.html

Unused commitments divided by the sum of unused commitments and loans. Unused commitments are:

RCFD3814 + RCFD3816 + RCFD3817 + RCFD3818 + RCFD6550 + RCFD3411.

Liquid assets are cash, federal funds sold \& reverse repos, and securities excluding MBS/ABS securities: Cash: RCFD0010; Federal funds sold: RCFD1350 (before 2002Q1) and RCONB987 + RCFDB989 (from 2002Q1).

Securities excl. MBS/ABS before 2009Q2: RCFD1754+RCFD1773 - (RCFD8500+RCFD8504+RCFDC026+RCFD8503+RCFD8507+RCFDC027). And from 2009Q2: RCFD1754 + RCFD1773 - (RCFDG300 + RCFDG304 + RCFDG308 + RCFDG312 + RCFDG316 + RCFDG320 + RCFDG324 + RCFDG328 + RCFDC026 + RCFDG336 + RCFDG340 + RCFDG344 + RCFDG303 + RCFDG307 + RCFDG311 + RCFDG315 + RCFDG319 + RCFDG323 + RCFDG327 + RCFDG331 + RCFDC027 + RCFDG339 + RCFDG343 + RCFDG347) Wholesale funds (also known as managed liabilities in the Federal Reserve Bulletin) are the sum of: large-time deposits, deposits booked in foreign offices, subordinated debt and debentures, gross federal funds purchased, repos, and other borrowed money: RCON2604 + RCFN2200 + RCFD3200 + RCFD2800 (RCONB993+RCFDB995 from 2002q1) + RCFD3190.

Loans past due 90 days or more and nonaccruals: RCFD1407 + RCFD1403.

Book capital to asset ratio. Capital: RCFD3210.

Total risk-based capital ratio defined RCFD3792/RCFDA223, where RCFD3792 is total risk-based capital and RCFDA223 are total risk-weighted assets (available only since 1996Q1)

Indicator equal to one for the largest 25 commercial banking organizations by asset size (time-varying).

Loans secured by real estate (RCFD1410) divided by total loans.

Closed-end 1-4 family residential mortgages sold in the quarter, including first and junior liens: RCFDF070 + RCFDF071, divided by assets. The standard deviation of market-adjusted daily returns, where both bank and market returns incorporate dividends. The market return is the SNL bank index. Daily return data are from CRSP.

Return on equity, calculated based on end of quarter and beginning of quarter market prices, and adjusted for market return. Defined as: Market equity/(Book assets - Book equity + Market equity), where market equity equals Shares outstanding*Price end of quarter Book assets and book equity are from Call Reports, where book assets are RCFD2170 and book equity is total equity capital (RCFD3210) minus the book value of preferred stock and related surplus (RCFD3838).

Share of large-time deposits maturing in 1 year Large-time deposits with a remaining maturity or next repricing date of 3 months or less and 3-12 months: RCONA584 + RCONA585, divided by total large-time deposits (RCON2604).

Geographic market deposit concentration (HHI) The branch deposit-weighted geographic market deposit concentration (annual from the FDIC's Summary of Deposits (SOD)).

The geographic market is defined as the MSA (CBSA_METROB) if urban or the county (STCNTYBR) if rural.

Geographic market share of failed deposits

The share of deposits belonging to failed banks and thrifts in a bank's geographic market (branch deposit weighted). See above details on Summary of Deposits and the failed financial institution information above (latter is merged into SOD).

Seniors (65 and over) as a share of population in bank's geographic market (branch deposit-weighted). Data from 2000 census matched to SOD areas) Quarterly percentage change in housing price index (all-transaction) in a bank's geographic market (branch deposit-weighted). Source: FHFA. Change in total private employment, log differences, year-on-year, in a bank's geographic market (branch deposit-weighted). Source: QCEW.

Geographic market senior share Geographic market \% change house prices Geographic market \% change in employment Geographic market \% change in establishments District time trends Shange in total private establishments, log differences, year on year, in a bank's geographic market (branch deposit-weighted). Source: QCEW. Regional time trends based on the Federal Reserve district the main bank in a banking organization is located (RSSD9170).

Aggregate characteristics Commercial paper spread (\%) TED spread (\%) 
Table A1. Summary statistics for regression bank panel 1990Q1-2009Q4

\begin{tabular}{|c|c|c|c|c|c|c|}
\hline & Mean & $\begin{array}{l}\text { Standard } \\
\text { Deviation }\end{array}$ & $\begin{array}{l}\text { 25th } \\
\text { Percentile }\end{array}$ & Median & $\begin{array}{r}\text { 75th } \\
\text { Percentile }\end{array}$ & Observations \\
\hline \multicolumn{7}{|l|}{ Dependent variables (Call Reports) } \\
\hline Interest rate, large time deposits (implicit, in \%) & 1.132 & 0.393 & 0.836 & 1.142 & 1.385 & 238557 \\
\hline Interest rate, core deposits (implicit, in \%) & 0.852 & 0.361 & 0.566 & 0.849 & 1.074 & 238543 \\
\hline Quarterly growth in deposits & 0.011 & 0.031 & -0.006 & 0.008 & 0.028 & 253492 \\
\hline Quarterly growth in core deposits & 0.008 & 0.028 & -0.006 & 0.006 & 0.023 & 253492 \\
\hline Quarterly growth in insured deposits & 0.007 & 0.029 & -0.005 & 0.003 & 0.015 & 244002 \\
\hline Quarterly growth in brokered deposits & 0.001 & 0.008 & 0.000 & 0.000 & 0.000 & 236763 \\
\hline Transaction account guarantee program deposit share (2008Q4) & 0.033 & 0.045 & 0.004 & 0.021 & 0.044 & 21674 \\
\hline Quarterly growth in loans & 0.010 & 0.029 & -0.003 & 0.010 & 0.025 & 253492 \\
\hline \multicolumn{7}{|l|}{ Dependent variables (Bank Rate Monitor 1997-2009) } \\
\hline Interest checking rate (\%) & 0.610 & 0.601 & 0.150 & 0.400 & 1.000 & 107466 \\
\hline CD 12 month rate (\%) & 3.170 & 1.540 & 1.740 & 3.200 & 4.500 & 107298 \\
\hline CD 24 month rate (\%) & 3.448 & 1.412 & 2.230 & 3.444 & 4.640 & 104874 \\
\hline CD 60 month rate (\%) & 4.023 & 1.153 & 3.200 & 4.020 & 4.890 & 97235 \\
\hline \multicolumn{7}{|l|}{ Covariates } \\
\hline Regulatory-assisted failure dummy (formal fail) & 0.0009 & 0.029 & 0.000 & 0.000 & 0.000 & 258108 \\
\hline Market-equity < -90\% failure dummy (CRSP near-fail) & 0.0003 & 0.018 & 0.000 & 0.000 & 0.000 & 258108 \\
\hline All fail dummy (formal and near-fails) & 0.0012 & 0.034 & 0.000 & 0.000 & 0.000 & 258108 \\
\hline Unused commitment ratio & 0.127 & 0.087 & 0.070 & 0.117 & 0.170 & 257078 \\
\hline Liquidity ratio (excludes MBS/ABS) & 0.242 & 0.144 & 0.141 & 0.218 & 0.312 & 215100 \\
\hline Wholesale funding ratio & 0.198 & 0.144 & 0.103 & 0.171 & 0.255 & 258108 \\
\hline Nonperforming loans to loans & 0.012 & 0.020 & 0.002 & 0.007 & 0.014 & 228042 \\
\hline Capital ratio (book capital to assets) & 0.091 & 0.045 & 0.076 & 0.089 & 0.106 & 258108 \\
\hline Risk-based capital ratio & 0.159 & 0.101 & 0.117 & 0.137 & 0.173 & 182675 \\
\hline Indicator for Large Banks & 0.007 & 0.084 & 0.000 & 0.000 & 0.000 & 258108 \\
\hline Real Estate Loan Share & 0.642 & 0.235 & 0.527 & 0.682 & 0.809 & 257015 \\
\hline Residential Mortgages Sold (normalized by assets) & 0.008 & 0.056 & 0.000 & 0.000 & 0.000 & 52964 \\
\hline Volatility of daily equity returns (quarterly) & 0.027 & 0.022 & 0.015 & 0.022 & 0.031 & 28528 \\
\hline Equity Return (quarterly, market-adjusted) & -0.002 & 0.333 & -0.085 & -0.005 & 0.078 & 28528 \\
\hline Quasi market capital to asset ratio (end of quarter) & 0.138 & 0.074 & 0.095 & 0.132 & 0.171 & 28544 \\
\hline Share of large-time deposits maturing in 1 year or less & 0.756 & 0.215 & 0.678 & 0.810 & 0.902 & 175410 \\
\hline Geographic market deposit concentration (HHI, branch deposit-weighted) & 0.175 & 0.108 & 0.102 & 0.148 & 0.213 & 200761 \\
\hline Geographic market share of failed deposits (branch deposit-weighted) & 0.001 & 0.007 & 0.000 & 0.000 & 0.000 & 200761 \\
\hline Geographic market senior share (branch deposit-weighted) & 0.133 & 0.031 & 0.112 & 0.129 & 0.150 & 200761 \\
\hline Geographic market percentage change in house prices (branch deposit-weighted) & 0.009 & 0.017 & 0.003 & 0.010 & 0.017 & 198192 \\
\hline Geographic market percentage change in employment (branch deposit-weighted) & 0.002 & 0.036 & -0.013 & 0.007 & 0.022 & 180754 \\
\hline Geographic market percentage change in establishments (branch deposit-weighte & 0.011 & 0.027 & -0.002 & 0.011 & 0.025 & 180795 \\
\hline \multicolumn{7}{|l|}{ Aggregate characteristics } \\
\hline Commercial paper spread (\%) & 0.37 & 0.23 & 0.20 & 0.37 & 0.47 & 80 \\
\hline TED spread (\%) & 0.58 & 0.37 & 0.32 & 0.52 & 0.68 & 80 \\
\hline
\end{tabular}

\begin{tabular}{|c|c|c|c|c|c|c|c|c|}
\hline \multicolumn{9}{|c|}{ Pairwise Correlation Coeffficients for Key Covariates in Regression Bank Panel 1990Q1-2009Q4 } \\
\hline & & 1 & 2 & 3 & 4 & 5 & 6 & 7 \\
\hline 1 & Unused commitment ratio & 1.000 & & & & & & \\
\hline 2 & Liquidity ratio (excludes MBS/ABS) & -0.059 & 1.000 & & & & & \\
\hline 3 & Wholesale funding ratio & 0.071 & -0.156 & 1.000 & & & & \\
\hline 4 & Nonperforming loans to loans & -0.036 & -0.047 & 0.006 & 1.000 & & & \\
\hline 5 & Capital ratio (book capital to assets) & 0.059 & 0.107 & -0.172 & 0.053 & 1.000 & & \\
\hline 6 & Risk-based capital ratio & -0.159 & 0.402 & -0.138 & -0.029 & 0.701 & 1.000 & \\
\hline 7 & Indicator for Large Banks & 0.225 & -0.044 & 0.091 & 0.009 & 0.003 & -0.030 & 1.000 \\
\hline
\end{tabular}

Source: Call Reports, National Information Center, FDIC, Bank Rate Monitor, Summary of Deposits, CRSP, SNL Financial, HAVER Analytics, Federal Reserve H.15 release, 2000 Census, Federal Housing Finance Agency (FHFA), and Quarterly Census of Employment and Wages.

Note: Summary statistics are calculated over the regression sample (thus exclude mergers, non-U.S. domiciled banking organizations, and those below $\$ 100$ million in total assets). See Appendix for variable definitions. 
Table A2. Aggregate Balance Sheet for Banks During the 2007-2009 Financial Crisis

This table shows the aggregate balance sheet of large banks and small banks, respectively. The second column reports the balance sheet item as a share of total assets in $2007 \mathrm{Q} 2$ (in \%), and the following columns report the evolution over 200703 to 2009Q4. For each balance sheet item, we report two figures (both in \%). The first is the cumulative change of the balance sheet item normalized by 2007Q2 total assets $\left(\mathrm{X}_{\mathrm{t}}-\mathrm{X}_{2007 \mathrm{Q} 2}\right)$ /Total Asset $2007 \mathrm{Q} 2$. The second row (in gray itallics) is the cumulative percent change of the balance sheet item from its level in $2007 \mathrm{Q} 2\left(\ln \mathrm{X}_{\mathrm{t}}-\ln \mathrm{X}_{2007 \mathrm{Q}_{2}}\right)$. The source of the data is bank-level quarterly Call Report data, aggregated to the top holder level, for U.S.-domiciled banks.

\begin{tabular}{|c|c|c|c|c|c|c|c|c|c|c|c|c|c|}
\hline & \multirow{2}{*}{$\begin{array}{c}\text { Average } \\
\text { quarterly } \\
\text { change } \\
\text { 2006Q1- } \\
\text { 2007Q2 } \\
\end{array}$} & \multirow{2}{*}{$\begin{array}{r}\begin{array}{r}\text { Share of } \\
\text { Assets, }\end{array} \\
\text { 2007Q2 } \\
\end{array}$} & \multicolumn{10}{|c|}{ Cumulative Change } & \multirow{2}{*}{$\begin{array}{r}\text { Share of } \\
\text { Assets, } \\
\text { 2009Q4 }\end{array}$} \\
\hline & & & 2007Q3 & 2007Q4 & 2008Q1 & 2008Q2 & 2008Q3 & 2008Q4 & 2009Q1 & 2009Q2 & $2009 \mathrm{Q} 3$ & $2009 \mathrm{Q} 4$ & \\
\hline \multicolumn{14}{|l|}{ Assets } \\
\hline \multirow[t]{2}{*}{ Cash } & 0.1 & 4.3 & -0.1 & 0.3 & 0.5 & 0.6 & 2.7 & 5.7 & 5.3 & 3.9 & 4.6 & 4.6 & 7.6 \\
\hline & 3.6 & & -2.8 & 6.6 & 11.9 & 13.2 & 48.2 & 84.1 & 80.1 & 64.6 & 72.8 & 73.2 & \\
\hline \multirow[t]{2}{*}{ Securities } & 0.3 & 12.3 & 0.1 & 0.0 & 0.5 & 1.3 & 2.3 & 2.3 & 3.8 & 5.3 & 5.8 & 7.1 & 16.5 \\
\hline & 1.8 & & 1.1 & 0.2 & 3.8 & 10.0 & 16.8 & 17.2 & 26.9 & 35.8 & 38.8 & 45.3 & \\
\hline \multirow[t]{2}{*}{ MBS and ABS } & 0.2 & 9.2 & 0.0 & 0.2 & 1.0 & 1.6 & 2.6 & 2.0 & 2.4 & 3.5 & 3.4 & 3.9 & 11.2 \\
\hline & 2.4 & & 0.1 & 2.5 & 10.2 & 16.1 & 24.8 & 19.8 & 23.3 & 32.1 & 31.2 & 35.1 & \\
\hline \multirow[t]{2}{*}{ Fed Funds and Repos } & 0.2 & 5.4 & 0.4 & 1.2 & 1.9 & 1.8 & 2.1 & 2.3 & 1.3 & 0.6 & -0.1 & -0.9 & 3.8 \\
\hline & 3.7 & & 7.6 & 20.9 & 30.1 & 28.8 & 32.5 & 36.4 & 21.3 & 10.4 & -1.1 & -19.0 & \\
\hline \multirow[t]{2}{*}{ Trading Assets } & 0.5 & 11.0 & 1.0 & 1.8 & 3.1 & 1.9 & 2.0 & 2.4 & 0.3 & -0.5 & 0.5 & 0.0 & 9.3 \\
\hline & 5.2 & & 8.8 & 15.0 & 25.2 & 16.2 & 17.0 & 20.0 & 2.8 & -4.4 & 4.7 & -0.1 & \\
\hline \multirow[t]{2}{*}{ Total Loans } & 1.5 & 49.1 & 2.2 & 5.1 & 5.6 & 5.2 & 8.0 & 6.8 & 5.6 & 5.7 & 4.1 & 3.8 & 45.1 \\
\hline & 3.0 & & 4.4 & 9.8 & 10.8 & 10.1 & 15.0 & 12.9 & 10.9 & 10.9 & 8.0 & 7.5 & \\
\hline \multirow[t]{2}{*}{ Real estate } & 0.9 & 25.0 & 0.4 & 1.8 & 1.8 & 1.2 & 3.4 & 3.2 & 3.0 & 3.7 & 2.9 & 3.4 & 24.3 \\
\hline & 3.7 & & 1.4 & 6.9 & 6.8 & 4.8 & 12.7 & 11.9 & 11.4 & 13.6 & 11.1 & 12.9 & \\
\hline \multirow[t]{2}{*}{ C\&I } & 0.4 & 10.3 & 0.9 & 1.6 & 2.0 & 2.0 & 2.2 & 2.0 & 1.6 & 1.0 & 0.1 & -0.8 & 8.1 \\
\hline & 4.3 & & 8.6 & 14.5 & 18.1 & 17.9 & 19.4 & 18.1 & 14.9 & 8.9 & 0.8 & -7.6 & \\
\hline \multirow[t]{2}{*}{ Other loans } & 0.1 & 13.8 & 0.9 & 1.7 & 1.8 & 2.0 & 2.4 & 1.6 & 1.0 & 1.1 & 1.1 & 1.2 & 12.7 \\
\hline & 0.9 & & 6.6 & 11.5 & 12.3 & 13.4 & 15.9 & 10.8 & 6.8 & 7.5 & 7.6 & 8.1 & \\
\hline Total Assets & 3.2 & 100.0 & 4.8 & 10.8 & 14.7 & 13.5 & 19.6 & 20.8 & 17.0 & 16.1 & 16.6 & 16.0 & \\
\hline \multicolumn{14}{|l|}{ Liabilities } \\
\hline \multirow{4}{*}{$\begin{array}{l}\text { Deposits } \\
\text { of which: } \\
\text { Insured deposits }^{(a)}\end{array}$} & 1.7 & 56.5 & 2.5 & 6.6 & 8.2 & 7.8 & 11.6 & 14.4 & 12.9 & 14.2 & 15.8 & 17.3 & 62.9 \\
\hline & 3.0 & & 4.3 & 11.0 & 13.6 & 12.9 & 18.7 & 22.7 & 20.6 & 22.4 & 24.6 & 26.7 & \\
\hline & 0.4 & 17.2 & 0.1 & 0.8 & 1.7 & 1.7 & 3.9 & 4.6 & 5.6 & 5.4 & 11.2 & 12.0 & 24.9 \\
\hline & 2.1 & & 0.7 & 4.7 & 9.5 & 9.3 & 20.4 & 23.8 & 28.2 & 27.4 & 50.0 & 52.9 & \\
\hline \multirow[t]{2}{*}{ Core deposits $^{(b)}$} & 0.6 & 32.3 & 0.2 & 2.4 & 3.8 & 3.4 & 6.3 & 9.7 & 10.8 & 11.8 & 12.4 & 14.7 & 40.0 \\
\hline & 1.6 & & 0.6 & 7.1 & 11.1 & 9.9 & 17.8 & 26.3 & 28.9 & 31.1 & 32.6 & 37.4 & \\
\hline \multirow[t]{2}{*}{ Uninsured deposits $^{(a)}$} & 1.3 & 39.3 & 2.4 & 5.7 & 6.5 & 6.1 & 7.7 & 9.7 & 7.3 & 8.8 & 4.6 & 5.3 & 38.0 \\
\hline & 3.4 & & 5.8 & 13.6 & 15.3 & 14.5 & 18.0 & 22.1 & 17.0 & 20.2 & 11.1 & 12.6 & \\
\hline \multirow[t]{2}{*}{ Large time deposits } & 0.1 & 5.9 & 0.6 & 1.5 & 1.8 & 1.3 & 2.8 & 2.0 & 1.2 & 0.8 & 0.2 & -0.2 & 4.9 \\
\hline & 1.1 & & 9.7 & 23.2 & 26.9 & 20.5 & 39.2 & 29.6 & 18.7 & 12.1 & 4.1 & -3.5 & \\
\hline Fed Funds and Repos & 0.3 & 7.3 & -0.2 & -0.1 & 0.6 & 0.8 & 1.4 & 0.6 & 0.5 & 0.3 & -0.1 & -2.1 & 4.5 \\
\hline & 3.4 & & -3.3 & -1.0 & 8.4 & 10.0 & 17.4 & 8.0 & 6.4 & 4.5 & -2.0 & -33.2 & \\
\hline Trading Liabilities & 0.1 & 4.5 & 0.5 & 0.6 & 1.2 & 0.7 & 0.5 & 1.8 & 0.5 & -0.6 & -0.1 & -0.6 & 3.3 \\
\hline & 1.7 & & 10.3 & 11.8 & 24.0 & 15.1 & 11.3 & 34.5 & 9.9 & -14.3 & -3.3 & -15.5 & \\
\hline Other borrowing & 0.4 & 9.0 & 1.4 & 1.5 & 1.8 & 1.8 & 3.8 & 3.1 & 2.2 & 0.6 & -0.9 & -0.4 & 7.4 \\
\hline & 4.7 & & 14.3 & 15.3 & 17.9 & 18.0 & 34.7 & 29.6 & 21.5 & 5.9 & -10.3 & -4.1 & \\
\hline of which: FHLB Advances & 0.2 & 2.5 & 0.7 & 0.8 & 0.9 & 0.9 & 2.3 & 1.5 & 1.0 & 0.9 & 0.5 & 0.5 & 2.6 \\
\hline & 7.5 & & 24.9 & 27.3 & 31.3 & 29.8 & 64.3 & 47.2 & 32.0 & 30.9 & 16.4 & 19.1 & \\
\hline of which: Other (incl. Federal Reserve) & 0.2 & 6.5 & 0.7 & 0.7 & 0.8 & 0.9 & 1.5 & 1.6 & 1.2 & -0.4 & -1.3 & -0.9 & 4.8 \\
\hline & 3.7 & & 9.9 & 10.1 & 12.1 & 13.0 & 20.3 & 21.8 & 17.1 & -5.8 & -23.0 & -14.8 & \\
\hline Subordinated Debt & 0.1 & 1.8 & 0.1 & 0.2 & 0.2 & 0.2 & 0.2 & 0.3 & 0.1 & 0.1 & 0.0 & -0.1 & 1.5 \\
\hline & 5.4 & & 3.8 & 9.0 & 8.8 & 8.4 & 8.3 & 13.9 & 6.4 & 4.6 & 0.4 & -3.4 & \\
\hline Capital & 0.3 & 10.6 & 0.6 & 1.3 & 1.5 & 1.5 & 1.7 & 1.6 & 2.5 & 3.0 & 3.5 & 3.9 & 12.4 \\
\hline & 3.0 & & 5.5 & 11.3 & 13.0 & 13.3 & 14.5 & 14.4 & 21.2 & 24.8 & 28.1 & 31.2 & \\
\hline
\end{tabular}

Note:

(a) There is a break in the insured deposit series in 2009Q3 when banks were asked to report accounts under $\$ 250,000$ (the previous account limit reported was under $\$ 100,000$ ). (b) Core deposits are defined as the sum of transaction deposits, savings deposits (including MMDAs), and time deposits of less than \$100,000.

Both core and large time deposits are components of domestic deposits. The remaining component of total deposits are foreign deposits. 
Panel B. Small Banks

\begin{tabular}{|c|c|c|c|c|c|c|c|c|c|c|c|c|c|}
\hline & \multirow{2}{*}{$\begin{array}{c}\text { Average } \\
\text { quarterly } \\
\text { change }\end{array}$} & \multirow{2}{*}{$\begin{array}{l}\text { Share of } \\
\text { Assets, } \\
\text { 2007Q2 } \\
\end{array}$} & \multicolumn{10}{|c|}{ Cumulative Change } & \multirow{2}{*}{$\begin{array}{r}\text { Share of } \\
\text { Assets, } \\
\text { 2009Q4 } \\
\end{array}$} \\
\hline & & & 2007Q3 & 2007Q4 & 2008Q1 & 2008Q2 & 2008Q3 & 2008Q4 & 2009Q1 & 2009Q2 & 2009Q3 & 2009Q4 & \\
\hline \multicolumn{14}{|l|}{ Assets } \\
\hline \multirow[t]{2}{*}{ Cash } & -0.1 & 3.4 & 0.0 & 0.0 & 0.1 & 0.3 & 1.2 & 6.6 & 5.5 & 4.3 & 6.7 & 7.9 & 11.1 \\
\hline & -2.1 & & 1.4 & 0.2 & 3.4 & 8.4 & 29.9 & 108.3 & 96.1 & 82.1 & 109.2 & 120.6 & \\
\hline \multirow[t]{2}{*}{ Securities } & -0.1 & 16.1 & 0.0 & -0.2 & -1.1 & -1.2 & -1.5 & -0.9 & -0.6 & -0.9 & -0.4 & -0.4 & 15.4 \\
\hline & -0.4 & & -0.1 & -1.4 & -6.9 & -8.0 & -9.9 & -5.9 & -4.0 & -5.4 & -2.2 & -2.8 & \\
\hline \multirow[t]{2}{*}{ MBS and ABS } & -0.1 & 6.1 & -0.3 & -0.4 & -0.5 & -0.4 & -0.4 & -0.2 & -0.1 & 0.0 & 0.2 & 0.3 & 6.3 \\
\hline & -1.3 & & -5.8 & -6.9 & -8.4 & -7.1 & -6.2 & -3.2 & -1.0 & 0.5 & 3.8 & 4.8 & \\
\hline \multirow[t]{2}{*}{ Fed Funds and Repos } & 0.3 & 6.6 & 0.0 & 0.0 & -0.4 & -1.3 & -4.0 & -5.3 & -5.3 & -5.5 & -5.7 & -5.7 & 0.8 \\
\hline & 5.3 & & 0.3 & 0.2 & -6.7 & -22.4 & -93.5 & -167.9 & -164.3 & -182.7 & -203.7 & -206.4 & \\
\hline \multirow[t]{2}{*}{ Trading Assets } & 0.3 & 5.5 & -0.1 & 0.0 & 0.9 & 0.2 & -0.1 & 0.3 & -0.2 & -1.2 & -1.4 & -2.2 & 3.2 \\
\hline & 5.7 & & -1.3 & -0.8 & 15.4 & 4.1 & -2.4 & 5.9 & -4.6 & -24.9 & -30.0 & -50.6 & \\
\hline \multirow[t]{2}{*}{ Total Loans } & 0.8 & 51.7 & 1.6 & 2.4 & 2.6 & 3.3 & 4.7 & 5.1 & 4.0 & 3.1 & 1.5 & 0.8 & 51.3 \\
\hline & 1.5 & & 3.0 & 4.5 & 4.9 & 6.3 & 8.7 & 9.4 & 7.5 & 5.8 & 2.8 & 1.4 & \\
\hline \multirow[t]{2}{*}{ Real estate } & 0.4 & 30.2 & 0.4 & 0.6 & 0.7 & 1.3 & 1.8 & 1.8 & 2.2 & 2.0 & 1.3 & 1.0 & 30.6 \\
\hline & 1.2 & & 1.3 & 1.9 & 2.3 & 4.3 & 5.8 & 5.8 & 7.1 & 6.5 & 4.1 & 3.3 & \\
\hline \multirow[t]{2}{*}{ C\&I } & 0.3 & 11.9 & 0.8 & 1.3 & 1.4 & 1.7 & 2.3 & 2.7 & 1.9 & 1.3 & 0.7 & 0.6 & 12.2 \\
\hline & 2.2 & & 6.7 & 10.4 & 10.9 & 13.5 & 17.8 & 20.7 & 14.8 & 10.3 & 5.5 & 4.8 & \\
\hline \multirow[t]{2}{*}{ Other loans } & 0.2 & 9.6 & 0.4 & 0.5 & 0.5 & 0.3 & 0.6 & 0.6 & -0.1 & -0.2 & -0.4 & -0.8 & 8.6 \\
\hline & 1.7 & & 3.9 & 5.2 & 5.0 & 3.1 & 5.7 & 6.0 & -0.6 & -2.2 & -4.8 & -9.2 & \\
\hline Total Assets & 2.1 & 100.0 & 1.5 & 3.0 & 4.4 & 4.2 & 4.7 & 5.2 & 3.5 & 2.3 & 2.8 & 2.0 & \\
\hline \multicolumn{14}{|l|}{ Liabilities } \\
\hline \multirow{2}{*}{ Deposits } & 0.3 & 48.7 & -0.6 & -1.0 & -1.0 & -0.9 & -0.3 & 0.7 & 1.0 & 1.1 & 1.2 & 2.0 & 49.7 \\
\hline & 0.6 & & -1.2 & -2.1 & -2.0 & -1.9 & -0.6 & 1.5 & 2.0 & 2.2 & 2.4 & 4.0 & \\
\hline \multirow[t]{2}{*}{ Insured deposits ${ }^{(a)}$} & 0.3 & 24.6 & 0.0 & 0.0 & 0.7 & 1.0 & 2.3 & 3.0 & 2.0 & 1.9 & 10.1 & 10.0 & 33.9 \\
\hline & 1.0 & & 0.1 & 0.0 & 3.0 & 4.0 & 9.0 & 11.3 & 7.8 & 7.4 & 34.3 & 34.3 & \\
\hline \multirow[t]{2}{*}{ Core deposits $^{(b)}$} & 0.2 & 39.2 & -0.4 & -0.7 & -0.7 & -0.5 & 0.0 & 0.9 & 0.5 & 0.7 & 1.0 & 1.9 & 40.2 \\
\hline & 0.5 & & -1.0 & -1.7 & -1.9 & -1.4 & 0.1 & 2.1 & 1.3 & 1.8 & 2.5 & 4.8 & \\
\hline \multirow[t]{2}{*}{ Uninsured deposits ${ }^{(a)}$} & 0.0 & 24.1 & -0.6 & -1.0 & -2.0 & -1.9 & -2.6 & -2.2 & -1.0 & -0.8 & -8.8 & -8.0 & 15.7 \\
\hline & 0.1 & & -2.6 & -4.3 & -8.5 & -8.3 & -11.4 & -9.7 & -4.4 & -3.4 & -45.7 & -40.6 & \\
\hline Large time deposits & 1.0 & 24.4 & 1.7 & 2.4 & 3.4 & 3.8 & 2.7 & -0.2 & -0.1 & 1.3 & 2.4 & 3.6 & 27.4 \\
\hline & 4.1 & & 6.8 & 9.6 & 13.0 & 14.4 & 10.7 & -0.7 & -0.3 & 5.2 & 9.4 & 13.7 & \\
\hline Fed Funds and Repos & 0.3 & 8.8 & -0.5 & -0.7 & -0.4 & -1.0 & -2.0 & -3.8 & -3.4 & -2.8 & -2.8 & -3.2 & 5.5 \\
\hline & 3.1 & & -6.0 & -7.8 & -4.2 & -12.4 & -25.6 & -56.4 & -48.8 & -38.7 & -38.5 & -45.5 & \\
\hline Trading Liabilities & 0.1 & 2.3 & -0.1 & 0.0 & 0.3 & 0.0 & -0.2 & 0.9 & 0.5 & -0.2 & 0.1 & -0.4 & 1.9 \\
\hline & 4.5 & & -5.0 & 0.2 & 13.2 & -1.8 & -7.4 & 34.1 & 18.2 & -8.8 & 2.2 & -19.3 & \\
\hline Other borrowing & 0.2 & 9.2 & 0.3 & 1.6 & 2.5 & 3.5 & 3.9 & 6.1 & 5.6 & 4.1 & 2.7 & 0.9 & 9.9 \\
\hline & 2.2 & & 2.9 & 15.7 & 23.7 & 32.3 & 35.7 & 50.9 & 47.6 & 36.7 & 25.3 & 8.9 & \\
\hline of which: FHLB Advances & 0.0 & 3.3 & 0.4 & 0.8 & 1.0 & 1.3 & 1.6 & 1.2 & 0.7 & 0.5 & 0.3 & 0.2 & 3.4 \\
\hline & 0.4 & & 11.6 & 21.2 & 26.1 & 32.7 & 39.0 & 31.6 & 20.1 & 15.2 & 9.4 & 5.8 & \\
\hline of which: Other (incl. Federal Reserve) & 0.0 & 1.1 & 0.1 & 0.1 & 0.1 & 0.3 & 0.2 & 0.3 & 0.4 & 0.3 & 0.1 & 0.1 & 1.1 \\
\hline & 1.2 & & 4.8 & 12.8 & 9.6 & 22.6 & 16.0 & 26.0 & 28.8 & 21.0 & 12.5 & 8.6 & \\
\hline Subordinated Debt & 0.0 & 0.3 & 0.0 & 0.0 & 0.0 & 0.0 & 0.0 & 0.0 & 0.0 & 0.0 & -0.1 & 0.0 & 0.2 \\
\hline & -2.5 & & 1.4 & -1.1 & -0.6 & -0.4 & 2.2 & -2.6 & -17.3 & -18.4 & -25.0 & -13.0 & \\
\hline Capital & 0.1 & 6.9 & 0.1 & 0.0 & 0.0 & -0.1 & 0.0 & -0.1 & -0.1 & -0.1 & 0.1 & 0.0 & 6.8 \\
\hline & 1.1 & & 1.0 & -0.4 & 0.2 & -0.9 & -0.5 & -1.5 & -2.0 & -1.1 & 1.0 & 0.1 & \\
\hline
\end{tabular}

Note:
(a) There is a break in the insured deposit series in 2009Q3 when banks were asked to report accounts under $\$ 250,000$ (the previous account limit reported was under $\$ 100,000$ ). (b) Core deposits are defined as the sum of transaction deposits, savings deposits (including MMDAs), and time deposits of less than $\$ 100,000$.

(b) Core deposits are defined as the sum of transaction deposits, savings deposits (including MMDAs), and time deposits of less than $\$ 100,00$ and large time deposits are components of domestic deposits. The remaining component of total deposits are foreign deposits.
Both core 
Table A3. Industry Equilibrium: The Interdependence between Banks' Deposit Rates

Branch-Level Analysis using the BRM data set (24 month CD)

Stress Proxy = Dummy from Bear Stearns failure to Emergency Economic Stabilization Act (March 14, 2008 - October 3, 2008)

(1)

$0.727^{*}$

(0.436)

market (Fail-share)

(2)

(3)

(4)

(5)

(6)

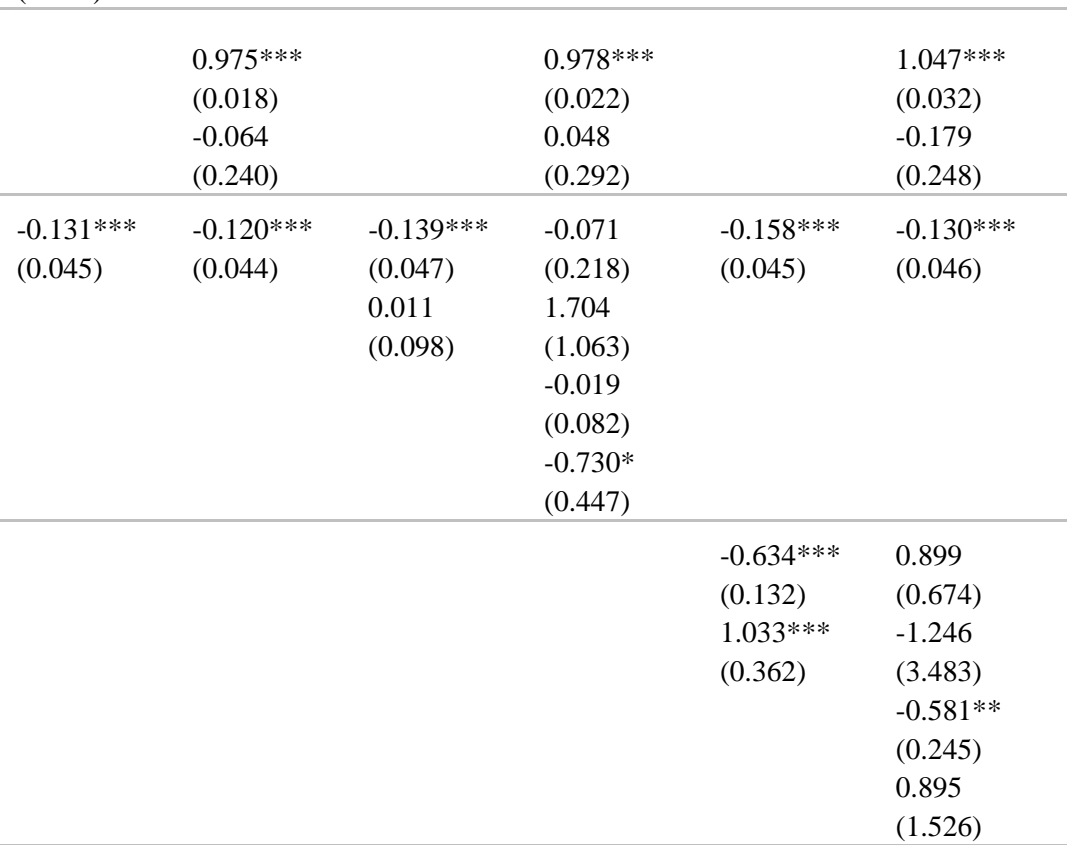

\section{Local conditions controls}

Percentage change in house prices in a bank branch's geographic market $t_{t}$

Percentage change in employment in a bank branch's geographic market ${ }_{\mathrm{t}}$

Percentage change in establishments in a bank branch's

$-0.205$

$(0.331)$

$-0.212$

$-0.140$

(0.353)

$-0.282$

(0.355)

$-0.139$

(0.355)

$-0.263$

(0.361)

$-0.117$

(0.219)

$-0.576$

$-0.215$

$-0.578$

$-0.215$

$(0.359)$

0.370 *

(0.420)

(0.220)

(0.419)

(0.233)

$-0.617$

$(0.215)$

(0.328)

0.381 *

0.119

0.314

(0.426)

geographic market $_{\mathrm{t}}$

Yes

470986

Yes

Observations

0.92

470986

Yes

0.91

470986

(0.331)

(0.210)

(0.320)

The sample period of the regressions is from 1997 to 2009, using weekly Bank Rate Monitor branch-level data for the dependent variables. All specifications include fixed effects for bank organizations, and control for the bank-level liquidity and solvency measures (not shown). Columns (1), (3), and (5) control for weekly time dummies. Columns (2), (4), and (6) exclude weekly time dummies. In the latter regressions, the Stress period dummy is controlled for. The standard errors used in calculating significance levels are clustered at the bank organization level. See Appendix for variable definitions and details about bank panel. ***, **, * indicate 1\%, 5\%, and 10\% significance, respectively. 
Table A4. Predictors of Bank Failure in the Crisis: Bank Riskiness and Interest Rate Contagion (Regressions control for local economic conditions and deposit market concentration)

\begin{tabular}{|c|c|c|c|c|c|c|}
\hline & (1) & (2) & (3) & (4) & (5) & (6) \\
\hline & All Fail & All Fail & Formal Fail & All Fail & All Fail & All Fail \\
\hline & $\begin{array}{l}\text { Linear probability } \\
\text { model }\end{array}$ & $\begin{array}{l}\text { Linear probability } \\
\text { model (IV) }\end{array}$ & $\begin{array}{l}\text { Linear probability } \\
\text { model (IV) }\end{array}$ & $\begin{array}{l}\text { Linear probability } \\
\text { model (IV) }\end{array}$ & $\begin{array}{l}\text { Proportional } \\
\text { Hazards Cox } \\
\text { model }\end{array}$ & $\begin{array}{l}\text { Proportional } \\
\text { Hazards Cox } \\
\text { model }\end{array}$ \\
\hline & $\begin{array}{l}\text { Cross-sectional } \\
\text { (failure over post- } \\
\text { 2007Q3 period) }\end{array}$ & $\begin{array}{l}\text { Cross-sectional } \\
\text { (failure over post- } \\
\text { 2007Q3 period) }\end{array}$ & $\begin{array}{l}\text { Cross-sectional } \\
\text { (failure over post- } \\
\text { 2007Q3 period) }\end{array}$ & $\begin{array}{l}\text { Cross-sectional } \\
\text { (failure over post- } \\
\text { 2008Q3 period) }\end{array}$ & $\begin{array}{l}\text { Pooled (failure is } \\
\text { time-specific } \\
\text { within post- } \\
\text { 2007Q3 period) }\end{array}$ & $\begin{array}{l}\text { Pooled (failure is } \\
\text { time-specific } \\
\text { within post- } \\
\text { 2007Q3 period) }\end{array}$ \\
\hline \multicolumn{7}{|l|}{ Interest rate contagion } \\
\hline $\begin{array}{l}\text { Average large time deposit rate of other } \\
\text { banks in local market(2007Q3-2009Q4) }\end{array}$ & $\begin{array}{l}0.213^{* * *} \\
(0.057)\end{array}$ & & & & & \\
\hline $\begin{array}{l}\text { Average core deposit rate of other banks in } \\
\text { local market(2007Q3-2009Q4) }\end{array}$ & $\begin{array}{l}0.059 \\
(0.059)\end{array}$ & & & & & \\
\hline $\begin{array}{l}\text { Large-time deposit rate (instrumented) } \\
\text { (2007Q3-2009Q4) }\end{array}$ & & $\begin{array}{l}0.298 * * * \\
(0.052)\end{array}$ & $\begin{array}{l}0.340 * * * \\
(0.049)\end{array}$ & & $\begin{array}{l}3.731 * * * \\
(0.773)\end{array}$ & $\begin{array}{l}3.580 * * * \\
(0.763)\end{array}$ \\
\hline $\begin{array}{l}\text { Large-time deposit rate (instrumented) } \\
\text { (2007Q3-2008Q2) }\end{array}$ & & & & $\begin{array}{l}0.388 * * * \\
(0.130)\end{array}$ & & \\
\hline \multicolumn{7}{|l|}{ Bank risk measures and controls } \\
\hline Unused commitment ratio (pre-crisis) & $\begin{array}{l}0.208 * * * \\
(0.045)\end{array}$ & $\begin{array}{l}0.244 * * * \\
(0.047)\end{array}$ & $\begin{array}{l}0.140 * * * \\
(0.040)\end{array}$ & $\begin{array}{l}0.224^{* * *} \\
(0.050)\end{array}$ & $\begin{array}{l}6.947 * * * \\
(0.913)\end{array}$ & $\begin{array}{l}6.386 * * * \\
(0.885)\end{array}$ \\
\hline Liquidity ratio (pre-crisis) & $\begin{array}{l}-0.111^{* * *} \\
(0.026)\end{array}$ & $\begin{array}{l}-0.063^{* *} \\
(0.028)\end{array}$ & $\begin{array}{l}-0.003 \\
(0.025)\end{array}$ & $\begin{array}{l}-0.062 * \\
(0.034)\end{array}$ & $\begin{array}{l}-5.624 * * * \\
(1.460)\end{array}$ & $\begin{array}{l}-6.016^{* * * *} \\
(1.489)\end{array}$ \\
\hline Wholesale funding (pre-crisis) & $\begin{array}{l}0.118^{* * * *} \\
(0.035)\end{array}$ & $\begin{array}{l}0.089 * * \\
(0.036)\end{array}$ & $\begin{array}{l}0.068 * * \\
(0.033)\end{array}$ & $\begin{array}{l}0.069 * \\
(0.042)\end{array}$ & $\begin{array}{l}2.397^{* * *} \\
(0.698)\end{array}$ & $\begin{array}{l}2.329 * * * \\
(0.658)\end{array}$ \\
\hline NPL to Loans (pre-crisis) & $\begin{array}{l}1.991 * * * \\
(0.401)\end{array}$ & $\begin{array}{l}1.912 * * * \\
(0.394)\end{array}$ & $\begin{array}{l}1.533 * * * \\
(0.359)\end{array}$ & $\begin{array}{l}2.138 * * * \\
(0.402)\end{array}$ & $\begin{array}{l}24.169 * * * \\
(3.477)\end{array}$ & $\begin{array}{l}17.980 * * * \\
(3.790)\end{array}$ \\
\hline Risk-based capital ratio (pre-crisis) & $\begin{array}{l}-0.069 * * * \\
(0.021)\end{array}$ & $\begin{array}{l}-0.085^{* * * *} \\
(0.022)\end{array}$ & $\begin{array}{l}-0.070 * * * \\
(0.020)\end{array}$ & $\begin{array}{l}-0.087 * * * \\
(0.025)\end{array}$ & $\begin{array}{l}-17.134 * * * \\
(4.859)\end{array}$ & $\begin{array}{l}-16.185^{* * *} \\
(4.842)\end{array}$ \\
\hline Large Bank Indicator (pre-crisis) & $\begin{array}{l}0.163 * \\
(0.091)\end{array}$ & $\begin{array}{l}0.190 * * \\
(0.090)\end{array}$ & $\begin{array}{l}-0.055^{* * *} \\
(0.016)\end{array}$ & $\begin{array}{l}0.210^{* *} \\
(0.091)\end{array}$ & $\begin{array}{l}0.584 \\
(0.440)\end{array}$ & $\begin{array}{l}0.620 \\
(0.450)\end{array}$ \\
\hline Large-time deposit rate (pre-crisis) & $\begin{array}{l}0.006^{*} \\
(0.003)\end{array}$ & $\begin{array}{l}-0.003 \\
(0.003)\end{array}$ & $\begin{array}{l}-0.006 \\
(0.004)\end{array}$ & $\begin{array}{l}-0.007 \\
(0.008)\end{array}$ & $\begin{array}{l}0.080 \\
(0.242)\end{array}$ & $\begin{array}{l}0.087 \\
(0.240)\end{array}$ \\
\hline Deposit growth & & & & & & $\begin{array}{l}-14.621^{* * * *} \\
(2.372)\end{array}$ \\
\hline Deposit growth t-1 $_{1}$ & & & & & & $\begin{array}{l}-3.500 * * \\
(1.675)\end{array}$ \\
\hline Deposit growth t-2 $_{\text {. }}$ & & & & & & $\begin{array}{l}-0.237 \\
(1.071)\end{array}$ \\
\hline Observations & 4217 & 4217 & 4217 & 4046 & 36403 & 36386 \\
\hline $\mathrm{R}^{2}$ & 0.10 & 0.09 & 0.06 & 0.04 & - & - \\
\hline Likelihood ratio test $\chi^{2}$ (model degrees of freedom) & & & & & 446.7 & 481.4 \\
\hline
\end{tabular}

The sample period of the regressions is from 2007Q3 to 2009Q4, using quarterly Call Report data. The regressions are cross-sectional in columns (1) to (4), where the dependent variable is failure occurring at any point during the crisis (post-2007Q3 period). The regressions are pooled cross-sectional and time-series for the hazard analysis in columns (5) and (6), where failure is bank-time specific and the model allows for time-varying covariates.

Columns (5) and (6) report the parameter estimates $\beta$ from the Cox proportional hazards analysis.

Failure covers both regulatory-assisted failures and near-fails, as measured by large negative returns on the market value of equity (specifically, the first date when the 18-month return was worse than -90\% using daily CRSP data following Acharya, Pedersen, Philippon, and Richardson, 2010), with the exception of column (3) which is for regulatory failure only.

All regressions also control for the deposit concentration and fractions of seniors in the local market, as well as for local economic conditions (percentage change in house prices, employment and establishments - both pre-crisis (2006Q1-2007Q2 average) and during the crisis).

The standard errors used in calculating significance levels are robust and are clustered at the bank organization level in columns (5) and (6).

See Appendix for variable definitions and details about bank panel. ***, **, * indicate 1\%, 5\%, and $10 \%$ significance, respectively. 
Table A5. The Relationship between Offered Deposit Rates and Bank Risk Characteristics: An Alternative Data Set

Weekly, Bank Rate Monitor (BRM): September 1997 - December 2009)

Banks covered by the BRM survey are a small share of all banks filing Call Reports

\begin{tabular}{|c|c|c|c|c|c|c|c|c|}
\hline & \multicolumn{4}{|c|}{$\begin{array}{c}\text { Stress Proxy = Dummy from Bear Stearns failure to Emergency Economic } \\
\text { Stabilization Act (March 14, } 2008 \text { - October 3, 2008) }\end{array}$} & \multicolumn{4}{|c|}{ Stress Proxy = Commercial Paper Spread (weekly) } \\
\hline & \multicolumn{2}{|c|}{ High NPL } & \multicolumn{2}{|c|}{ Low NPL } & \multicolumn{2}{|c|}{ High NPL } & \multicolumn{2}{|c|}{ Low NPL } \\
\hline & $\begin{array}{l}1) \\
24 \text { month } \mathrm{CD} \\
\end{array}$ & $\begin{array}{l}(2) \\
60 \text { month CD }\end{array}$ & $\begin{array}{l}3) \\
24 \text { month CD }\end{array}$ & $\begin{array}{l}4) \\
60 \text { month CD }\end{array}$ & $\begin{array}{l}5) \\
24 \text { month } \mathrm{CD} \\
\end{array}$ & $\begin{array}{l}6) \\
60 \text { month CD }\end{array}$ & $\begin{array}{l}7) \\
24 \text { month CD }\end{array}$ & $\begin{array}{l}8) \\
60 \text { month } \mathrm{CD} \\
\end{array}$ \\
\hline \multicolumn{9}{|l|}{ Liquidity measures } \\
\hline Unused commitment ratio $\mathrm{t}_{-1}$ & $\begin{array}{l}-0.067 \\
(0.337)\end{array}$ & $\begin{array}{l}0.107 \\
(0.421)\end{array}$ & $\begin{array}{l}0.202 \\
(0.403)\end{array}$ & $\begin{array}{l}-0.161 \\
(0.415)\end{array}$ & $\begin{array}{l}-0.230 \\
(0.352)\end{array}$ & $\begin{array}{l}-0.042 \\
(0.442)\end{array}$ & $\begin{array}{l}0.059 \\
(0.404)\end{array}$ & $\begin{array}{l}-0.094 \\
(0.386)\end{array}$ \\
\hline Unused commitment ratio $\mathrm{t}_{\mathrm{t}-1} \times$ Stress Proxy & $\begin{array}{l}0.891^{*} \\
(0.472)\end{array}$ & $\begin{array}{l}1.761^{* *} \\
(0.690)\end{array}$ & $\begin{array}{l}-0.436 \\
(0.621)\end{array}$ & $\begin{array}{l}1.028 \\
(0.715)\end{array}$ & $\begin{array}{l}0.617^{* *} \\
(0.299)\end{array}$ & $\begin{array}{l}0.540 \\
(0.340)\end{array}$ & $\begin{array}{l}0.368 \\
(0.298)\end{array}$ & $\begin{array}{l}-0.117 \\
(0.452)\end{array}$ \\
\hline Liquidity ratio ${ }_{t-1}$ & $\begin{array}{l}0.396 \\
(0.265)\end{array}$ & $\begin{array}{l}0.518 \\
(0.300)\end{array}$ & $\begin{array}{l}-0.169 \\
(0.272)\end{array}$ & $\begin{array}{l}-0.262 \\
(0.344)\end{array}$ & $\begin{array}{l}0.414 \\
(0.258)\end{array}$ & $\begin{array}{l}0.547^{*} \\
(0.311)\end{array}$ & $\begin{array}{l}-0.266 \\
(0.288)\end{array}$ & $\begin{array}{l}-0.457 \\
(0.365)\end{array}$ \\
\hline Liquidity ratio $_{\mathrm{t}-1} \times$ Stress Proxy & $\begin{array}{l}-0.374 \\
(0.335)\end{array}$ & $\begin{array}{l}-1.163^{* *} \\
(0.470)\end{array}$ & $\begin{array}{l}-0.231 \\
(0.346)\end{array}$ & $\begin{array}{l}-0.473 \\
(0.463)\end{array}$ & $\begin{array}{l}-0.029 \\
(0.286)\end{array}$ & $\begin{array}{l}-0.175 \\
(0.289)\end{array}$ & $\begin{array}{l}0.373 \\
(0.253)\end{array}$ & $\begin{array}{l}0.530^{*} \\
(0.279)\end{array}$ \\
\hline Wholesale funding ${ }_{t-1}$ & $\begin{array}{l}-0.113 \\
(0.266)\end{array}$ & $\begin{array}{l}0.094 \\
(0.325)\end{array}$ & $\begin{array}{l}0.047 \\
(0.250)\end{array}$ & $\begin{array}{l}-0.176 \\
(0.270)\end{array}$ & $\begin{array}{l}0.047 \\
(0.270)\end{array}$ & $\begin{array}{l}0.260 \\
(0.307)\end{array}$ & $\begin{array}{l}0.095 \\
(0.253)\end{array}$ & $\begin{array}{l}-0.186 \\
(0.275)\end{array}$ \\
\hline Wholesale funding $\mathrm{t}_{\mathrm{t}-1} \times$ Stress Proxy & $\begin{array}{l}-0.150 \\
(0.446)\end{array}$ & $\begin{array}{l}-0.946 \\
(0.618)\end{array}$ & $\begin{array}{l}0.694 \\
(0.466)\end{array}$ & $\begin{array}{l}0.406 \\
(0.521)\end{array}$ & $\begin{array}{l}-0.439 * \\
(0.264)\end{array}$ & $\begin{array}{l}-0.471 \\
(0.325)\end{array}$ & $\begin{array}{l}0.107 \\
(0.233)\end{array}$ & $\begin{array}{l}0.205 \\
(0.331)\end{array}$ \\
\hline \multicolumn{9}{|l|}{ Solvency measures } \\
\hline NPL to Loans $\mathrm{t}_{\mathrm{t}-1}$ & $\begin{array}{l}-5.596 * \\
(3.307)\end{array}$ & $\begin{array}{l}-7.980^{* *} \\
(3.514)\end{array}$ & $\begin{array}{l}16.896 \\
(50.070)\end{array}$ & $\begin{array}{l}69.661 \\
(54.543)\end{array}$ & $\begin{array}{l}-7.300^{* *} \\
(3.560)\end{array}$ & $\begin{array}{l}-12.055^{* * *} \\
(3.784)\end{array}$ & $\begin{array}{l}39.127 \\
(66.654)\end{array}$ & $\begin{array}{l}83.262 \\
(68.388)\end{array}$ \\
\hline NPL to Loans $s_{t-1} \times$ Stress Proxy & $\begin{array}{l}19.813^{* * *} \\
(4.268)\end{array}$ & $\begin{array}{l}18.818^{*} \\
(9.902)\end{array}$ & $\begin{array}{l}11.891 \\
(98.681)\end{array}$ & $\begin{array}{l}5.370 \\
(123.245)\end{array}$ & $\begin{array}{l}8.929 * * \\
(3.766)\end{array}$ & $\begin{array}{l}18.003^{* * * *} \\
(6.534)\end{array}$ & $\begin{array}{l}-54.679 \\
(91.432)\end{array}$ & $\begin{array}{l}-26.762 \\
(90.795)\end{array}$ \\
\hline Capital ratio $_{\mathrm{t}-1}$ & $\begin{array}{l}2.369 * \\
(1.371)\end{array}$ & $\begin{array}{l}1.921 \\
(1.745)\end{array}$ & $\begin{array}{l}-3.000 \\
(1.409)\end{array}$ & $\begin{array}{l}-4.777 * * * \\
(1.578)\end{array}$ & $\begin{array}{l}2.023 \\
(1.274)\end{array}$ & $\begin{array}{l}1.041 \\
(1.966)\end{array}$ & $\begin{array}{l}-3.490^{* *} \\
(1.483)\end{array}$ & $\begin{array}{l}-5.471^{* * *} \\
(1.744)\end{array}$ \\
\hline Capital ratio $_{\mathrm{t}-1} \times$ Stress Proxy & $\begin{array}{l}0.903 \\
(1.694)\end{array}$ & $\begin{array}{l}1.147 \\
(2.269)\end{array}$ & $\begin{array}{l}2.066 \\
(2.379)\end{array}$ & $\begin{array}{l}0.437 \\
(2.365)\end{array}$ & $\begin{array}{l}1.380 \\
(1.389)\end{array}$ & $\begin{array}{l}2.911 \\
(2.103)\end{array}$ & $\begin{array}{l}1.199 \\
(1.049)\end{array}$ & $\begin{array}{l}1.675 \\
(1.772)\end{array}$ \\
\hline Risk-based capital ratio $_{t-1}$ & $\begin{array}{l}-1.256 \\
(1.115)\end{array}$ & $\begin{array}{l}-1.453 \\
(1.005)\end{array}$ & $\begin{array}{l}2.198^{* * *} \\
(0.721)\end{array}$ & $\begin{array}{l}1.363 * \\
(0.749)\end{array}$ & $\begin{array}{l}-0.996 \\
(1.120)\end{array}$ & $\begin{array}{l}-1.076 \\
(1.084)\end{array}$ & $\begin{array}{l}2.367 * * * \\
(0.691)\end{array}$ & $\begin{array}{l}1.803^{* *} \\
(0.726)\end{array}$ \\
\hline Risk-based capital ratio $\mathrm{t}_{\mathrm{t}-1} \times$ Stress Proxy & $\begin{array}{l}1.444 \\
(1.216)\end{array}$ & $\begin{array}{l}1.758 \\
(1.624)\end{array}$ & $\begin{array}{l}0.372 \\
(1.001)\end{array}$ & $\begin{array}{l}1.713 \\
(1.243)\end{array}$ & $\begin{array}{l}-0.972 \\
(1.237)\end{array}$ & $\begin{array}{l}-1.023 \\
(1.169)\end{array}$ & $\begin{array}{l}-0.162 \\
(0.579)\end{array}$ & $\begin{array}{l}-0.951 \\
(0.910)\end{array}$ \\
\hline Large Bank Indicator & $\begin{array}{l}-0.005 \\
(0.092)\end{array}$ & $\begin{array}{l}0.023 \\
(0.209)\end{array}$ & $\begin{array}{l}0.146 \\
(0.202)\end{array}$ & $\begin{array}{l}0.277 \\
(0.129)\end{array}$ & $\begin{array}{l}0.048 \\
(0.087)\end{array}$ & $\begin{array}{l}0.067 \\
(0.211)\end{array}$ & $\begin{array}{l}0.292 \\
(0.240)\end{array}$ & $\begin{array}{l}0.376^{* *} \\
(0.147)\end{array}$ \\
\hline Large Bank Indicator $\times$ Stress Proxy & $\begin{array}{l}-0.247^{* *} \\
(0.110)\end{array}$ & $\begin{array}{l}-0.096 \\
(0.180)\end{array}$ & $\begin{array}{l}0.430 \\
(0.282)\end{array}$ & $\begin{array}{l}0.631 \\
(0.265)\end{array}$ & $\begin{array}{l}-0.183^{* * *} \\
(0.070)\end{array}$ & $\begin{array}{l}-0.154^{*} \\
(0.081)\end{array}$ & $\begin{array}{l}-0.330 \\
(0.213)\end{array}$ & $\begin{array}{l}-0.134 \\
(0.148)\end{array}$ \\
\hline Bank Fixed Effects & Yes & Yes & Yes & Yes & Yes & Yes & Yes & Yes \\
\hline Observations & 51804 & 48393 & 51405 & 47326 & 51804 & 48393 & 51405 & 47326 \\
\hline $\mathrm{R}^{2}$ & 0.92 & 0.85 & 0.87 & 0.77 & 0.92 & 0.85 & 0.87 & 0.77 \\
\hline
\end{tabular}

The sample period of the regressions is from 1997 to 2009, using weekly Bank Rate Monitor data for the dependent variables.

All specifications are panel regressions with fixed effects for bank organizations and weekly time dummies. The reported $\mathrm{R}^{2}$ is the within $\mathrm{R}^{2}$.

All regressions control for the deposit-weighted geographic market deposit concentration (annual from Summary of Deposits).

Note that bank liquidity and solvency characteristics are from the quarterly Call Reports, and therefore $\mathrm{t}-1$ indicates the one quarter lag.

High nonperforming loan subset are those banks with a ratio of nonperforming loans (90 plus days) to loans above the median.

The standard errors used in calculating significance levels are clustered at the bank organization level.

See Appendix for variable definitions and details about bank panel. ***, **, * indicate $1 \%, 5 \%$, and $10 \%$ significance, respectively. 
Table A6. Impact of Lehman and TARP on Offered Deposit Rates

Weekly, Bank Rate Monitor (BRM): March 28, 2008 to February 27, 2009 (5 month period surrounding Lehman failure)

\begin{tabular}{|c|c|c|c|c|c|c|c|c|}
\hline Risk Measure: & $\begin{array}{l}(1) \\
24 \text { month CD } \\
\text { NPL }\end{array}$ & $\begin{array}{l}(2) \\
24 \text { month CD } \\
\text { NPL }\end{array}$ & $\begin{array}{l}(3) \\
60 \text { month CD } \\
\text { NPL }\end{array}$ & $\begin{array}{l}\text { (4) } \\
60 \text { month CD } \\
\text { NPL }\end{array}$ & $\begin{array}{l}\text { (5) } \\
24 \text { month CD } \\
\text { Unused } \\
\text { Commitments }\end{array}$ & $\begin{array}{l}(6) \\
24 \text { month CD } \\
\text { Unused } \\
\text { Commitments } \\
\end{array}$ & $\begin{array}{l}\text { (7) } \\
60 \text { month CD } \\
\text { Unused } \\
\text { Commitments } \\
\end{array}$ & $\begin{array}{l}(8) \\
60 \text { month CD } \\
\text { Unused } \\
\text { Commitments }\end{array}$ \\
\hline Risk Measure $_{\mathrm{t}-1} \times$ Pre-Lehman $(9 / 5,9 / 12)$ & $\begin{array}{l}6.165 \\
(5.692)\end{array}$ & $\begin{array}{l}3.902 \\
(4.382)\end{array}$ & $\begin{array}{l}9.560 \\
(7.249)\end{array}$ & $\begin{array}{l}6.652 \\
(4.925)\end{array}$ & $\begin{array}{l}0.538 \\
(0.373)\end{array}$ & $\begin{array}{l}0.805^{* *} \\
(0.320)\end{array}$ & $\begin{array}{l}0.901 * * \\
(0.438)\end{array}$ & $\begin{array}{l}1.018 * * * \\
(0.359)\end{array}$ \\
\hline Risk Measure $_{\mathrm{t}-1} \times$ Post-Lehman $(9 / 19,9 / 26)$ & $\begin{array}{l}10.610^{*} \\
(6.303)\end{array}$ & $\begin{array}{l}2.912 \\
(4.015)\end{array}$ & $\begin{array}{l}13.04^{* *} \\
(6.622)\end{array}$ & $\begin{array}{l}5.637 \\
(4.036)\end{array}$ & $\begin{array}{l}0.295 \\
(0.368)\end{array}$ & $\begin{array}{l}0.428 \\
(0.332)\end{array}$ & $\begin{array}{l}0.663 \\
(0.418)\end{array}$ & $\begin{array}{l}0.662^{*} \\
(0.359)\end{array}$ \\
\hline Risk Measure $_{\mathrm{t}-1} \times$ Post-TARP $(10 / 3,10 / 10)$ & $\begin{array}{l}11.934 \\
(7.645)\end{array}$ & $\begin{array}{l}3.708 \\
(4.674)\end{array}$ & $\begin{array}{l}11.032 \\
(9.220)\end{array}$ & $\begin{array}{l}8.990 \\
(7.642)\end{array}$ & $\begin{array}{l}0.346 \\
(0.413)\end{array}$ & $\begin{array}{l}0.023 \\
(0.324)\end{array}$ & $\begin{array}{l}0.881 \\
(0.563)\end{array}$ & $\begin{array}{l}0.614 \\
(0.477)\end{array}$ \\
\hline Pre-Lehman $(9 / 5,9 / 12)$ & $\begin{array}{l}0.243 * * * \\
(0.028)\end{array}$ & $\begin{array}{l}0.237 * * * \\
(0.023)\end{array}$ & $\begin{array}{l}0.275 * * * \\
(0.034)\end{array}$ & $\begin{array}{l}0.253^{* * *} \\
(0.029)\end{array}$ & $\begin{array}{l}0.159 * * \\
(0.072)\end{array}$ & $\begin{array}{l}0.089 \\
(0.060)\end{array}$ & $\begin{array}{l}0.123 \\
(0.085)\end{array}$ & $\begin{array}{l}0.070 \\
(0.068)\end{array}$ \\
\hline Post-Lehman $(9 / 19,9 / 26)$ & $\begin{array}{l}0.235 * * * \\
(0.029)\end{array}$ & $\begin{array}{l}0.243^{* * *} \\
(0.024)\end{array}$ & $\begin{array}{l}0.268^{* * *} \\
(0.032)\end{array}$ & $\begin{array}{l}0.267 * * * \\
(0.028)\end{array}$ & $\begin{array}{l}0.210^{* * *} \\
(0.073)\end{array}$ & $\begin{array}{l}0.165^{* *} \\
(0.064)\end{array}$ & $\begin{array}{l}0.171^{* *} \\
(0.085)\end{array}$ & $\begin{array}{l}0.152^{* *} \\
(0.071)\end{array}$ \\
\hline Post-TARP $(10 / 3,10 / 10)$ & $\begin{array}{l}0.258^{* * *} \\
(0.034)\end{array}$ & $\begin{array}{l}0.244^{* * *} \\
(0.026)\end{array}$ & $\begin{array}{l}0.318^{* * *} \\
(0.040)\end{array}$ & $\begin{array}{l}0.276^{* * *} \\
(0.030)\end{array}$ & $\begin{array}{l}0.208^{* *} \\
(0.083)\end{array}$ & $\begin{array}{l}0.257^{* * *} \\
(0.068)\end{array}$ & $\begin{array}{l}0.172^{*} \\
(0.103)\end{array}$ & $\begin{array}{l}0.186^{* *} \\
(0.088)\end{array}$ \\
\hline Bank Fixed Effects & No & Yes & No & Yes & No & Yes & No & Yes \\
\hline $\begin{array}{l}\text { Observations } \\
\mathrm{R}^{2}\end{array}$ & $\begin{array}{l}9092 \\
0.02\end{array}$ & $\begin{array}{l}9092 \\
0.06\end{array}$ & $\begin{array}{l}8333 \\
0.02\end{array}$ & $\begin{array}{l}8333 \\
0.06\end{array}$ & $\begin{array}{l}9092 \\
0.08\end{array}$ & $\begin{array}{l}9092 \\
0.07\end{array}$ & $\begin{array}{l}8333 \\
0.04\end{array}$ & $\begin{array}{l}8333 \\
0.06\end{array}$ \\
\hline
\end{tabular}

The sample period of the regressions is from March 28, 2008 to February 27, 2009 using weekly Bank Rate Monitor data.

This period corresponds to a five-month window surrounding the Lehman failure, similar to Afonso, Kovner and Schoar (2010).

The reported $R^{2}$ is the within $R^{2}$ for the panel fixed effects regressions in columns (2), (4), (6) and (8).

All regressions control for the deposit-weighted geographic market deposit concentration (annual from Summary of Deposits)

Note that bank liquidity and solvency characteristics are from the quarterly Call Reports, and therefore t- 1 indicates the one quarter lag.

The standard errors used in calculating significance levels are clustered at the bank organization level.

See Appendix for variable definitions and details about bank panel. ***, **, * indicate $1 \%, 5 \%$, and $10 \%$ significance, respectively. 
Table A7. Additional Measures: Controlling for Real Estate Loans and Securitization Exposure and for Market Equity Information

\begin{tabular}{|c|c|c|c|c|c|c|}
\hline & (1) & (2) & \multirow[b]{2}{*}{ (Reduc } & (4) & (5) & \multirow{2}{*}{$\begin{array}{l}\text { (6) } \\
\text { P Equity Data) }\end{array}$} \\
\hline & \multicolumn{2}{|c|}{$\begin{array}{l}\text { (Reduced Sample from 2006Q3 with } \\
\text { Available Securitization Data) }\end{array}$} & & ample of Bank & ith Available & \\
\hline & Large Time & Core & Large Time & Large Time & Core & Core \\
\hline \multicolumn{7}{|l|}{ Liquidity measures } \\
\hline Unused commitment ratiq -1 & $\begin{array}{l}0.131^{* * *} \\
(0.044)\end{array}$ & $\begin{array}{l}0.258^{* * *} \\
(0.035)\end{array}$ & $\begin{array}{l}0.132^{*} \\
(0.070)\end{array}$ & $\begin{array}{l}0.145^{* *} \\
(0.068)\end{array}$ & $\begin{array}{l}-0.092 \\
(0.064)\end{array}$ & $\begin{array}{l}-0.087 \\
(0.064)\end{array}$ \\
\hline Unused commitment ratiq $-1 \times$ Crisis 1 & $\begin{array}{l}0.047^{* *} \\
(0.023)\end{array}$ & $\begin{array}{l}-0.166^{* * *} \\
(0.023)\end{array}$ & $\begin{array}{l}-0.037 \\
(0.108)\end{array}$ & $\begin{array}{l}-0.040 \\
(0.109)\end{array}$ & $\begin{array}{l}-0.071 \\
(0.103)\end{array}$ & $\begin{array}{l}-0.067 \\
(0.103)\end{array}$ \\
\hline Unused commitment ratiq -1 × Crisis2 & $\begin{array}{l}-0.206 * * * \\
(0.036)\end{array}$ & $\begin{array}{l}-0.244 * * * \\
(0.027)\end{array}$ & $\begin{array}{l}-0.026 \\
(0.129)\end{array}$ & $\begin{array}{l}-0.039 \\
(0.128)\end{array}$ & $\begin{array}{l}-0.198^{*} \\
(0.115)\end{array}$ & $\begin{array}{l}-0.217^{*} \\
(0.114)\end{array}$ \\
\hline Liquidity ratiq -1 & $\begin{array}{l}0.026 \\
(0.030)\end{array}$ & $\begin{array}{l}0.026 \\
(0.025)\end{array}$ & $\begin{array}{l}-0.057 \\
(0.049)\end{array}$ & $\begin{array}{l}-0.045 \\
(0.047)\end{array}$ & $\begin{array}{l}-0.095^{* *} \\
(0.046)\end{array}$ & $\begin{array}{l}-0.068 \\
(0.043)\end{array}$ \\
\hline Liquidity ratiq $-1 \times$ Crisis 1 & $\begin{array}{l}-0.002 \\
(0.018)\end{array}$ & $\begin{array}{l}-0.039 * * \\
(0.017)\end{array}$ & $\begin{array}{l}0.001 \\
(0.082)\end{array}$ & $\begin{array}{l}-0.052 \\
(0.077)\end{array}$ & $\begin{array}{l}-0.080 \\
(0.085)\end{array}$ & $\begin{array}{l}-0.131 \\
(0.082)\end{array}$ \\
\hline Liquidity ratiq $_{-1} \times$ Crisis2 & $\begin{array}{l}-0.030 \\
(0.025)\end{array}$ & $\begin{array}{l}0.004 \\
(0.016)\end{array}$ & $\begin{array}{l}0.032 \\
(0.084)\end{array}$ & $\begin{array}{l}0.018 \\
(0.085)\end{array}$ & $\begin{array}{l}-0.051 \\
(0.066)\end{array}$ & $\begin{array}{l}-0.020 \\
(0.062)\end{array}$ \\
\hline Wholesale funding $-1_{-1}$ & $\begin{array}{l}0.021 \\
(0.031)\end{array}$ & $\begin{array}{l}-0.138^{* * *} \\
(0.027)\end{array}$ & $\begin{array}{l}0.141^{* * *} \\
(0.044)\end{array}$ & $\begin{array}{l}0.140^{* * *} \\
(0.044)\end{array}$ & $\begin{array}{l}-0.093^{* *} \\
(0.042)\end{array}$ & $\begin{array}{l}-0.085^{* *} \\
(0.042)\end{array}$ \\
\hline Wholesale funding $-1 \times$ Crisis 1 & $\begin{array}{l}0.010 \\
(0.018)\end{array}$ & $\begin{array}{l}0.053^{* * *} \\
(0.017)\end{array}$ & $\begin{array}{l}0.122^{*} \\
(0.065)\end{array}$ & $\begin{array}{l}0.070 \\
(0.061)\end{array}$ & $\begin{array}{l}0.159 * * * \\
(0.059)\end{array}$ & $\begin{array}{l}0.125 * * \\
(0.058)\end{array}$ \\
\hline Wholesale funding $-1 \times$ Crisis 2 & $\begin{array}{l}-0.083^{* * *} \\
(0.022)\end{array}$ & $\begin{array}{l}0.018 \\
(0.017)\end{array}$ & $\begin{array}{l}0.016 \\
(0.083)\end{array}$ & $\begin{array}{l}-0.045 \\
(0.086)\end{array}$ & $\begin{array}{l}0.147 * * \\
(0.072)\end{array}$ & $\begin{array}{l}0.093 \\
(0.069)\end{array}$ \\
\hline \multicolumn{7}{|l|}{ Solvency measures } \\
\hline NPL to Loans -1 & $\begin{array}{l}0.027 \\
(0.078)\end{array}$ & $\begin{array}{l}-0.189^{* * *} \\
(0.062)\end{array}$ & $\begin{array}{l}0.469 * * \\
(0.205)\end{array}$ & $\begin{array}{l}0.320^{*} \\
(0.193)\end{array}$ & $\begin{array}{l}0.281^{* *} \\
(0.122)\end{array}$ & $\begin{array}{l}0.178 \\
(0.131)\end{array}$ \\
\hline NPL to Loans $s_{t-1} \times$ Crisis 1 & $\begin{array}{l}-0.159 \\
(0.101)\end{array}$ & $\begin{array}{l}-0.008 \\
(0.055)\end{array}$ & $\begin{array}{l}-0.821 \\
(0.771)\end{array}$ & $\begin{array}{l}-0.690 \\
(0.780)\end{array}$ & $\begin{array}{l}0.427 \\
(0.708)\end{array}$ & $\begin{array}{l}0.498 \\
(0.706)\end{array}$ \\
\hline NPL to Loans $s_{-1} \times$ Crisis2 & $\begin{array}{l}0.222 * * * \\
(0.078)\end{array}$ & $\begin{array}{l}0.144^{* * *} \\
(0.045)\end{array}$ & $\begin{array}{l}-0.021 \\
(0.205)\end{array}$ & $\begin{array}{l}0.037 \\
(0.224)\end{array}$ & $\begin{array}{l}0.205 \\
(0.155)\end{array}$ & $\begin{array}{l}0.204 \\
(0.141)\end{array}$ \\
\hline Capital ratiq-1 & $\begin{array}{l}-0.296^{*} \\
(0.160)\end{array}$ & $\begin{array}{l}-0.241^{*} \\
(0.130)\end{array}$ & $\begin{array}{l}-0.427^{*} \\
(0.242)\end{array}$ & & $\begin{array}{l}-0.577 * * * \\
(0.150)\end{array}$ & \\
\hline Capital ratiq-1 $\times$ Crisis1 & $\begin{array}{l}0.194^{* *} \\
(0.086)\end{array}$ & $\begin{array}{l}-0.017 \\
(0.098)\end{array}$ & $\begin{array}{l}0.978^{* * *} \\
(0.293)\end{array}$ & & $\begin{array}{l}0.393^{* *} \\
(0.185)\end{array}$ & \\
\hline Capital ratiq -1 × Crisis2 & $\begin{array}{l}-0.105 \\
(0.133)\end{array}$ & $\begin{array}{l}-0.043 \\
(0.088)\end{array}$ & $\begin{array}{l}0.821 * * \\
(0.374)\end{array}$ & & $\begin{array}{l}0.262 \\
(0.229)\end{array}$ & \\
\hline Risk-based capital ratiq-1 & $\begin{array}{l}-0.195 * * \\
(0.083)\end{array}$ & $\begin{array}{l}-0.036 \\
(0.077)\end{array}$ & $\begin{array}{l}-0.035 \\
(0.169)\end{array}$ & $\begin{array}{l}-0.097 \\
(0.149)\end{array}$ & $\begin{array}{l}-0.006 \\
(0.122)\end{array}$ & $\begin{array}{l}-0.171 \\
(0.120)\end{array}$ \\
\hline Risk-based capital ratiq -1 × Crisis1 & $\begin{array}{l}-0.014 \\
(0.047)\end{array}$ & $\begin{array}{l}0.051 \\
(0.065)\end{array}$ & $\begin{array}{l}-0.372 \\
(0.393)\end{array}$ & $\begin{array}{l}-0.008 \\
(0.359)\end{array}$ & $\begin{array}{l}-0.361 \\
(0.223)\end{array}$ & $\begin{array}{l}0.115 \\
(0.255)\end{array}$ \\
\hline Risk-based capital ratiq -1 × Crisis2 & $\begin{array}{l}-0.011 \\
(0.109)\end{array}$ & $\begin{array}{l}0.102^{* *} \\
(0.052)\end{array}$ & $\begin{array}{l}-0.590 * \\
(0.357)\end{array}$ & $\begin{array}{l}-0.250 \\
(0.337)\end{array}$ & $\begin{array}{l}-0.563^{*} \\
(0.306)\end{array}$ & $\begin{array}{l}-0.039 \\
(0.278)\end{array}$ \\
\hline Large Bank Indicator & $\begin{array}{l}-0.204 \\
(0.137)\end{array}$ & $\begin{array}{l}-0.026 \\
(0.043)\end{array}$ & $\begin{array}{l}-0.037 \\
(0.035)\end{array}$ & $\begin{array}{l}-0.050 \\
(0.033)\end{array}$ & $\begin{array}{l}-0.019 \\
(0.034)\end{array}$ & $\begin{array}{l}-0.031 \\
(0.034)\end{array}$ \\
\hline Large Bank Indicator $\times$ Crisis1 & $\begin{array}{l}-0.054^{*} \\
(0.029)\end{array}$ & $\begin{array}{l}-0.045^{* *} \\
(0.018)\end{array}$ & $\begin{array}{l}-0.034 \\
(0.045)\end{array}$ & $\begin{array}{l}-0.030 \\
(0.044)\end{array}$ & $\begin{array}{l}-0.049 * * \\
(0.021)\end{array}$ & $\begin{array}{l}-0.046^{* *} \\
(0.022)\end{array}$ \\
\hline Large Bank Indicator $\times$ Crisis2 & $\begin{array}{l}-0.032 \\
(0.024)\end{array}$ & $\begin{array}{l}0.007 \\
(0.021)\end{array}$ & $\begin{array}{l}-0.033 \\
(0.032)\end{array}$ & $\begin{array}{l}-0.035 \\
(0.031)\end{array}$ & $\begin{array}{l}-0.026 \\
(0.021)\end{array}$ & $\begin{array}{l}-0.032 \\
(0.022)\end{array}$ \\
\hline \multicolumn{7}{|l|}{ Real estate loan exposure and securitization } \\
\hline Real Estate Loan Share ${ }_{-1}$ & $\begin{array}{l}-0.037 \\
(0.045)\end{array}$ & $\begin{array}{l}-0.062^{*} \\
(0.033)\end{array}$ & & & & \\
\hline Real Estate Loan Share ${ }_{-1} \times$ Crisis1 & $\begin{array}{l}-0.004 \\
(0.011)\end{array}$ & $\begin{array}{l}0.005 \\
(0.010)\end{array}$ & & & & \\
\hline Real Estate Loan Share ${ }_{-1} \times$ Crisis2 & $\begin{array}{l}0.030^{* *} \\
(0.015)\end{array}$ & $\begin{array}{l}0.064^{* * *} \\
(0.010)\end{array}$ & & & & \\
\hline Residential Mortgages Sold -1 & $\begin{array}{l}-0.035 \\
(0.026)\end{array}$ & $\begin{array}{l}-0.030 \\
(0.029)\end{array}$ & & & & \\
\hline Residential Mortgages Sold $\mathrm{d}_{-1} \times$ Crisis1 & $\begin{array}{l}0.026 \\
(0.043)\end{array}$ & $\begin{array}{l}0.058^{* *} \\
(0.025)\end{array}$ & & & & \\
\hline Residential Mortgages Sold $-1 \times$ Crisis2 & $\begin{array}{l}0.041 \\
(0.037)\end{array}$ & $\begin{array}{l}-0.018 \\
(0.025)\end{array}$ & & & & \\
\hline \multicolumn{7}{|l|}{ Market equity measures } \\
\hline Volatility of Daily Equity Returns $\$_{1}$ & & & $\begin{array}{l}0.273 \\
(0.174)\end{array}$ & $\begin{array}{l}0.265 \\
(0.165)\end{array}$ & $\begin{array}{l}0.108 \\
(0.149)\end{array}$ & $\begin{array}{l}0.130 \\
(0.148)\end{array}$ \\
\hline Volatility of Daily Equity Return $\S_{1} \times$ Crisis 1 & & & $\begin{array}{l}0.672 \\
(0.450)\end{array}$ & $\begin{array}{l}0.396 \\
(0.432)\end{array}$ & & $\begin{array}{l}1.061^{* *} \\
(0.425)\end{array}$ \\
\hline Volatility of Daily Equity Return $\$_{1} \times$ Crisis2 & & & $\begin{array}{l}0.548^{* *} \\
(0.252)\end{array}$ & $\begin{array}{l}0.344 \\
(0.268)\end{array}$ & $\begin{array}{l}0.249 \\
(0.200)\end{array}$ & $\begin{array}{l}0.017 \\
(0.189)\end{array}$ \\
\hline Equity Return & & & $\begin{array}{l}0.000 \\
(0.004)\end{array}$ & & $\begin{array}{l}-0.005 \\
(0.004)\end{array}$ & \\
\hline Equity Return $_{-1} \times$ Crisis 1 & & & $\begin{array}{l}-0.012 \\
(0.033)\end{array}$ & & $\begin{array}{l}-0.064 * * * \\
(0.021)\end{array}$ & \\
\hline Equity Return $-1_{1} \times$ Crisis2 & & & $\begin{array}{l}-0.024 \\
(0.017)\end{array}$ & & $\begin{array}{l}-0.015 \\
(0.012)\end{array}$ & \\
\hline Quasi market capital to asset ratiq-1 & & & & $\begin{array}{l}-0.311 * * * \\
(0.088)\end{array}$ & & $\begin{array}{l}-0.258^{* * *} \\
(0.069)\end{array}$ \\
\hline Quasi market capital to asset ratiq $-1 \times$ Crisis1 & & & & $\begin{array}{l}0.085 \\
(0.105)\end{array}$ & & $\begin{array}{l}-0.082 \\
(0.110)\end{array}$ \\
\hline Quasi market capital to asset ratiq $-1 \times$ Crisis2 & & & & $\begin{array}{l}-0.047 \\
(0.172)\end{array}$ & & $\begin{array}{l}-0.228 * * \\
(0.094)\end{array}$ \\
\hline Bank Fixed Effects & Yes & Yes & Yes & Yes & Yes & Yes \\
\hline Observations & 48535 & 48628 & 20055 & 20055 & 20084 & 20084 \\
\hline $\mathrm{R}^{2}$ & 0.73 & 0.81 & 0.77 & 0.77 & 0.88 & 0.88 \\
\hline
\end{tabular}


Table A8. Additional Measures: Maturity Structure of Large-Time Deposits

\begin{tabular}{|c|c|c|c|}
\hline & $\begin{array}{l}1) \\
\text { Large Time Rate }\end{array}$ & $\begin{array}{l}(2) \\
\text { Core Rate }\end{array}$ & $\begin{array}{l}\text { (3) } \\
\text { Share of Large } \\
\text { Time Deposits } \\
\text { Maturing in One } \\
\text { Year or Less }\end{array}$ \\
\hline \multicolumn{4}{|l|}{ Liquidity measures } \\
\hline Unused commitment ratio ${ }_{\mathrm{t}-1}$ & $\begin{array}{l}0.038 \\
(0.025)\end{array}$ & $\begin{array}{l}-0.063^{* * *} \\
(0.019)\end{array}$ & $\begin{array}{l}-0.014 \\
(0.018)\end{array}$ \\
\hline Unused commitment ratio $\mathrm{t}_{\mathrm{t}-1} \times$ Crisis1 & $\begin{array}{l}0.065^{* *} \\
(0.030)\end{array}$ & $\begin{array}{l}-0.036 \\
(0.025)\end{array}$ & $\begin{array}{l}0.060^{* *} \\
(0.024)\end{array}$ \\
\hline Unused commitment ratio $\mathrm{t}_{\mathrm{t}-1} \times$ Crisis2 & $\begin{array}{l}-0.146^{* * *} \\
(0.035)\end{array}$ & $\begin{array}{l}-0.173^{* * *} \\
(0.026)\end{array}$ & $\begin{array}{l}0.040^{*} \\
(0.023)\end{array}$ \\
\hline Liquidity ratio ${ }_{\mathrm{t}-1}$ & $\begin{array}{l}-0.027^{*} \\
(0.016)\end{array}$ & $\begin{array}{l}-0.025^{* *} \\
(0.012)\end{array}$ & $\begin{array}{l}0.060^{* * *} \\
(0.012)\end{array}$ \\
\hline Liquidity ratio $\mathrm{t}_{\mathrm{t}-1} \times$ Crisis 1 & $\begin{array}{l}-0.009 \\
(0.020)\end{array}$ & $\begin{array}{l}-0.100^{* * *} \\
(0.017)\end{array}$ & $\begin{array}{l}-0.148 * * * \\
(0.015)\end{array}$ \\
\hline Liquidity ratio $_{\mathrm{t}-1} \times$ Crisis2 & $\begin{array}{l}-0.048^{* *} \\
(0.023)\end{array}$ & $\begin{array}{l}-0.083^{* * *} \\
(0.016)\end{array}$ & $\begin{array}{l}-0.061^{* * *} \\
(0.015)\end{array}$ \\
\hline Wholesale funding $\mathrm{t}_{-1}$ & $\begin{array}{l}0.114 * * * \\
(0.017)\end{array}$ & $\begin{array}{l}-0.081^{* * *} \\
(0.017)\end{array}$ & $\begin{array}{l}-0.025 \\
(0.017)\end{array}$ \\
\hline Wholesale funding ${ }_{t-1} \times$ Crisis1 & $\begin{array}{l}0.014 \\
(0.018)\end{array}$ & $\begin{array}{l}0.117^{* * *} \\
(0.020)\end{array}$ & $\begin{array}{l}-0.052^{* * *} \\
(0.016)\end{array}$ \\
\hline Wholesale funding $\mathrm{t}_{\mathrm{t}-1} \times$ Crisis2 & $\begin{array}{l}-0.053^{* *} \\
(0.022)\end{array}$ & $\begin{array}{l}0.079 * * * \\
(0.019)\end{array}$ & $\begin{array}{l}0.008 \\
(0.016)\end{array}$ \\
\hline \multicolumn{4}{|l|}{ Solvency measures } \\
\hline NPL to Loans & $\begin{array}{l}0.207^{* * *} \\
(0.060)\end{array}$ & $\begin{array}{l}0.028 \\
(0.046)\end{array}$ & $\begin{array}{l}0.053 \\
(0.045)\end{array}$ \\
\hline NPL to Loans $_{t-1} \times$ Crisis1 & $\begin{array}{l}-0.071 \\
(0.109)\end{array}$ & $\begin{array}{l}0.251^{* * *} \\
(0.090)\end{array}$ & $\begin{array}{l}-0.053 \\
(0.084)\end{array}$ \\
\hline NPL to Loans $\mathrm{t}_{\mathrm{t}-1} \times$ Crisis2 & $\begin{array}{l}0.330 * * * \\
(0.077)\end{array}$ & $\begin{array}{l}0.295 * * * \\
(0.058)\end{array}$ & $\begin{array}{l}0.032 \\
(0.062)\end{array}$ \\
\hline Capital ratio ${ }_{t-1}$ & $\begin{array}{l}-0.225^{* *} \\
(0.108)\end{array}$ & $\begin{array}{l}-0.384 * * * \\
(0.080)\end{array}$ & $\begin{array}{l}0.173^{* *} \\
(0.072)\end{array}$ \\
\hline Capital ratio $_{\mathrm{t}-1} \times$ Crisis 1 & $\begin{array}{l}0.368^{* * *} \\
(0.086)\end{array}$ & $\begin{array}{l}0.175 \\
(0.112)\end{array}$ & $\begin{array}{l}-0.255^{* * *} \\
(0.075)\end{array}$ \\
\hline Capital ratio ${ }_{\mathrm{t}-1} \times$ Crisis2 & $\begin{array}{l}0.101 \\
(0.125)\end{array}$ & $\begin{array}{l}0.011 \\
(0.078)\end{array}$ & $\begin{array}{l}-0.157^{* *} \\
(0.078)\end{array}$ \\
\hline Risk-based capital ratio ${ }_{\mathrm{t}-1}$ & $\begin{array}{l}0.018 \\
(0.058)\end{array}$ & $\begin{array}{l}-0.118 * * * \\
(0.026)\end{array}$ & $\begin{array}{l}-0.087 * * * \\
(0.027)\end{array}$ \\
\hline Risk-based capital ratio $\mathrm{t}_{\mathrm{t}-1} \times$ Crisis1 & $\begin{array}{l}-0.168 * * * \\
(0.051)\end{array}$ & $\begin{array}{l}-0.110^{* *} \\
(0.053)\end{array}$ & $\begin{array}{l}0.131^{* * *} \\
(0.043)\end{array}$ \\
\hline Risk-based capital ratio ${ }_{\mathrm{t}-1} \times$ Crisis2 & $\begin{array}{l}-0.149 \\
(0.100)\end{array}$ & $\begin{array}{l}0.054 \\
(0.041)\end{array}$ & $\begin{array}{l}0.063 \\
(0.045)\end{array}$ \\
\hline Large Bank Indicator & $\begin{array}{l}-0.009 \\
(0.037)\end{array}$ & $\begin{array}{l}0.009 \\
(0.024)\end{array}$ & $\begin{array}{l}0.012 \\
(0.019)\end{array}$ \\
\hline Large Bank Indicator $\times$ Crisis1 & $\begin{array}{l}-0.046 \\
(0.034)\end{array}$ & $\begin{array}{l}-0.081^{* * *} \\
(0.018)\end{array}$ & $\begin{array}{l}0.013 \\
(0.012)\end{array}$ \\
\hline Large Bank Indicator $\times$ Crisis2 & $\begin{array}{l}-0.042 \\
(0.026)\end{array}$ & $\begin{array}{l}-0.013 \\
(0.017)\end{array}$ & $\begin{array}{l}-0.032 * * \\
(0.016)\end{array}$ \\
\hline \multicolumn{4}{|l|}{ Maturity Structure } \\
\hline Share of large-time deposits maturing in 1 year $_{\mathrm{t}-1}$ & $\begin{array}{l}-0.174^{* * *} \\
(0.008)\end{array}$ & $\begin{array}{l}-0.010^{*} \\
(0.005)\end{array}$ & \\
\hline Share of large-time deposits maturing in 1 year $_{\mathrm{t}-1} \times$ Crisis 1 & $\begin{array}{l}0.250^{* * *} \\
(0.014)\end{array}$ & $\begin{array}{l}0.060^{* * *} \\
(0.010)\end{array}$ & \\
\hline Share of large-time deposits maturing in 1 year $_{t-1} \times$ Crisis2 & $\begin{array}{l}-0.073^{* * *} \\
(0.014)\end{array}$ & $\begin{array}{l}-0.020^{*} \\
(0.010)\end{array}$ & \\
\hline Bank Fixed Effects & Yes & Yes & Yes \\
\hline Observations & 163450 & 163167 & 166117 \\
\hline $\mathrm{R}^{2}$ & 0.78 & 0.89 & 0.21 \\
\hline \multicolumn{4}{|c|}{$\begin{array}{l}\text { The sample period of the regressions is from } 1997 \text { to } 2009 \text { (maturity information available from 1997), using quarterly Call Re } \\
\text { All specifications are panel regressions with fixed effects for bank organizations and quarterly time dummies. } \\
\text { The reported } \mathrm{R}^{2} \text { is the within } \mathrm{R}^{2} \text {. All regressions control for District time trends and for the deposit-weighted geographic mark } \\
\text { deposit concentration (annual from Summary of Deposits). Crisis } 1 \text { is a dummy variable equal to } 1 \text { from } 2007 \mathrm{Q} 3 \text { to 2008Q2, } \\
\text { and Crisis } 2 \text { is a dummy variable equal to } 1 \text { from } 2008 \mathrm{Q} 3 \text { to 2009Q2. } \\
\text { The standard errors used in calculating significance levels are clustered at the bank organization level. }\end{array}$} \\
\hline
\end{tabular}


Table A9. Robustness Check: Pre-Crisis Values of Controls

\begin{tabular}{|c|c|c|c|}
\hline & $\begin{array}{l}\text { (1) } \\
\text { Large Time Rate }\end{array}$ & $\begin{array}{l}(2) \\
\text { Core Rate }\end{array}$ & $\begin{array}{l}\text { (3) } \\
\Delta \text { Deposits/ } \\
\text { Assets }_{\mathrm{t}-1}\end{array}$ \\
\hline \multicolumn{4}{|l|}{ Liquidity measures } \\
\hline Unused commitment ratio -1 & $\begin{array}{l}0.023 \\
(0.027)\end{array}$ & $\begin{array}{l}-0.082 * * * \\
(0.022)\end{array}$ & $\begin{array}{l}0.033^{* * *} \\
(0.004)\end{array}$ \\
\hline Unused commitment ratiq ${ }_{-1} \times$ Crisis 1 & $\begin{array}{l}0.149 * * * \\
(0.029)\end{array}$ & $\begin{array}{l}-0.015 \\
(0.024)\end{array}$ & $\begin{array}{l}-0.003 \\
(0.006)\end{array}$ \\
\hline Unused commitment ratiq ${ }_{-1} \times$ Crisis2 & $\begin{array}{l}-0.080^{* *} \\
(0.035)\end{array}$ & $\begin{array}{l}-0.096 * * * \\
(0.025)\end{array}$ & $\begin{array}{l}0.008 \\
(0.006)\end{array}$ \\
\hline Liquidity ratio ${ }_{\mathrm{t}-1}$ & $\begin{array}{l}-0.045^{* * *} \\
(0.017)\end{array}$ & $\begin{array}{l}-0.049 * * * \\
(0.013)\end{array}$ & $\begin{array}{l}-0.079 * * * \\
(0.002)\end{array}$ \\
\hline Liquidity ratio $_{\mathrm{t}-1} \times$ Crisis1 & $\begin{array}{l}0.005 \\
(0.021)\end{array}$ & $\begin{array}{l}-0.121^{* * *} \\
(0.019)\end{array}$ & $\begin{array}{l}0.020^{* * *} \\
(0.004)\end{array}$ \\
\hline Liquidity ratio $_{\mathrm{t}-1} \times$ Crisis2 & $\begin{array}{l}-0.073^{* * *} \\
(0.021)\end{array}$ & $\begin{array}{l}-0.093^{* * *} \\
(0.017)\end{array}$ & $\begin{array}{l}0.010^{* *} \\
(0.004)\end{array}$ \\
\hline Wholesale funding ${ }_{t-1}$ & $\begin{array}{l}0.142^{* * *} \\
(0.019)\end{array}$ & $\begin{array}{l}-0.044^{* *} \\
(0.018)\end{array}$ & $\begin{array}{l}0.043^{* * *} \\
(0.003)\end{array}$ \\
\hline Wholesale funding $t_{-1} \times$ Crisis1 & $\begin{array}{l}0.034^{*} \\
(0.019)\end{array}$ & $\begin{array}{l}0.135^{* * *} \\
(0.020)\end{array}$ & $\begin{array}{l}-0.010^{* * *} \\
(0.004)\end{array}$ \\
\hline Wholesale funding $\mathrm{t}_{-1} \times$ Crisis2 & $\begin{array}{l}-0.034 \\
(0.023)\end{array}$ & $\begin{array}{l}0.134 * * * \\
(0.020)\end{array}$ & $\begin{array}{l}-0.016^{* * *} \\
(0.004)\end{array}$ \\
\hline \multicolumn{4}{|l|}{ Solvency measures } \\
\hline NPL to Loans $\mathrm{t}_{\mathrm{t}-1}$ & $\begin{array}{l}0.136 \\
(0.088)\end{array}$ & $\begin{array}{l}0.024 \\
(0.061)\end{array}$ & $\begin{array}{l}-0.212^{* * *} \\
(0.024)\end{array}$ \\
\hline NPL to Loans t-1 $_{1} \times$ Crisis 1 & $\begin{array}{l}-0.341^{*} \\
(0.176)\end{array}$ & $\begin{array}{l}0.182 * * \\
(0.075)\end{array}$ & $\begin{array}{l}-0.014 \\
(0.018)\end{array}$ \\
\hline NPL to Loans $\mathrm{t}_{\mathrm{t}-1} \times$ Crisis2 & $\begin{array}{l}0.299 \\
(0.191)\end{array}$ & $\begin{array}{l}0.209 * * * \\
(0.075)\end{array}$ & $\begin{array}{l}0.014 \\
(0.030)\end{array}$ \\
\hline Capital ratio ${ }_{\mathrm{t}-1}$ & $\begin{array}{l}-0.182 * \\
(0.108)\end{array}$ & $\begin{array}{l}-0.498^{* * *} \\
(0.095)\end{array}$ & $\begin{array}{l}0.183^{* * *} \\
(0.017)\end{array}$ \\
\hline Capital ratio $_{\mathrm{t}-1} \times$ Crisis 1 & $\begin{array}{l}0.394 * * * \\
(0.083)\end{array}$ & $\begin{array}{l}0.204^{*} \\
(0.117)\end{array}$ & $\begin{array}{l}-0.014 \\
(0.016)\end{array}$ \\
\hline Capital ratio $_{\mathrm{t}-1} \times$ Crisis2 & $\begin{array}{l}0.192 * * \\
(0.092)\end{array}$ & $\begin{array}{l}0.211^{* * *} \\
(0.075)\end{array}$ & $\begin{array}{l}-0.025 \\
(0.017)\end{array}$ \\
\hline Risk-based capital ratio $\mathrm{t}_{\mathrm{t}-\mathrm{1}}$ & $\begin{array}{l}0.020 \\
(0.055)\end{array}$ & $\begin{array}{l}-0.002 \\
(0.032)\end{array}$ & $\begin{array}{l}-0.007^{* *} \\
(0.003)\end{array}$ \\
\hline Risk-based capital ratio $_{\mathrm{t}-1} \times$ Crisis1 & $\begin{array}{l}-0.160^{* * *} \\
(0.050)\end{array}$ & $\begin{array}{l}-0.056 \\
(0.062)\end{array}$ & $\begin{array}{l}0.032 * * * \\
(0.009)\end{array}$ \\
\hline Risk-based capital ratio $_{\mathrm{t}-1} \times$ Crisis2 & $\begin{array}{l}-0.055 \\
(0.042)\end{array}$ & $\begin{array}{l}0.025 \\
(0.036)\end{array}$ & $\begin{array}{l}0.035^{* * * *} \\
(0.010)\end{array}$ \\
\hline Large Bank Indicator & $\begin{array}{l}-0.020 \\
(0.032)\end{array}$ & $\begin{array}{l}0.005 \\
(0.026)\end{array}$ & $\begin{array}{l}-0.006^{*} \\
(0.003)\end{array}$ \\
\hline Large Bank Indicator $\times$ Crisis1 & $\begin{array}{l}-0.044 \\
(0.036)\end{array}$ & $\begin{array}{l}-0.081^{* * *} \\
(0.019)\end{array}$ & $\begin{array}{l}0.009 * * * \\
(0.003)\end{array}$ \\
\hline Large Bank Indicator $\times$ Crisis2 & $\begin{array}{l}-0.067 * * \\
(0.028)\end{array}$ & $\begin{array}{l}-0.045^{* *} \\
(0.022)\end{array}$ & $\begin{array}{l}-0.002 \\
(0.005)\end{array}$ \\
\hline Bank Fixed Effects & Yes & Yes & Yes \\
\hline Observations & 175611 & 175638 & 176080 \\
\hline $\mathrm{R}^{2}$ & 0.76 & 0.89 & 0.06 \\
\hline
\end{tabular}

The sample period of the regressions is from 1996 to 2009, using quarterly Call Report data.

All specifications are panel regressions with fixed effects for bank organizations and quarterly time dummies.

The reported $\mathrm{R}^{2}$ is the within $\mathrm{R}^{2}$. All regressions control for District time trends and for the deposit-weighted geographic market deposit concentration (annual from Summary of Deposits). Crisis 1 is a dummy variable equal to 1 from 2007Q3 to 2008Q2, and Crisis 2 is a dummy variable equal to 1 from 2008Q3 to 2009Q2.

Note that the liquidity and solvency measures in this table are taken at their pre-crisis values. That is, we include lagged values of these measures up to 2007:Q2 and from then on, the value of these variables as of 2007:Q2 are used.

The standard errors used in calculating significance levels are clustered at the bank organization level.

See Appendix for variable definitions and details about bank panel. ***, **, * indicate $1 \%$, 5\%, and 10\% significance, respectively. 